ESCOLA POLITÉCNICA DA UNIVERSIDADE DE SÃO PAULO

Departamento de Engenharia de Estruturas e Geotécnica

Programa de Pós-Graduação em Engenharia Civil

Subárea de Engenharia Geotécnica

UTILIZAÇÃO DE MISTURA DE SOLO SAPROLÍTICO COM BENTONITA NA CONSTRUÇÃO DE REVESTIMENTO DE FUNDO DE ATERROS SANITÁRIOS

VALÉRIA SOARES

Dissertação apresentada à Escola Politécnica da Universidade de São Paulo para obtenção do título de Mestre em Engenharia.

SÃO PAULO 
ESCOLA POLITÉCNICA DA UNIVERSIDADE DE SÃO PAULO

Departamento de Engenharia de Estruturas e Geotécnica

Programa de Pós-Graduação em Engenharia Civil

Subárea de Engenharia Geotécnica

\section{UTILIZAÇÃO DE MISTURA DE SOLO SAPROLÍTICO COM BENTONITA NA CONSTRUÇÃO DE REVESTIMENTO DE FUNDO DE ATERROS SANITÁRIOS}

\section{VALÉRIA SOARES}

Dissertação apresentada à Escola Politécnica da Universidade de São Paulo para obtenção do título de Mestre em Engenharia.

Linha de pesquisa: Geotecnia Ambiental -

Disposição de Resíduos e Rejeitos

Orientadora: Profa. Maria Eugenia Gimenez Boscov

SÃO PAULO

2012 
Autorizo a reprodução e divulgação total ou parcial deste trabalho, por qualquer meio convencional ou eletrônico, para fins acadêmicos e de pesquisa, desde que citada a fonte.

Este exemplar foi revisado e alterado em relação à versão original, sob responsabilidade única do autor e com anuência de seu orientador.

São Paulo,18, abril de 2012.

Assinatura do autor:

Assinatura do orientador:

FICHA CATALOGRÁFICA

Soares, Valéria

Utilização de mistura de solo saprolítico com bentonita na construção de revestimento de fundo de aterros sanitários / V. Soares. -- ed.rev. -- São Paulo, 2012.

$118 \mathrm{p}$.

Dissertação (Mestrado) - Escola Politécnica da Universidade de São Paulo. Departamento de Engenharia de Estruturas e Geotécnica.

1. Aterros sanitários 2. Solo tropical 3. Bentonita 4. Chorume 5. Impermeabilização I. Universidade de São Paulo. Escola Politécnica. Departamento de Engenharia de Estruturas e Geotécnica II. t. 
Soares, V.. Utilização de mistura de solo saprolítico com bentonita na construção de revestimento de fundo de aterros. Dissertação apresentada à Escola Politécnica da Universidade de São Paulo para obtenção do título de Mestre em Engenharia Civil.

Aprovado em:

$$
\text { Banca Examinadora }
$$

Prof. Dra. Maria Eugenia Gimenez Boscov (orientadora)

Escola Politécnica da Universidade de São Paulo

Julgamento:

$$
\text { Prof. Dr. Edmundo Rogerio Esquivel }
$$

Escola de Engenharia de São Carlos da Universidade de São Paulo

Julgamento:

$$
\begin{gathered}
\text { Prof. Dra. Izabel Christina d'Almeida Duarte de Azevedo } \\
\text { Universidade Federal de Viçosa }
\end{gathered}
$$

Julgamento: 
Dedicatóría

Aos

Meus pais: Mami e Papi (in memoriam)

Meus irmãos: Marco e Patrícia

Meu noivo: Claudinho 


\section{Agradecimentos}

À Deus, por tudo ser como é.

À minha querida orientadora, Maria Eugênia, pela dedicação, confiança e paciência. Ao corpo docente do PEF, principalmente ao professor Carlos Pinto, pelo exemplo de dedicação, disposição e entusiasmo;

Às professoras Izabel e Heloísa por suas observações durante a qualificação.

Ao prof. Milton Vargas (in memoriam) por seu brilhantismo, simplicidade e obra.

Ao Toninho e ao Joaquim pela valorosa colaboração durante os ensaios.

Às empresas Bentonit União Nordeste Ind. e Com., Central de Tratamento de Resíduos

Caieiras (CTR-Caieiras), pelo fornecimento da bentonita, do solo e do percolado utilizado nos estudos.

À Mônica Stuermer (Mackenzie) pela orientação nos ensaios de expansão.

Aos colegas da Poli que fizeram parte desta fase e ajudaram a transformar os momentos de tensão em lembranças carinhosas.

Aos ex-bolsistas de iniciação científica (Felipe, Maurício e Renato) e aos "quase bolsistas" (Thiago Zanon e André Marguti) pela cooperação e pelas boas risadas.

Aos meus companheiros de trabalho da CETESB-Pinheiros pelo incentivo e orientação, em especial ao Jorge Ogata, Thiago Campi, João Fuzaro, Cristiano Iwai, Sidney Shinke, Fernando A. Wolmer e Patrícia S.M.B..

Aos meus sobrinhos e afilhado: Henry, Kaká, Maria Clara e Cauê, pela alegria que vocês me fazem sentir.

Aos meus familiares e amigos, pelo incentivo, amor e compreensão, que me fortalece e me faz feliz. 
"O que importa na vida não é o ponto de partida, mas a caminhada. Caminhando e semeando, no fim terás o que colher." (Cora Coralina) 
SUMÁRIO

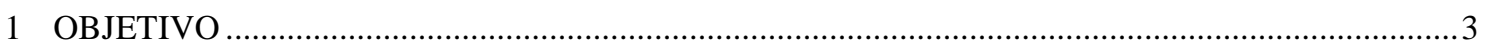

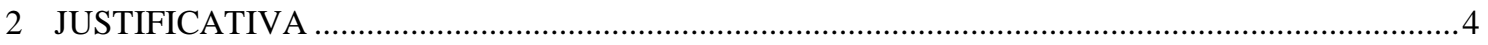

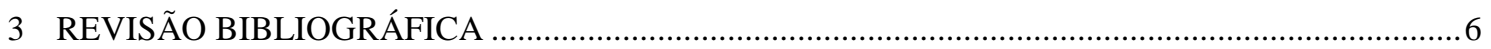

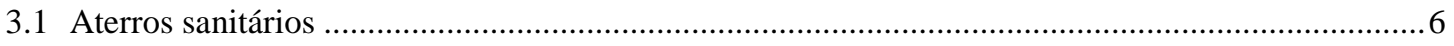

3.2 Impermeabilização de fundo de aterros sanitários ........................................................................

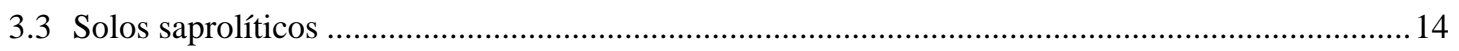

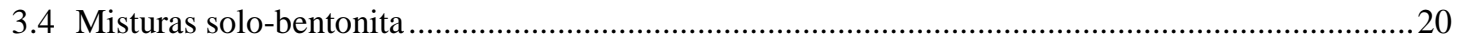

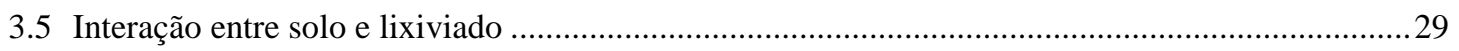

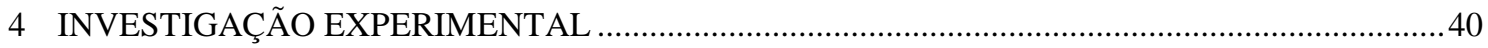

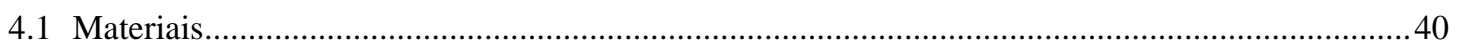

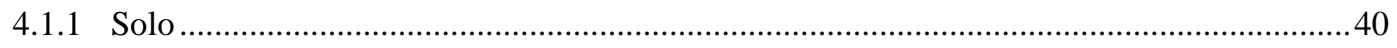

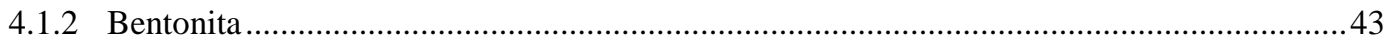

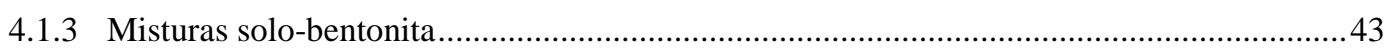

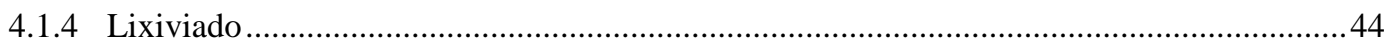

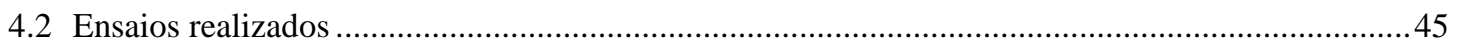

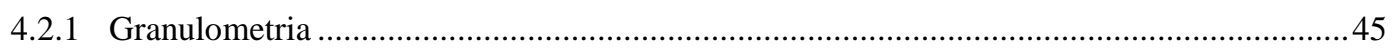

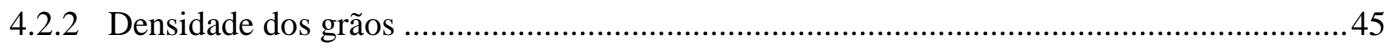

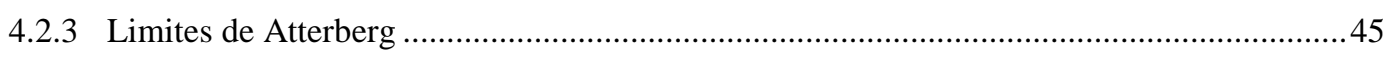

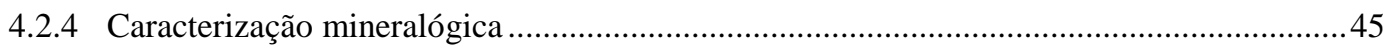

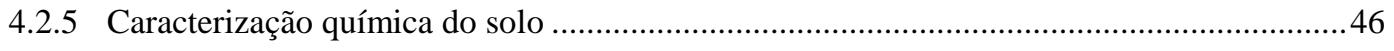

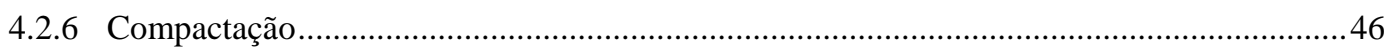

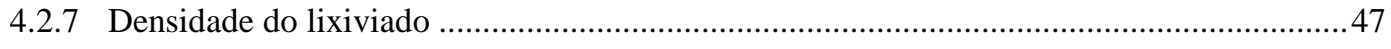

4.2.8 Permeabilidade de carga constante ………………........................................................

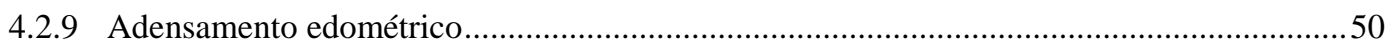

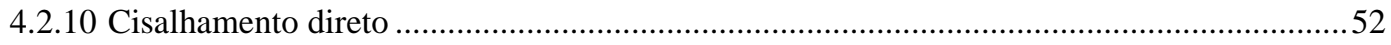

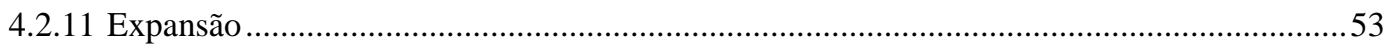

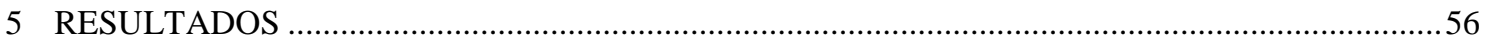

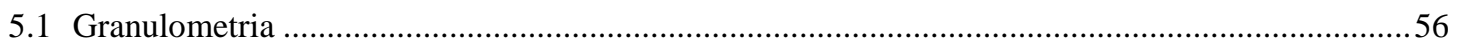

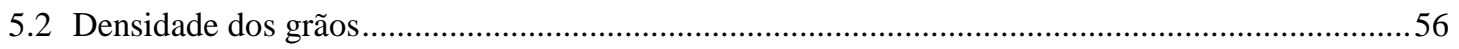

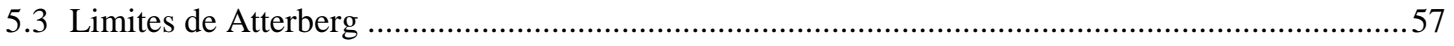

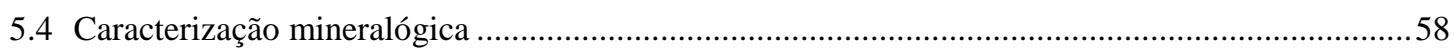




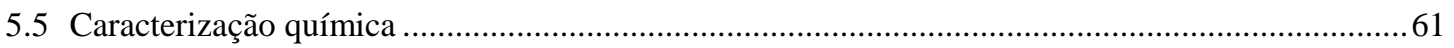

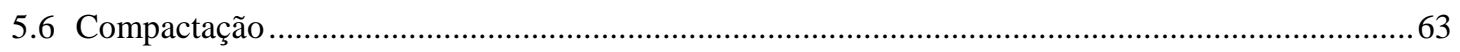

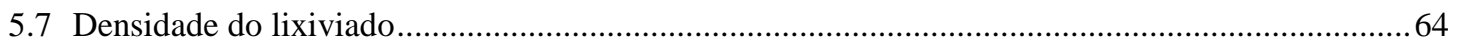

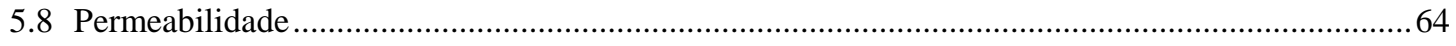

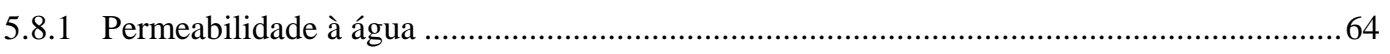

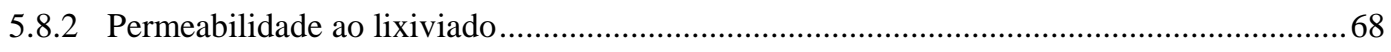

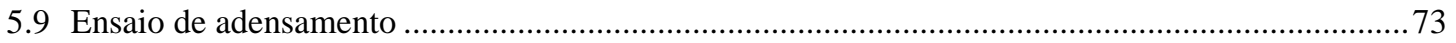

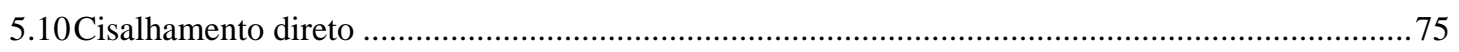

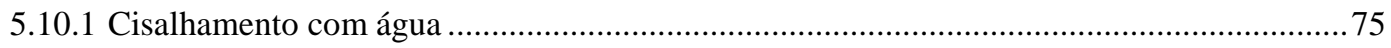

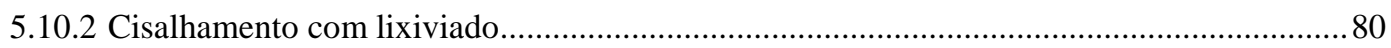

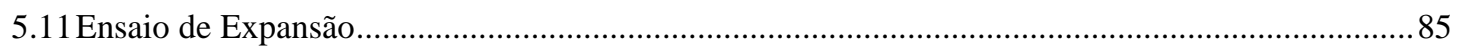

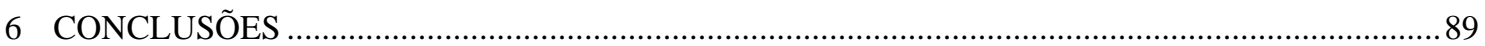

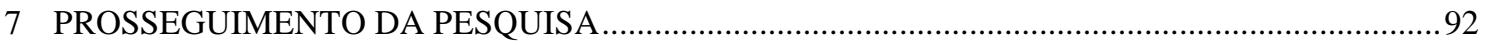

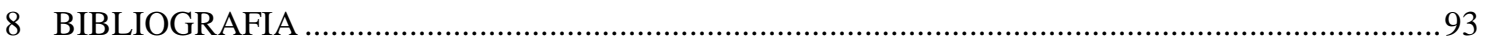




\section{LISTA DE TABELAS}

Tabela 3.1 Classificação de resíduos sólidos segundo a NBR 10004 (ABNT, 2004).

Tabela 3.2 Responsabilidade pelo gerenciamento de resíduos (BRASIL, 1988, 2010; CONAMA, 1993, 2002 e 2005; SELUR e ABLP, 2010).

Tabela 3.3 Destino final dos resíduos sólidos, por unidade de destino dos resíduos do Brasil (IBGE, 2010) ........8

Tabela 3.4 Enquadramento de um aterro de resíduos segundo o índice IQR. .................................................9

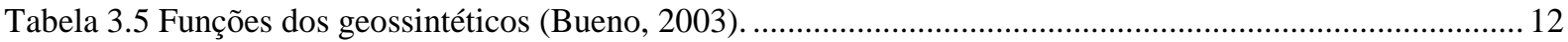

Tabela 3.6 Resultados de ensaios de expansão de um solo saprolítico de gnaisse (Stuermer, 2006)..................19

Tabela 3.7 Propriedades geotécnicas de 2 aterros experimentais (Ferrari, 2005)..........................................22

Tabela 3.8 Coeficiente de permeabilidade $(\mathrm{m} / \mathrm{s})$ em função do tempo de ensaio e do teor de bentonita (Tripathi e

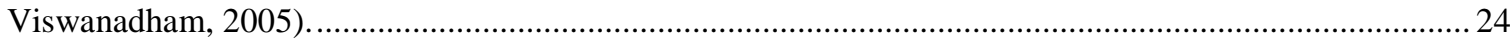

Tabela 3.9 Parâmetros de resistência ao cisalhamento (Lukiantchuki e Esquível, 2007)................................22

Tabela 3.10 Características típicas do lixiviado dos aterros brasileiros na fase ácida (Souto, 2009)................. 32

Tabela 3.11 Características típicas do lixiviado dos aterros brasileiros na fase metanogênica (Souto, 2009). ..... 33

Tabela 3.12 Composição química do lixiviado investigado por Francisca e Glatstein (2010).............................36

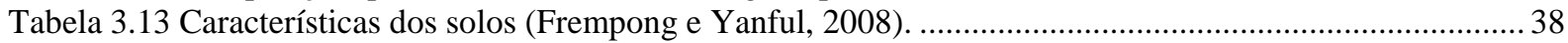

Tabela 3.14 Composição química do lixiviado (Frempong e Yanful, 2008)..................................................38

Tabela 4.1 Características geotécnicas da bentonita (Convênio EPUSP/Bentonit, 2004)...............................43

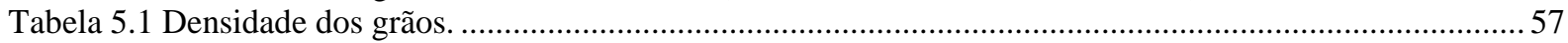

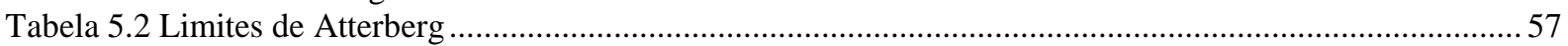

Tabela 5.3 Limites de Atterberg de solos residuais de filito do Estado de São Paulo (Cruz, 1996)...................58

Tabela 5.4 Análise química semiquantitativa do solo natural, valores expressos em \% de óxidos normalizados a $100 \%$.

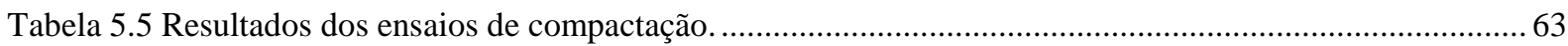

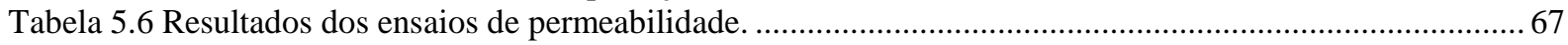

Tabela 5.7 Características de moldagem dos corpos-de-prova dos ensaios de permeabilidade ao lixiviado.........69

Tabela 5.8 Características de moldagem dos corpos-de-prova dos ensaios de adensamento. .............................73

Tabela 5.9 Parâmetros determinados pelo ensaio de adensamento. ................................................................74

Tabela 5.10 Dados de moldagem dos corpos-de-prova dos ensaios de cisalhamento direto ............................. 76

Tabela 5.11 Envoltórias de resistência - inundação com água............................................................... 79

Tabela 5.12 Dados de moldagem dos corpos-de-prova inundados com lixiviado.......................................... 81

Tabela 5.13 Envoltórias de resistência - inundação com lixiviado. .............................................................. 84

Tabela 5.14 Dados de moldagem dos corpos-de-prova dos ensaios de expansão realizados com água...............85

Tabela 5.15 Dados de moldagem dos corpos-de-prova dos ensaios de expansão realizados com lixiviado. ........86

Tabela 5.16 Resultados dos ensaios de expansão das amostras inundadas com água. ......................................8. 87

Tabela 5.17 Resultados dos ensaios de expansão das amostras inundadas com lixiviado..................................8 87

Tabela 5.18 Resultados médios dos ensaios de expansão....................................................................... 87

Tabela 5.19 Critérios de expansão de Seed et. al (1962) e Van der Merwe (1964) apud Sandroni e Consoli (2010). 


\section{LISTA DE FIGURAS}

Figura 3.1 Revestimento de fundo para resíduos de classe IIA no Estado de São Paulo.

Figura 3.2 Modelos de macroestrutura de solos saprolíticos em diferentes graus de evolução (crescente de baixo para cima) (Cruz, 1987).

Figura 3.3 Limites de consistência de solos saprolíticos (Mori, 1987)........................................................ 16

Figura 3.4 Determinação da pressão de expansão de um silte saprolítico de filito de Cuiabá-MT (Conciani, 2006).

Figura 3.5 Condutividade hidráulica em função do tempo de ensaio: (a) misturas com 5\%, 10\% e $15 \%$ de bentonita; (b) misturas com 20\% e 25\% de bentonita (Tripathi e Viswanadham 2005).........................2 24

Figura 3.6 Coeficiente de permeabilidade em função do teor de bentonita: (a) 4 semanas de ensaio; (b) 300 dias de ensaio (Tripathi e Viswanadham 2005) ................................................................................. 25

Figura 3.7 Variação da condutividade hidráulica, em cm/s, em função do teor de bentonita (Lukiantchuki e

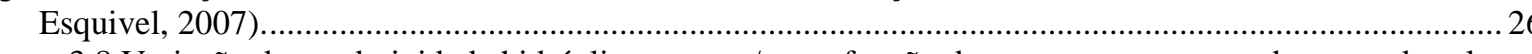

Figura 3.8 Variação da condutividade hidráulica, em cm/s, em função do tempo, para corpos de prova de solo puro e solo-bentonita, após a saturação (Lukiantchuki e Esquivel, 2007)................................................26

Figura 3.9 Curvas de compactação para misturas solo-bentonita com diversos teores de bentonita (Mizuno et al.,

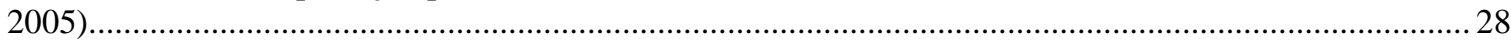

Figura 3.10 Especificação para controle de compactação em campo (Mizuno et al., 2005)..............................28

Figura 3.11 Distribuição por região dos aterros cujos dados de lixiviado foram compilados (Souto, 2009)....... 31

Figura 3.12 Permeabilidade de uma argila arenosa com água (Nascentes, 2006).........................................35

Figura 3.13 Permeabilidade de uma argila arenosa com contaminante (Nascentes, 2006).............................. 35

Figura 3.14 Coeficiente de permeabilidade $(\mathrm{cm} / \mathrm{s})$ de misturas de solo com bentonita percoladas com lixiviado

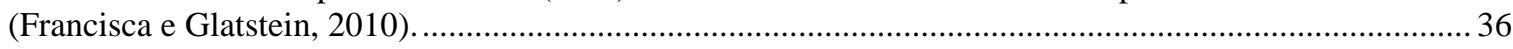

Figura 3.15 Coeficiente de permeabilidade $(\mathrm{cm} / \mathrm{s})$ de misturas de solo com bentonita percoladas com água

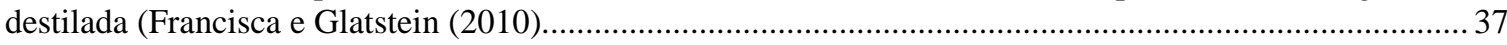

Figura 3.16 Expansão com água destilada (AD) e água de torneira (AT) (França et al., 2007) ..........................3 39

Figura 3.17 Expansão com lixiviado do Aterro Sanitário de São Carlos-SP (França et al., 2007)....................... 39

Figura 4.1 Vista superior do empreendimento (fonte: Google Earth em 09.10.2009, 14h) ...........................40

Figura 4.2 Perfil de sondagem típico da região da CTR-Caieiras (Ferrari, 2005)......................................... 41

Figura 4.3 Talude de corte no solo saprolítico de filito da região da CTR-Caieiras (Ferrari, 2005)...................42

Figura 4.4 Detalhe do solo saprolítico no momento da coleta..............................................................42

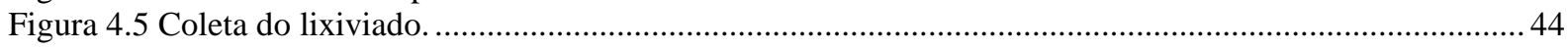

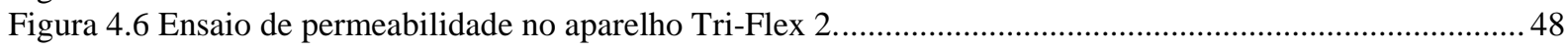

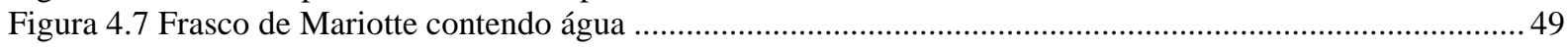

Figura 4.8 Desbastamento do corpo-de-prova para moldagem no anel de adensamento. ................................50

Figura 4.9 Foto da montagem da célula de adensamento. ...................................................................51

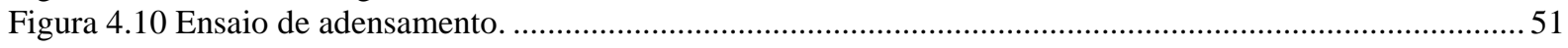

Figura 4.11 Montagem do material na caixa de cisalhamento direto. .....................................................52

Figura 4.12 Foto do andamento do ensaio de cisalhamento direto.............................................................53

Figura 4.13 Ensaio de expansão com lixiviado: (a) vista geral da montagem do ensaio; (b) detalhe da célula de expansão com utilização de papel toalha e filme plástico. .................................................................55

Figura 5.1 - Distribuição granulométrica do solo saprolítico de filito - coletas 1 e 2 ...................................56

Figura 5.2 Limites de Atterberg dos materiais estudados.......................................................................5

Figura 5.3 Mineralogia do solo natural pelo ensaio de difração de raios X. ................................................59

Figura 5.4 Cabeçote do ensaio contendo o solo natural, durante o ensaio MEV ...........................................60

Figura 5.5 Minerais encontrados durante a realização do MEV-BSE. ......................................................60

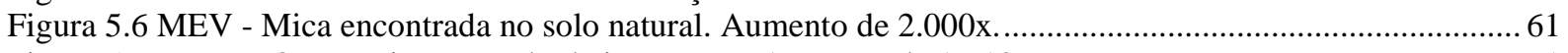

Figura 5.7 MEV - Quartzo impregnado de impurezas. Aumento de 1.710x..............................................61

Figura 5.8 MEV - Detalhe do aglomerado de óxido de ferro (impurezas). Aumento de 500x...........................61

Figura 5.9 MEV - Detalhe do material . Aumento de 5.000x.................................................................61

Figura 5.10 Curvas de compactação do solo natural e das misturas de solo com bentonita................................63

Figura 5.11 Ensaio de permeabilidade com o solo compactado no ramo seco da energia normal. ......................65

Figura 5.12 Ensaio de permeabilidade com a mistura de solo e 5\% de bentonita compactada no ramo úmido da energia normal.

Figura 5.13 Ensaio de permeabilidade com a mistura de solo e $2,5 \%$ de bentonita compactada no ramo úmido da

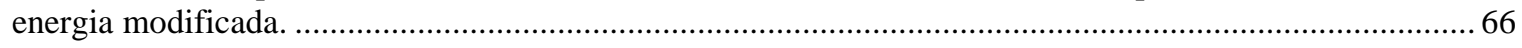


Figura 5.14 Ensaio de permeabilidade com a mistura de solo e 5\% de bentonita compactada no ramo úmido da energia modificada

Figura 5.15 Ensaio de permeabilidade com a mistura de solo e 7,5\% de bentonita compactada no ramo úmido da energia modificada.

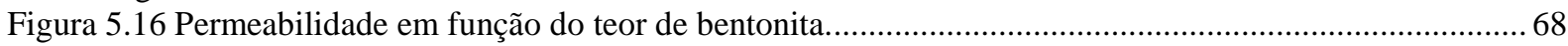

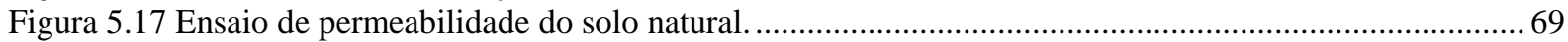

Figura 5.18 Ensaio de permeabilidade da mistura de solo com 5\% de bentonita - Ensaio 1............................. 70

Figura 5.19 Ensaio de permeabilidade da mistura de solo com 5\% de bentonita - Ensaio 2........................... 71

Figura 5.20 Ensaio de permeabilidade da mistura de solo com 5\% de bentonita - Ensaio 3........................... 72

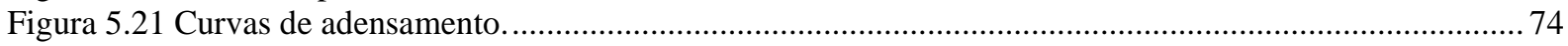

Figura 5.22 Resultados dos ensaios de cisalhamento direto com o solo natural inundado com água: (a) tensão cisalhante em função do deslocamento horizontal; (b) deslocamento vertical em função do deslocamento

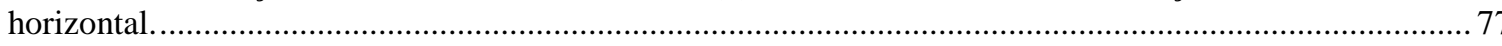

Figura 5.23 Resultados dos ensaios de cisalhamento direto com a mistura com 5\% de bentonita inundada com água: (a) tensão cisalhante em função do deslocamento horizontal; (b) deslocamento vertical em função do

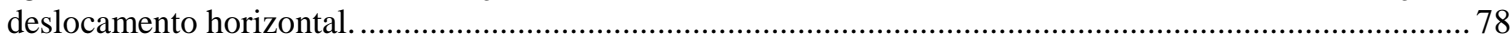

Figura 5.24 Envoltórias de resistência -inundação com água. ............................................................... 79

Figura 5.25 Resultados dos ensaios de cisalhamento direto com o solo natural inundado com lixiviado: (a) tensão cisalhante em função do deslocamento horizontal; (b) deslocamento vertical em função do deslocamento horizontal.

Figura 5.26 Resultados dos ensaios de cisalhamento direto do solo com a mistura de 5\% de bentonita inundado com lixiviado: (a) tensão cisalhante em função do deslocamento horizontal; (b) deslocamento vertical em função do deslocamento horizontal.

Figura 5.27 Envoltórias de resistência - inundação com lixiviado............................................................ 84

Figura 5.28 Tensões cisalhantes de ruptura para o solo natural e para a mistura de solo com 5\% de bentonita, inundados com água e lixiviado.

Figura 5.29 Exemplo de expansão livre dos corpos-de-prova após a retirada da carga total - ensaios com solo natural inundado com água. 
e - índice de vazios

$\mathrm{H}$ - espessura da camada de solo

$\mathrm{k}$ - coeficiente de permeabilidade

i - gradiente hidráulico

LP - limite de plasticidade

c - coesão

$\varnothing$ - ângulo de atrito

$\mathrm{B} / \mathrm{S}$ - teor de bentonita em massa seca

$\mathrm{q}_{\mathrm{c}}$ - resistência à penetração do cone

$\gamma_{d}-$ peso específico aparente seco

$\mathrm{S}$-grau de saturação

w - teor de umidade

$\mathrm{T}$ - número de volume de vazios ou poros

$\mathrm{w}_{\mathrm{mt}}$ - umidade ótima

$\Delta \mathrm{w}$ - desvio de umidade

$\mathrm{V}_{\mathrm{v}}$ - volume de vazios ou poros 


\section{RESUMO}

Soares, V.. Utilização de mistura de solo saprolítico com bentonita na construção de revestimento de fundo de aterros. 2011. 112p. Dissertação de mestrado - Escola Politécnica da Universidade de São Paulo, São Paulo, 2011.

No Estado de São Paulo, a CETESB (1993), a exemplo da maioria das legislações e regulamentações ambientais em todo o mundo, recomenda que o coeficiente de permeabilidade da camada de impermeabilização de fundo de solo compactado (CCL ou compacted clay liner) em aterros sanitários seja menor ou igual a $10^{-9} \mathrm{~m} / \mathrm{s}$. O material mais utilizado para este fim é a argila; porém, esse material já está escasso na Região Metropolitana de São Paulo (RMSP), na qual são abundantes solos saprolíticos derivados de rochas ácidas. Estudos anteriores mostraram que a permeabilidade de um solo saprolítico siltoso de filito da RMSP, da ordem de $5 \times 10^{-8} \mathrm{~m} / \mathrm{s}$ no ponto ótimo de compactação na energia normal, diminui para $6 \times 10^{-10} \mathrm{~m} / \mathrm{s}$ com adição de $5 \%$ de bentonita em peso seco e compactação na energia modificada. Este estudo visou a conhecer os efeitos da adição da bentonita no comportamento à resistência e compressibilidade desse material na presença de água e na presença de lixiviado, pois mudanças das propriedades mecânicas e hidráulicas do solo de revestimento podem comprometer sua integridade, levando à contaminação do solo e da água subterrânea. Foram realizados ensaios de cisalhamento direto, adensamento edométrico e expansão com o solo natural e com uma mistura de solo com 5\% de bentonita, compactados na energia modificada. A adição de $5 \%$ de bentonita ao solo saprolítico de filito causou pequena alteração na resistência (aumento da coesão e redução do ângulo de atrito, mas gerando envoltórias de resistência praticamente coincidentes na faixa de tensões estudadas) e ligeiro aumento da compressibilidade e da expansão. Portanto, o material torna-se adequado em termos de permeabilidade sem que sejam alteradas significativamente suas demais propriedades geotécnicas. A percolação de lixiviado pelo solo natural e pela mistura do solo com $5 \%$ de bentonita causou uma redução do coeficiente de permeabilidade para $3 \times 10^{-10} \mathrm{~m} / \mathrm{s}$, um aumento pouco significativo na compressibilidade, uma redução na expansão e uma pequena alteração nos parâmetros de resistência, a qual praticamente não modifica as envoltórias de resistência na faixa de tensões estudadas. Pode-se concluir que os dois materiais são compatíveis com o lixiviado. Tendo em vista os resultados obtidos, a mistura de solo saprolítico de filito com $5 \%$ de bentonita compactada na energia modificada é um material adequado para a construção de revestimentos de fundo de aterros sanitários.

Palavras-chave: Aterro sanitário; Solo tropical; Bentonita; Chorume; Impermeabilização. 


\begin{abstract}
Soares, V.. Use of saprolite soil mixture with bentonite in the construction of landfill liner. 2011. 112p. Master thesis - Polytechnic University of São Paulo, São Paulo, 2011.

The Environmental Protection Agency from São Paulo State (Brazil), as most environmental regulations in the world, recommends a permeability coefficient equal or lower than $10^{-9} \mathrm{~m} / \mathrm{s}$ for the bottom mineral liner in sanitary landfills. Clays are nowadays scarce in the Metropolitan Region of São Paulo (MRSP), whereas saprolitic sandy silts derived from acidic rocks are abundant in the area. Previous studies showed that the permeability of a saprolitic silt derived from phyllite from MRSP, which is $5 \times 10^{-8} \mathrm{~m} / \mathrm{s}$ at the optimum water content under normal Proctor effort, decreases to $6 \times 10^{-10} \mathrm{~m} / \mathrm{s}$ with the addition of $5 \%$ bentonite (dry weight) and compaction under modified Proctor effort. This research aimed at verifying the effects of bentonite addition on the shear strength and compressibility of this material in the presence of water and leachate, since alterations in the mechanical an hydraulic properties may damage the bottom liner and cause the pollution of the subsoil and subterranean waters. Direct shear, edometric compression and expansion tests were carried out with the natural soil and a mixture of soil and 5\% bentonite, compacted under modified Proctor effort. The addition of $5 \%$ bentonite to the soil caused a slight alteration in the shear strength (increase of cohesion and decrease of friction angle, however resulting in practically coincident strength envelopes for the range of applied stresses), and slight increase of compressibility and expansion. Therefore, the material is adequate in terms of permeability without significant alteration of other geo-mechanical properties. Leachate seepage through the natural soil and through the mixture resulted in a reduction of permeability to $3 \times 10^{-10} \mathrm{~m} / \mathrm{s}$, and a slight increase of compressibility, a reduction of expansion and a slight alteration in shear strength parameters, which however practically did not modify the strength envelopes for the range of applied stresses. It can be concluded the both materials are compatible to the leachate. Based on the results of this research, a mixture of the saprolitic soil of phyllite with $5 \%$ bentonite compacted under modified Proctor energy is an adequate material for the construction of bottom liners in sanitary landfills.
\end{abstract}

Keywords: Sanitary landfill; Tropical soils; Bentonite; Leachate; Waterproofing; 


\section{OBJETIVO}

Este estudo visa investigar o comportamento geomecânico de um silte saprolítico de filito da Região Metropolitana de São Paulo com adição de bentonita como material de impermeabilização de fundo de aterro sanitário. 


\section{JUSTIFICATIVA}

Não há ainda solução que evite um município de ter uma área controlada para a disposição de seus resíduos. Mesmo considerando a reciclagem, a compostagem, e até mesmo a incineração da maioria de seus resíduos, ainda assim há a necessidade de uma área para disposição dos mesmos.

Os problemas com a disposição de lixo urbano há tempos são conhecidos: proliferação de animais transmissores de doenças, aumento da incidência de doenças, enchentes, contaminação do solo, contaminação da atmosfera, contaminação das águas superficiais e subterrâneas. Também são observadas alterações das condições dos materiais que constituem o local de disposição, como abertura de fendas, mudança na permeabilidade e desenvolvimento de recalques. Portanto, os locais de disposição de resíduos sólidos urbanos (RSU) devem ser projetados e construídos de maneira a evitar esses problemas e garantir a segurança ambiental.

Atualmente a Companhia Ambiental do Estado de São Paulo (CETESB, 1999), a exemplo da maioria das legislações e regulamentações ambientais em todo o mundo, recomenda que o coeficiente de permeabilidade da camada de impermeabilização de fundo de solo compactado em aterros sanitários seja menor ou igual a $10^{-9} \mathrm{~m} / \mathrm{s}$. O material mais utilizado é a argila, de onde vem a denominação "CCL" ("compacted clay liner", ou seja, revestimento de argila compactada) para essas barreiras. Contudo, argilas já estão escassas em certas áreas da Região Metropolitana de São Paulo (RMSP). Assim surge a necessidade de procurar materiais alternativos eficientes, cuja utilização seja ecologicamente sustentável e, ao mesmo tempo, viável do ponto de vista econômico.

Os materiais naturais mais abundantes atualmente na RMSP são os solos siltosos saprolíticos derivados de granitos, gnaisses e filitos. Esses solos, porém, quando compactados no ponto ótimo ou no ramo úmido, apresentam coeficiente de permeabilidade da ordem de $10^{-8} \mathrm{~m} / \mathrm{s}$, o que inviabiliza sua utilização na construção de CCLs segundo as recomendações da CETESB. 
Estudo anterior (Ferrari, 2005) mostrou que a permeabilidade de um solo saprolítico siltoso de filito de Caieiras com adição de bentonita compactado na energia modificada diminuiu para cerca de $10^{-9} \mathrm{~m} / \mathrm{s}$.

A adição de bentonita pode, portanto, viabilizar a utilização desse material na construção de CCLs de aterros sanitários do ponto de vista da permeabilidade. Por outro lado, pode causar mudanças nas propriedades hidráulicas, químicas e mineralógicas do solo de revestimento que comprometam a integridade do CCL, levando à contaminação do subsolo e da água subterrânea (Frempong e Yanful, 2008).

Nesta pesquisa foram investigados os efeitos da adição da bentonita na resistência, compressibilidade e expansão do solo saprolítico siltoso de filito de Caieiras para comprovar a viabilidade técnica da utilização desse material na construção de CCLs, considerando tanto o comportamento hidráulico, já estudado por Ferrari (2005), como o comportamento mecânico da mistura. 


\section{REVISÃO BIBLIOGRÁFICA}

\subsection{ATERROS SANITÁRIOS}

A Norma Brasileira NBR 10004 (ABNT, 2004) apresenta uma classificação de resíduos sólidos quanto ao potencial de risco ao meio ambiente e saúde pública (Tabela 3.1). Para cada classe de resíduo é previsto um tipo de disposição final. Os resíduos sólidos urbanos (RSU) são considerados resíduos Classe IIA pela ABNT.

Tabela 3.1 Classificação de resíduos sólidos segundo a NBR 10004 (ABNT, 2004).

\begin{tabular}{cr}
\hline Tipo & Características \\
\hline CLASSE I & Apresentam risco à saúde pública ou ao meio ambiente, caracterizando- \\
(PERIGOSOS) & se por ter uma ou mais das seguintes propriedades: inflamabilidade, \\
CLASSE IIA & corrosividade, reatividade, toxicidade e patogenicidade. \\
(NÃO-INERTES) & Podem ter propriedades como combustibilidade, biodegradabilidade, \\
CLASSE IIB & porém não se enquadram como resíduos I ou IIB. \\
& Não têm nenhum dos seus constituintes (inertes) solubilizados em \\
concentrações superiores aos padrões de potabilidade da água
\end{tabular}

A Constituição Federal inicialmente estabeleceu que o gerenciamento dos serviços públicos de limpeza urbana, de interesse local, é de competência municipal (BRASIL, 1988), compreendendo os resíduos domiciliares, comerciais (até determinado volume, dependendo do município) e públicos. Ao longo dos anos, foram sendo estabelecidas resoluções do CONAMA - Conselho Nacional do Meio Ambiente a respeito de determinados resíduos especiais (serviços de saúde, portos e aeroportos, terminais rodoviários e ferroviários, construção civil etc.), válidas em âmbito federal, enquanto os Estados foram adotando suas próprias legislações de resíduos sólidos.

A Lei 12.305, que instituiu a Política Nacional de Resíduos Sólidos (PNRS), em seu art. 10 “Incumbe ao Distrito Federal e aos Municípios a gestão integrada dos resíduos sólidos gerados nos respectivos territórios, sem prejuízo das competências de controle e fiscalização dos órgãos federais e estaduais do Sisnama ${ }^{1}$, do $S_{N V S^{2}}$ e do Suasa ${ }^{3}$, bem como da

\footnotetext{
${ }^{1}$ Sisnama - Sistema Nacional do Meio Ambiente. (http://www.mma.gov.br/port/conama/estr1.cfm)

${ }^{2}$ SNVS - Sistema Nacional de Vigilância Sanitária. (http://www.anvisa.gov.br/Institucional/snvs/index.htm)

${ }^{3}$ Suasa - Sistema Único de Atenção à Sanidade Agropecuária.(http://portal.mda.gov.br/portal/saf/programas/suasa)
} 
responsabilidade do gerador pelo gerenciamento de resíduos, consoante o estabelecido nesta Lei” (BRASIL, 2010). A Tabela 3.2 mostra a distribuição da responsabilidade pelo gerenciamento de resíduos.

Tabela 3.2 Responsabilidade pelo gerenciamento de resíduos (BRASIL, 1988, 2010;

CONAMA, 1993, 2002 e 2005; SELUR e ABLP, 2010).

\begin{tabular}{cc}
\hline Tipos & Responsável \\
\hline Domiciliar & Município \\
Comercial & $\begin{array}{c}\text { Município (para pequenas quantidades) } \\
\text { Gerador (para grandes quantidades) }\end{array}$ \\
Público & Município \\
Serviços de saúde & Gerador \\
Industrial & Gerador \\
Portos, aeroportos, terminais rodoviários e & Gerador \\
ferroviários & Gerador \\
Entulho &
\end{tabular}

A gestão integrada de resíduos é definida como um conjunto de ações voltadas à busca de soluções para os resíduos sólidos de forma a considerar as dimensões política, econômica, ambiental, cultural e social, com controle social e sob a premissa do desenvolvimento sustentável (BRASIL, 2010); compreende um ciclo em que se busca seqüencialmente a não geração, redução, reutilização, reciclagem, coleta, transporte, redução volumétrica, atenuação de características adversas dos resíduos a serem dispostos e a disposição final em aterros.

Os resíduos gerados nos municípios são classificados pelo PNRS (BRASIL, 2010) em diversas categorias pela origem, sendo denominados resíduos sólidos urbanos (RSU) os resíduos domiciliares (originários de atividades domésticas em residências urbanas) e resíduos de limpeza urbana (originários da varrição, limpeza de logradouros e vias públicas e outros serviços de limpeza urbana). Tradicionalmente são denominados RSU aqueles gerados nas residências, no comércio e em outras atividades desenvolvidas nas cidades (LIMPURB, 2006), ou seja, incluem-se os resíduos gerados no comércio em pequenas quantidades, embora segundo o PNRS os resíduos de estabelecimentos comerciais e prestadores de serviços formem uma categoria à parte. 
Para os RSU, a disposição final ocorre de três maneiras: lixão ou vazadouro, aterro controlado ou aterro sanitário. Lixão ou vazadouro é a simples deposição sobre terreno natural, sem nenhum cuidado ou preparação anterior. No aterro controlado os resíduos são cobertos periodicamente por camadas de terra e/ou entulho, e podem também ser periodicamente compactados. O aterro sanitário pode ser definido como uma forma de disposição de resíduos sólidos urbanos no solo que, fundamentada em critérios de engenharia e normas operacionais específicas, permite o confinamento seguro em termos de controle de poluição ambiental e proteção à saúde pública, minimizando impactos ambientais (IPT/CEMPRE, 2000). Segundo Boscov e Abreu (2000), o conceito de aterro de resíduos compreende um sistema devidamente preparado para a disposição dos resíduos sólidos, englobando, sempre que necessário, determinados componentes e práticas operacionais, tais como: divisão em células, compactação dos resíduos, cobertura, sistema de impermeabilização, sistemas de drenagem e tratamento para líquidos e gases, monitoramento geotécnico e ambiental, entre outros.

A Pesquisa Nacional de Saneamento Básico (PNSB), publicada pelo IBGE (2010), revela que apesar de existir uma melhora da situação da destinação final dos resíduos sólidos coletados no país nos últimos anos, tal situação permanece aquém do ideal, como se observa na Tabela 3.3 .

Tabela 3.3 Destino final dos resíduos sólidos, por unidade de destino dos resíduos do Brasil (IBGE, 2010)

\begin{tabular}{rccc}
\hline \multirow{2}{*}{ Ano } & \multicolumn{3}{c}{ Destino final dos resíduos sólidos, por unidade de destino dos resíduos } \\
& \multicolumn{4}{c}{$(\boldsymbol{\%})$} \\
\cline { 2 - 4 } 1989 & Aterro sanitário & Aterro Controlado & Vazadouro \\
\cline { 2 - 4 } 2000 & 1,1 & 9,6 & 88,2 \\
2008 & 17,3 & 22,3 & 72,3 \\
& 27,7 & 22,5 & 50,8 \\
\hline
\end{tabular}

O Inventário Estadual de Resíduos Sólidos Domiciliares do Estado de São Paulo (CETESB, 2008) avalia os locais de disposição do Estado de São Paulo por meio dos índices IQR (índice de qualidade de aterro de resíduos), IQC (índice de qualidade de usinas de compostagem) e IQV (índice de qualidade de aterros de resíduos em valas). Esta avaliação é realizada a partir de um questionário padronizado relativo à localização, estrutura e operação de cada instalação. Em função do IQR, o aterro de resíduos é enquadrado conforme a Tabela 3.4. 
Tabela 3.4 Enquadramento de um aterro de resíduos segundo o índice IQR.

\begin{tabular}{cc}
\hline IQR & Enquadramento \\
\hline 0,0 a 6,0 & Condições inadequadas (I) \\
6,1 a 8,0 & Condições controladas (C) \\
8,1 a 10,0 & Condições adequadas (A) \\
\hline
\end{tabular}

O IQR médio dos sistemas de disposição final de resíduos sólidos domiciliares em operação nos Municípios do Estado de São Paulo foi 8,5 em 2009; em 1997 este índice era 4,0, confirmando a tendência de melhoria da disposição de resíduos observada no país pela PNSB (Estado de São Paulo, 2009).

Segundo o Inventário Estadual (CETESB, 2010), a quantidade de resíduos sólidos dispostos adequadamente passou de 10,9\% em 1997 para 83,9\% em 2009. Verificou-se na ocasião que houve um aumento de volume de resíduos nas residências, pequenos estabelecimentos comerciais e empreendimentos de pequeno porte, porém com melhora em sua disposição.

Em 2009, conforme se verifica no Inventário Estadual de Resíduos Sólidos Domiciliares do Estado de São Paulo (CETESB, 2010), dos 39 municípios que compõem a Região Metropolitana de São Paulo, 4 dispõem seus resíduos em aterros públicos e 35 em aterros particulares, entre eles a Central de Tratamento de Resíduos Caieiras (CTR-Caieiras), no município de Caieiras, ocupando uma área de 3,5 milhões de $\mathrm{m}^{2}$ e projetado para receber 60 milhões de $\mathrm{m}^{3}$ de resíduos (Essencis, 2009), de onde foi retirado o solo investigado nesta pesquisa.

\subsection{IMPERMEABILIZAÇÃO DE FUNDO DE ATERROS SANITÁRIOS}

Atualmente o paradigma do aterro sanitário é o confinamento dos resíduos para evitar a liberação de substâncias nocivas ao meio ambiente e à saúde humana. Um dos principais objetivos é evitar ou minimizar a contaminação do subsolo e principalmente do lençol freático pelo líquido produzido na massa de resíduos (chorume, lixiviado ou percolado), já que a escassez de água potável como recurso natural vem se tornando, a cada dia, um assunto mais preocupante. Por exemplo, Mondelli (2004), por meio de ensaios geofísicos in situ e ensaios laboratoriais com amostras de água e solo coletadas no local, concluiu que a pluma de contaminação gerada por vazamento de lixiviado pela base do aterro de Bauru (SP) já 
ultrapassava os limites do aterro para jusante. Também deve ser evitada a saída de líquidos, gases ou partículas pela superfície do aterro, que possam contaminar as águas superficiais ou a atmosfera. Por exemplo, Schueler \& Mahler (2007) observaram contaminação do solo no entorno do aterro de Paracambi (RJ) causada por escoamento do lixiviado sobre a superfície descoberta do aterro. O local de disposição de resíduos deve contar, assim, com impermeabilização de fundo e de cobertura.

Um local com topografia, clima e hidrogeologia favoráveis pode compor barreiras naturais para a contenção dos resíduos. Portanto, são características desejáveis de localização de aterros sanitários: um subsolo de baixa permeabilidade, para evitar a percolação de chorume, e nível freático profundo, pois a zona de aeração do subsolo degrada a carga poluente bacteriológica se houver escape de lixiviado, além de que a permeabilidade não saturada é mais baixa do que a saturada. Brollo (2001) considera que o terreno deve não apenas constituir uma fundação estável para o aterro, como também, ter uma função de impermeabilização; no caso de ruptura das barreiras técnicas, cumpriria uma função retentora para o lixiviado e suas substâncias nocivas.

A maioria das normas internacionais para sistemas de impermeabilização inferior de aterros de RSU recomenda que a camada de solo compactado apresente um coeficiente de permeabilidade da ordem de $10^{-9} \mathrm{~m} / \mathrm{s}$ e que se empregue geomembrana (GM) de polietileno de alta densidade (PEAD) sobre a camada de solo compactado. O valor do coeficiente de permeabilidade $10^{-9} \mathrm{~m} / \mathrm{s}$ vem do estudo de Potter e Yong (1993), que baseado na lei de Darcy, considerava um tempo de 30 anos, após o qual o lixiviado deixaria de ser poluente, para que atravessasse a camada de solo compactado de 1 metro de espessura, considerando gradiente hidráulico unitário.

Em São Paulo, a CETESB - Companhia Ambiental do Estado de São Paulo (1993) recomenda a seguinte configuração (Figura 3.1) para um sistema de impermeabilização de fundo para resíduos de classe IIA: uma camada de solo argiloso compactado com espessura de 0,60 m e coeficiente de permeabilidade inferior a $10^{-9} \mathrm{~m} / \mathrm{s}$ coberta por uma geomembrana de PEAD com espessura de $2,0 \mathrm{~mm}$ e coeficiente de permeabilidade da ordem de $10^{-14} \mathrm{~m} / \mathrm{s}$. 


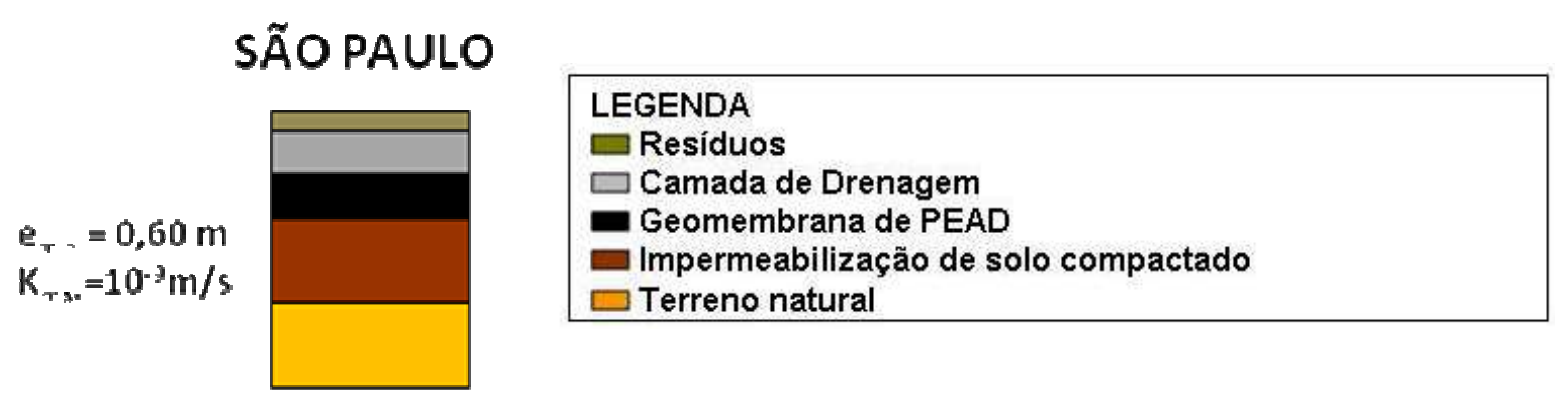

Figura 3.1 Revestimento de fundo para resíduos de classe IIA no Estado de São Paulo.

Atualmente está crescendo a utilização de membranas constituídas por uma camada de bentonita entre dois geotêxteis, ou uma camada de bentonita sob uma geomembrana, que são os chamados geocompostos bentoníticos ("geosynthetic clay liner"), também conhecidos por GCL ou GCB (geossintético argiloso para barreira de fluxo ou geossintético bentonítico). Embora o produto ainda não esteja normalizado em muitos países, sua utilização é crescente devido, entre outros fatores, à facilidade de colocação, principalmente nos taludes, onde é difícil a compactação do solo.

O sistema composto CCL-GM parte do princípio que a probabilidade de um defeito ou dano na geomembrana coincidir com uma fissura da camada argilosa é muito baixa. Assim, eventuais vazamentos na manta, rápidos e pontuais, são minimizados pelo solo compactado abaixo, onde a percolação se dá de forma lenta. Para que este sistema seja eficiente é necessário que haja contato total entre as duas camadas, caso contrário o fluido poderia passar facilmente pela primeira camada e fluir entre as duas até encontrar a falha da camada inferior.

$\mathrm{Na}$ engenharia geotécnica, os geossintéticos são utilizados em associação com outros materiais de construção, e praticamente todos os geossintéticos são utilizados em obras de engenharia ambiental. A Tabela 3.5 mostra as funções dos geossintéticos. 
Tabela 3.5 Funções dos geossintéticos (Bueno, 2003).

\begin{tabular}{ccccccccc}
\hline \multirow{2}{*}{ Funçães } & \multicolumn{7}{c}{ Geossintéticos } \\
& GT & GG & GM & GN & GP & GA & GCB & GL \\
\hline Filtração & $\mathrm{X}$ & & & & & & & \\
Drenagem & $\mathrm{X}$ & & & $\mathrm{X}$ & $\mathrm{X}$ & $\mathrm{X}$ & & \\
Separação & $\mathrm{X}$ & & $\mathrm{X}$ & & & & $\mathrm{X}$ & \\
Reforço & $\mathrm{X}$ & $\mathrm{X}$ & & & & & $\mathrm{X}$ \\
Barreira de fluidos & $\mathrm{X}$ & & $\mathrm{X}$ & & & & $\mathrm{X}$ & \\
Encapsulamento & $\mathrm{X}$ & $\mathrm{X}$ & $\mathrm{X}$ & & & & & \\
Proteção & $\mathrm{X}$ & & & & & & & \\
Barreira de solo & $\mathrm{X}$ & & & & & & & \\
Estabilização superficial & & $\mathrm{X}$ & & & & & \\
Reforço de vegetação & & $\mathrm{X}$ & & $\mathrm{X}$ & $\mathrm{X}$ & & \\
Isolação & $\mathrm{X}$ & & & & & & \\
\hline
\end{tabular}

GT: geotêxtil; GG: geogrelha; GM: geomembrana; GN: georede; GP: geotubo; GA: geomanta;

GCB: geocomposto bentonítico; GL: geocélula

Conforme a Tabela 3.5 as funções do geocomposto bentonítico (GCB) são:

- Separação: evita que materiais se misturem, por meio de sua estanqueidade (geomembranas) ou abertura de poros (geotêxteis).

- Barreira de fluidos: evita a passagem de fluidos devido à sua estanqueidade.

As funções da geomembrana, por sua vez, são separação, barreira de fluidos e encapsulamento. As geomembranas são praticamente impermeáveis quando bem instaladas, ou seja, com limitação de rasgos, dobras e número e tamanho de furos, porém, podem sofrer degradação em meios agressivos.

Laespiga (2008) realizou ensaios de condutividade hidráulica de CCL e GCL com uma solução de $\mathrm{CuCl}_{2} \cdot 2 \mathrm{H}_{2} \mathrm{O}$ buscando avaliar seus desempenhos. Após alguns dias de percolação observou-se que o GCL teve o coeficiente de permeabilidade aumentado em 200 vezes, enquanto não ocorreram mudanças no coeficiente de permeabilidade do CCL, gerando dúvidas quanto ao desempenho do GCL como barreira de fundo em contato com soluções que possam alterar sua estrutura interna e demonstrando que em alguns casos o CCL pode ter o desempenho igual ou melhor que o GCL. Segundo Di Emidio et al. (2011), com base em diversos autores, a condutividade hidráulica de GCLs aumenta à medida que aumentam a 
concentração e valência do eletrólito percolando pelo solo, devido à compressão da camada dupla dos argilominerais. Embora isto também ocorra na fração argilosa do CCL, o efeito é muito maior no GCL, pois a bentonita é composta quase que totalmente pela fração argila, e esta, por sua vez, por argilo-minerais do grupo das montmorillonitas.

Ressalta-se que um bom desempenho de um sistema impermeabilizante de fundo depende tanto da qualidade da geomembrana, como dos cuidados na sua instalação e da construção adequada da camada de solo compactado subjacente. Vidal (2007) salienta que o bom desempenho da barreira impermeabilizante depende de um projeto executivo bem detalhado, instalação executada com controle de qualidade e fiscalização adequada da instalação.

A maioria dos países, inclusive o Brasil, impõe características para a barreira mineral em função da classificação do resíduo. Por exemplo, segundo as diretrizes da Comunidade Européia para aterros de resíduos, o padrão para CCL é 5m de espessura com permeabilidade de $10^{-9} \mathrm{~m} / \mathrm{s}$ para resíduos perigosos; para resíduos não perigosos, o padrão para CCL é $1 \mathrm{~m}$ de espessura com permeabilidade de $10^{-9} \mathrm{~m} / \mathrm{s}$ (EC, 2003). No Estado de São Paulo, o padrão para resíduos classe I é uma camada de solo argiloso compactado de $1 \mathrm{~m}$ de espessura com coeficiente de permeabilidade inferior a $10^{-9} \mathrm{~m} / \mathrm{s}$, duas geomembranas de PEAD com espessura de $2 \mathrm{~mm}$, e uma camada drenante entre as geomembranas para captar o lixiviado, caso haja infiltração pela primeira geomembrana. Para resíduos classe IIa, utiliza-se uma camada de solo argiloso compactado de 0,6 m de espessura com coeficiente de permeabilidade inferior a $10^{-9} \mathrm{~m} / \mathrm{s}$ e uma geomembrana de PEAD com espessura de $2 \mathrm{~mm}$.

Estudos vêm sendo desenvolvidos para determinar a equivalência de sistemas alternativos a essas diretrizes. Conti e Nettuno (2005), por exemplo, consideram que o nível de desempenho do sistema de impermeabilização de barreiras minerais pode ser avaliado apenas considerando o tempo necessário para o lixiviado atravessar a barreira. O tempo de travessia do sistema de impermeabilização, segundo a lei de Darcy, é função da velocidade de fluxo, que depende do gradiente hidráulico. Quando as diretrizes impõem carga hidráulica zero no sistema impermeabilizante durante o período de gerenciamento, ou seja, gradiente hidráulico unitário, a equivalência é dada pela relação $\mathrm{H} / \mathrm{k}$, onde $\mathrm{H}$ é espessura e k a permeabilidade.

A determinação da resistência e da deformabilidade da barreira mineral é importante para a análise de estabilidade dos taludes da base do aterro, principalmente quando se considera a 
interface com outros materiais, como as geomembranas e os geocompostos bentoníticos. Rupturas têm sido observadas nessas interfaces (ISSMGE, 2005).

O estudo de viabilidade de materiais alternativos para CCLs geralmente compreende as propriedades de permeabilidade, resistência e deformabilidade do solo, sendo esperado que, futuramente, estudos de transporte de poluentes façam também parte dessa avaliação. Segundo Boscov (2008), o conhecimento dos processos potencialmente causadores de impacto ambiental, como o transporte de poluentes e a compatibilidade entre lixiviado e solo, poderão permitir maior flexibilidade na elaboração dos projetos.

\subsection{SOLOS SAPROLÍTICOS}

Os solos tropicais diferem dos solos temperados devido a seu processo de intemperismo. Nos trópicos, o intemperismo químico das rochas predomina sobre o intemperismo físico. A alta pluviosidade, altas temperaturas e águas ácidas devidas à decomposição de compostos orgânicos que infiltram no solo favorecem as reações químicas que alteram os minerais, o que caracteriza o intemperismo químico.

Os principais grupos de solos tropicais são os solos lateríticos e os solos saprolíticos. Segundo

o Comitê de Solos Tropicais da Associação Internacional de Mecânica dos Solos e Engenharia de Fundações (atual Associação Internacional de Mecânica dos Solos e Engenharia Geotécnica), o solo pode ser considerado saprolítico se for solo no sentido geotécnico (não precisa de explosivos para ser escavado), se exibir claramente feições estruturais herdadas da rocha matriz que permitam identificá-la e se for autenticamente residual (ISSMFE, 1985).

Os solos saprolíticos sofreram intenso processo de intemperismo, pelo qual a rocha teve uma intensa e rápida desagregação. As características mecânicas da rocha original se modificam, mas a aparência visual, falhas, folheações, intrusões, xistosidades, descontinuidades e veios de outros materiais, são preservados. Os solos saprolíticos mantêm a estrutura da rocha-mãe, permitindo inferir sua origem e podendo ser confundidos com a própria rocha.

Vargas (1977) define saprolito como sendo o solo que mantém a estrutura original da rochamatriz, inclusive veios intrusivos, fissuras, xistosidades e camadas, mas que perdeu totalmente 
sua consistência, podendo se confundir com uma rocha alterada, esboroando-se completamente pela pressão dos dedos. Pela ISSMFE (1985), no entanto, este seria o solo saprolítico, sendo saprolito a rocha em elevado grau de degradação.

O início do processo de intemperização da rocha ocorre devido à micro-fissuração seguida de dissolução e redistribuição dos materiais. Isto caracteriza uma perda de resistência ou rigidez, mudança de cor, textura, consistência, forma e volume. As alterações ao longo do perfil saprolítico não se dão de forma homogênea, uma vez que se propagam a partir das descontinuidades e fraturas, por onde a água infiltra (Figura 3.2).

Os solos saprolíticos se localizam, geralmente, entre uma camada de solo laterítico e a rocha matriz, apresentando grandes espessuras, coloração variegada, textura variável, veios, diáclases e fraturas conforme a rocha de origem.

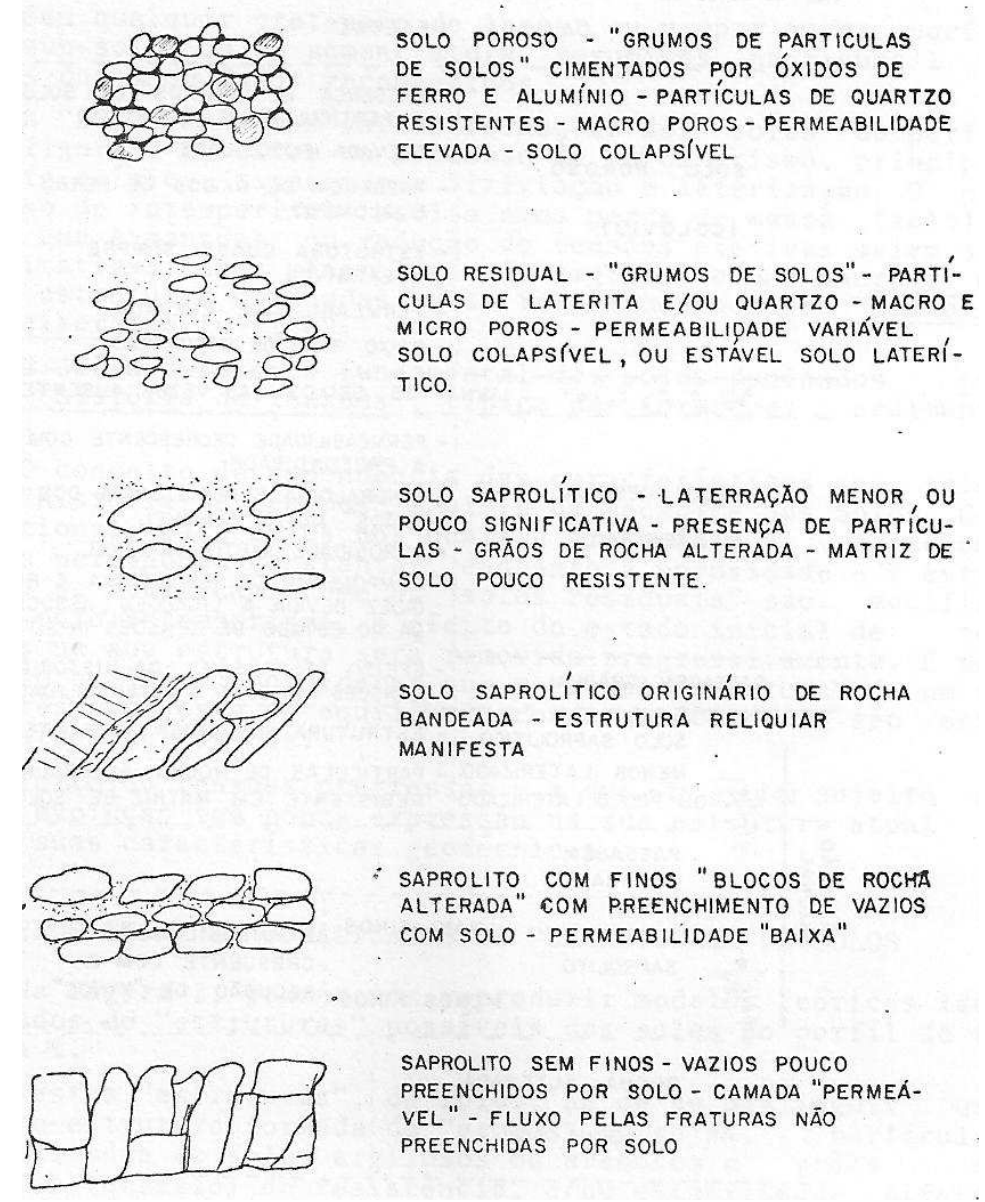

Figura 3.2 Modelos de macroestrutura de solos saprolíticos em diferentes graus de evolução (crescente de baixo para cima) (Cruz, 1987). 
Segundo Carvalho et al. (2006), uma característica dos solos saprolíticos são os valores de pH próximos do neutro e elevada troca catiônica (CTC), apresentando ainda, granulometria bastante variada devido ao seu caráter residual (Nogami e Villibor, 1995).

Segundo Mori (1987), a caracterização desses solos por ensaios de laboratório, em amostras eventualmente destorroadas e/ou ressecadas, é considerada uma tarefa difícil, visto que altera a estrutura herdada da rocha matriz. Ainda, os ensaios de Limites de Atterberg, de granulometria e de compactação destroem a estrutura original do solo, introduzem uma ativação irreal da fração argilosa e liberam água livre que havia sido retida nos torrões de solo. No estado natural, os solos saprolíticos não apresentam elevados valores de plasticidade, porém quando amolgados, após sua cimentação ser quebrada, ocorre um aumento do limite de plasticidade (LP). Ainda assim, os ensaios de caracterização são realizados e utilizados de forma padrão. De modo geral, os solos saprolíticos se posicionam perto da linha A na Carta de Casagrande (Figura 3.3)

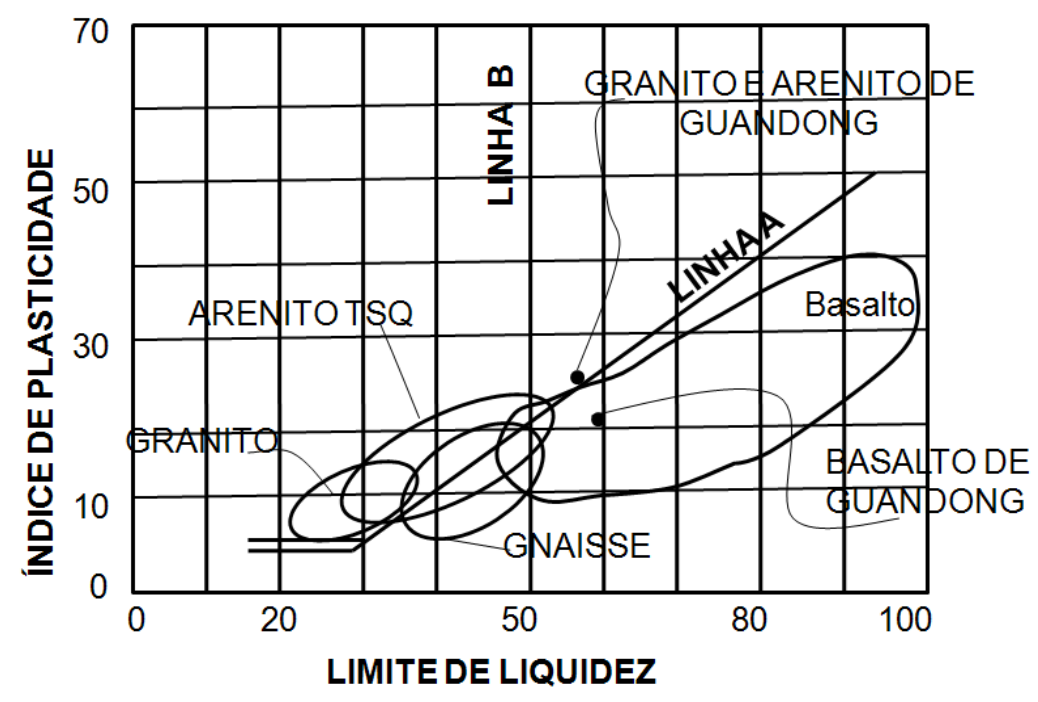

Figura 3.3 Limites de consistência de solos saprolíticos (Mori, 1987).

Os resultados dos ensaios de granulometria nos solos saprolíticos podem se alterar em função da preparação da amostra: esforços mais intensos podem causar um maior número de quebras dos grãos, dos torrões e de pedaços intactos de rocha alterada; independente da origem, os solos saprolíticos geralmente apresentam curva granulométrica bem distribuída, contendo desde pedregulhos até argilas (Mori, 1987). Esta variação da granulometria é devida ao seu caráter residual, sendo que a fração predominante é função do grau de intemperização do solo (Nogami e Villibor, 1995). 
Mori (1987) aponta para a diferença existente nas características e comportamento do solo saprolítico no estado natural e quando compactado. No estado natural influem nas suas características a orientação da rocha matriz e a porosidade advinda da lixiviação e decomposição causadas por agentes do intemperismo. No estado compactado, porém, ocorre o rearranjo da massa, com a parte mais decomposta envolvendo os blocos mais resistentes e menos alterados. A densidade dos solos compactados é mais elevada devido a um melhor entrosamento da massa, o que resulta também num material mais homogêneo.

Alguns parâmetros de resistência ao cisalhamento de solos saprolíticos brasileiros compilados em Stuermer (2006):

- Índice de vazios: $0,4 \leq \mathrm{e} \leq 1,66$;

- Coesão: $0 \leq \mathrm{c} \leq 86 \mathrm{kN} / \mathrm{m}^{2}$; e

- Ângulo de atrito: $19^{\circ} \leq \varnothing \leq 43^{\circ}$.

Cruz (1996) apresenta uma variação de $0 \leq \mathrm{c} \leq 50 \mathrm{kN} / \mathrm{m}^{2}$ e $13^{\circ} \leq \emptyset \leq 29^{\circ}$ para um solo saprolítico de filito do Estado do Espírito Santo.

Moura e Garcia (1985) determinaram o ângulo de atrito de dois solos siltosos saprolíticos de filito, um solo sericítico (micáceo) de Minas Gerais e um solo caulínico de São Paulo, por meio de ensaios de compressão triaxial adensados não drenados com amostras compactadas no ponto ótimo da energia normal e saturadas por contrapressão, obtendo coesão nula e ângulo de atrito de $30^{\circ}$ para os dois solos. Em ensaios de cisalhamento direto realizados em diversas condições de saturação, os solos apresentaram certa coesão (até $40 \mathrm{kPa}$ para o solo sericítico e até $50 \mathrm{kPa}$ para o solo caulínico), que foi totalmente perdida pela saturação.

O ângulo de atrito de solos saprolíticos compactados determinado por meio de ensaios de compressão triaxial drenados, com a hipótese de coesão nula, varia de 28 a $29^{\circ}$ para saprolitos de basalto, de 29 a $32^{\circ}$ para saprolitos de gnaisse e de 38 a $40,5^{\circ}$ para saprolitos de granito. A resistência ao cisalhamento é influenciada pelos torrões intatos, que ainda preservam a estrutura e a dureza originais, de modo que o solo saprolítico compactado no campo deve apresentar resistência maior do que o compactado no laboratório (Mori, 1987). Cruz (1996) obteve valores de ângulo de atrito para solos saprolíticos compactados de granito e biotita, gnaisse, migmatito, e xisto e migmatito, respectivamente, $37^{\circ}, 28^{\circ}, 36^{\circ}$ e $29,5^{\circ}$. 
Quanto à permeabilidade, Mori (1987) afirma que os ensaios de laboratório não representam fielmente a situação de campo, pois como o destorroamento é maior no laboratório, costumase obter coeficientes de permeabilidade maiores in situ. O autor informa, ainda, que valores de permeabilidade esperados para solos saprolíticos compactados são da ordem de $10^{-8} \mathrm{~m} / \mathrm{s}$.

Ferrari (2005) determinou a permeabilidade de campo e laboratório de um silte saprolítico de filito da Região Metropolitana de São Paulo compactado na energia modificada. A permeabilidade determinada in situ por ensaios tipo Matsuo variou entre $3 \times 10^{-8}$ e $2 \times 10^{-7} \mathrm{~m} / \mathrm{s}$. Em ensaios de laboratório realizados com amostras indeformadas retiradas da camada compactada, a permeabilidade variou entre $2 \times 10^{-8}$ e $7 \times 10^{-8} \mathrm{~m} / \mathrm{s}$. Os ensaios realizados com amostras compactadas no laboratório na energia modificada resultaram em coeficientes de permeabilidade de $2 \times 10^{-8}$ a $6 \times 10^{-8} \mathrm{~m} / \mathrm{s}$. Embora a faixa de variação tenha sido maior nos ensaios in situ, as permeabilidades do solo compactado em laboratório e em campo foram da mesma ordem de grandeza.

Em ensaios de permeabilidade com um solo saprolítico de gnaisse compactado na energia normal, Stuermer (2006) não observou grandes variações da permeabilidade em função do teor de umidade, do gradiente hidráulico ou da tensão confinante. O coeficiente de permeabilidade variou de $2,1 \times 10^{-8}$ a $1,1 \times 10^{-7} \mathrm{~m} / \mathrm{s}$ para variações do desvio de umidade de $3 \%$ a $+3 \%$, de tensão confinante de $50 \mathrm{kPa}$ a $150 \mathrm{kPa}$ e gradiente hidráulico de 30 a 100 . Houve redução da permeabilidade para $2,4 \times 10^{-9}$ a $7,1 \times 10^{-9} \mathrm{~m} / \mathrm{s}$ devido à compactação na energia modificada.

Moura e Garcia (1985) mostraram que solos saprolíticos siltosos de filito apresentam maior pressão de expansão quando compactados do que no estado indeformado. Além disso, quando compactados, a pressão de expansão é maior no ramo seco do que no ponto ótimo. Os solos estudados, um sericítico (micáceo) e outro caulínico, continham inexpressiva fração argila: $\mathrm{O}$ solo sericítico, composto de $2 \%$ de argila, $68 \%$ de silte e $30 \%$ de areia, apresentou pressão de expansão de $55 \mathrm{kPa}$ no estado indeformado e $49 \mathrm{kPa}$ quando compactado no ponto ótimo. A pressão de expansão do solo caulínico, composto de $5 \%$ de argila, $80 \%$ de silte e $15 \%$ de areia, foi de $27 \mathrm{kPa}$ no estado indeformado e $110 \mathrm{kPa}$ quando compactado no ponto ótimo. Os autores também salientam o caráter elástico e a expansão mecânica do solo sericítico, uma vez 
que as partículas de mica são dobradas na compactação e tendem a voltar à posição inicial quando a carga é retirada.

Stuermer (2006) observou que, no ponto ótimo, o aumento da energia de compactação aumentou a pressão de expansão, mas não a expansão após o descarregamento (Tabela 3.6). O ensaio foi realizado com inibição de expansão, ou seja, após posicionar a célula de adensamento na prensa, o corpo-de-prova foi inundado e a expansão foi evitada com o uso de pesos, Define-se a pressão de expansão neste caso como sendo a carga total colocada na prensa de adensamento para inibir a expansão do solo. A pressão de expansão do solo compactado pode ser considerada baixa, ou seja, a expansibilidade do solo pode ser contida com baixas cargas.

Tabela 3.6 Resultados de ensaios de expansão de um solo saprolítico de gnaisse (Stuermer, 2006).

\begin{tabular}{ll}
\hline Parâmetro & Valores \\
\hline Pressão de expansão com inibição de expansão (EN) & $20 \mathrm{kPa}$ \\
\% de expansão (EN) & $14,5 \%$ \\
Pressão de expansão com inibição de expansão (EM) & $29 \mathrm{kPa}$ \\
$\%$ de expansão (EM) & $14,0 \%$ \\
\hline
\end{tabular}

Conciani (2006) realizou um ensaio edométrico segundo a NBR 12007 (1990) para obter a pressão de expansão de um silte saprolítico de filito do Município de Cuiabá, MT. O método utilizado foi a medida da expansão livre no início do ensaio: uma vez acrescentada a carga de assentamento das placas de carregamento (cabeçote da prensa), inunda-se a amostra. A norma brasileira NBR 12007 fixa a carga de assentamento em $2 \mathrm{kPa}$. Procede-se então ao ensaio de compressão edométrica usual. A carga necessária para fazer o volume da amostra retornar ao valor inicial é considerada a carga correspondente à pressão de expansão. A curva de compressão obtida encontra-se na Figura 3.4, onde se observa que a pressão de expansão é da ordem de $60 \mathrm{kPa}$. 


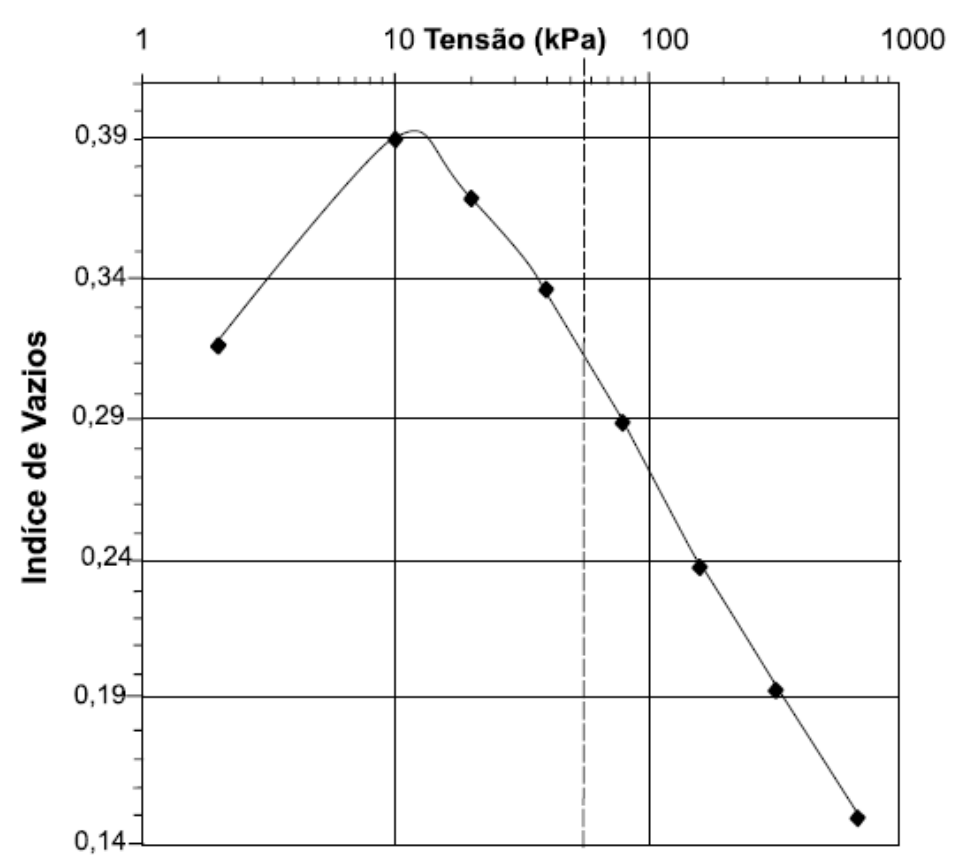

Figura 3.4 Determinação da pressão de expansão de um silte saprolítico de filito de CuiabáMT (Conciani, 2006).

\subsection{MISTURAS SOLO-BENTONITA}

Quando não se consegue obter a permeabilidade de $10^{-9} \mathrm{~m} / \mathrm{s}$ na camada de solo compactado do revestimento de fundo do aterro de resíduos, pode-se utilizar uma mistura de solo com bentonita.

A bentonita é o nome genérico de argila composta predominantemente pelo argilomineral montmorilonita, do grupo das esmectitas, independentemente de sua origem ou ocorrência. As esmectitas possuem como características principais o alto poder de inchamento, até 20 vezes seu volume inicial; alta superfície específica, até $800 \mathrm{~m} / \mathrm{g}$; capacidade de troca catiônica na faixa de 60 a 170 meq/100g e tixotropia. Estas características conferem à bentonita propriedades bastante específicas, que têm justificado uma vasta gama de aplicações nos mais diversos segmentos industriais (DNPM, 2009). As bentonitas são geralmente formadas por cinza vulcânica alterada e/ou sedimentos do magma; porém, apenas algumas cinzas vulcânicas se transformam em bentonitas utilizáveis industrialmente (BENTONIT, 2009).

Segundo o Sumário Mineral (DNPM, 2006), no Brasil há aproximadamente 41,5 milhões de toneladas de reserva de bentonita. O Município de Quatro Barras no Paraná representa 40,3\% das reservas nacionais das argilas bentoníticas, seguido pelos Municípios de Boa Vista e 
Campina Grande, no Estado da Paraíba, com 31,4\% e 28,3\%, respectivamente; em São Paulo há bentonita nos Municípios de Taubaté, Tremembé e Jacareí. A Paraíba é o maior Estado produtor da bentonita, com 91,4\% da produção nacional, seguida por São Paulo, com 8,6\%. No mercado mundial se destacam EUA, Grécia, Turquia e Comunidade dos Estados Independentes (CEI).

Existem bentonitas cálcicas e sódicas, dependendo dos cátions interplanares predominantes. As bentonitas sódicas retiram umidade do meio em que estão e, como conseqüência, expandem, causando um decréscimo da condutividade hidráulica. Portanto, têm sido muito utilizadas como aditivos para materiais com permeabilidade acima do limite máximo especificado para "liners", principalmente para areias.

Recentemente as bentonitas vêm sendo utilizadas nas áreas ambiental e geotécnica devido à sua baixa permeabilidade, elevada plasticidade, elevada capacidade de adsorção e suas qualidades reológicas, como, por exemplo, sua trabalhabilidade (Pitanga, 2007).

Ao se realizar misturas silte-bentonita, entende-se que além da permeabilidade, outras características do solo são modificadas. Segundo Bowles (1977), por exemplo, silte contendo 5 a $8 \%$ de partículas de argila pode mostrar considerável coesão, dependendo do tamanho dos grãos do silte e do tipo de argilo-mineral. Maiores porcentagens resultarão em características argilosas, de modo que um depósito de silte pode ser denominado de "argila" por leigos.

Para se determinar o teor de bentonita necessário, realizam-se ensaios de permeabilidade com misturas de solo e bentonita em diversas proporções. Utiliza-se geralmente o mínimo teor que garanta que o coeficiente de permeabilidade seja igual ou menor do que o exigido.

Aurinko e Kujala (2005), numa pesquisa sobre diversos materiais alternativos para CCLs, utilizaram como material de referência um silte de moraina, compactado na umidade ótima e grau de compactação de $92 \%$ na energia modificada. Realizaram 23 ensaios de permeabilidade com esse material, obtendo coeficientes de permeabilidade entre $2 \times 10^{-8}$ e $3 \times 10^{-10} \mathrm{~m} / \mathrm{s}$, com média igual a $1,8 \times 10^{-9} \mathrm{~m} / \mathrm{s}$. Ao adicionar $2,5 \%$ de bentonita a esta mistura a permeabilidade diminuiu para $46 \%$ da permeabilidade do solo natural e o desvio reduziu a $1 / 10$ do valor original. 
Materiais naturais ou pouco processados podem apresentar maior variabilidade na permeabilidade do que misturas solo-bentonita. Ferrari (2005), por exemplo, realizou o controle de compactação e permeabilidade in situ de dois aterros experimentais, um composto de silte saprolítico (A1), e outro de uma mistura de silte saprolítico com 5\% de bentonita (A2). Os resultados da Tabela 3.7 mostram uma menor variação das propriedades no aterro com a mistura; o coeficiente de permeabilidade, por exemplo, variou cinco vezes, enquanto no aterro de solo variou 10 vezes. $\mathrm{O}$ autor considera que a maior homogeneidade no aterro A2 se deve ao maior cuidado durante o gradeamento e mistura da bentonita.

Tabela 3.7 Propriedades geotécnicas de 2 aterros experimentais (Ferrari, 2005).

\begin{tabular}{cccc}
\hline Aterro & Propriedade & Média & Desvio Padrão \\
\hline \multirow{2}{*}{$\mathrm{A} 1$} & $\gamma_{\mathrm{d}}\left(\mathrm{kN} / \mathrm{m}^{3}\right)$ & 15,4 & 0,3 \\
$\mathrm{w}(\%)$ & 23,4 & 0,6 \\
& $\mathrm{GC}(\%)$ & 91,7 & 1,8 \\
& $\Delta \mathrm{w}(\%)$ & 2,6 & 0,6 \\
$\mathrm{k}(\mathrm{m} / \mathrm{s})$ & \multicolumn{2}{c}{$2,8 \times 10^{-8} \mathrm{a} 2,2 \times 10^{-7}$} \\
\hline \multirow{2}{*}{$\mathrm{A} 2$} & $\gamma_{\mathrm{d}}\left(\mathrm{kN} / \mathrm{m}^{3}\right)$ & 16,5 & 0,1 \\
$\mathrm{w}(\%)$ & 20,2 & 0,1 \\
& $\mathrm{GC}(\%)$ & 96,1 & 0,5 \\
& $\Delta \mathrm{w}(\%)$ & 2,6 & 0,1 \\
$\mathrm{k}(\mathrm{m} / \mathrm{s})$ & \multicolumn{2}{c}{$5,8 \times 10^{-9} \mathrm{a} 2,0 \times 10^{-8}$}
\end{tabular}

$\gamma_{\mathrm{d}}=$ peso específico aparente seco, $\mathrm{w}=$ teor de umidade, $\mathrm{GC}=$ grau de compactação, $\Delta \mathrm{w}=$ desvio de umidade em relação à ótima, $\mathrm{k}=$ coeficiente de permeabilidade

Tripathi e Viswanadham (2005) citam trabalhos de outros autores em que a distribuição de bentonita é melhor para maiores teores de umidade nas misturas areia-bentonita, porém este efeito não é significativo para misturas argila-bentonita.

No trabalho de Aurinko e Kujala (2005), apesar do decréscimo da permeabilidade e da melhora no desvio decorrentes da adição de bentonita, ainda alguns valores ultrapassaram o limite de $10^{-9} \mathrm{~m} / \mathrm{s}$. O teor de bentonita poderia ser aumentado, ou, segundo os autores, as especificações deveriam incluir desvios aceitáveis para os diversos materiais. Os autores dividem os fatores de erros no ensaio de permeabilidade em erros humanos e erros devidos a equipamento e amostragem. O tamanho da célula restringe o diâmetro da amostra, o qual, por 
sua vez, deve ser 6 vezes maior que a máxima partícula do material (ASTM D5084/2003). Devido às dimensões dos permeâmetros, os corpos-de-prova de ensaios de permeabilidade geralmente têm diâmetro máximo de $150 \mathrm{~mm}$, o que limita a máxima partícula do solo a 25 mm. Muitos materiais que em campo apresentam partículas maiores estarão mal representados nos ensaios de laboratório. Ademais, os anéis de borracha (O-rings) sob a pressão confinante por um longo tempo podem trincar e causar infiltração entre amostra e o equipamento. Aurinko e Kujala (2005) chamam também a atenção para a heterogeneidade dos corpos-de-prova devido à presença de agregados, causando um fluxo não homogêneo através do solo. O tempo para normalizar o fluxo também depende do material ensaiado: misturas com bentonita demoram mais a normalizar devido à expansão da bentonita.

Os ensaios de permeabilidade com misturas solo-bentonita para determinar o mínimo teor de bentonita que garanta permeabilidade menor ou igual a $1 \times 10^{-9} \mathrm{~m} / \mathrm{s}$ requerem longo tempo, geralmente meses, para estabilizar, dependendo do tipo de permeâmetro (parede rígida ou flexível) e qualidade da amostra (grau de saturação inicial, teor de bentonita, densidade seca da mistura, etc.). O valor da permeabilidade muda devido ao aumento do grau de saturação e do volume da bentonita hidratada com o tempo.

Tripathi e Viswanadham (2005) propõem um método para determinar o teor ótimo de bentonita para misturas areia-bentonita em 6 semanas. Foram realizados diversos ensaios com misturas de areia-bentonita, moldados na energia normal. A areia era uniforme com $\mathrm{D}_{10}$ igual a $0,17 \mathrm{~mm}, \mathrm{CNU}$ de 1,76, CC de 1,03, e coeficiente de permeabilidade no estado denso de $2,3 \times 10^{-4} \mathrm{~m} / \mathrm{s}$. O aditivo era uma bentonita sódica comercialmente disponível, de LL igual a $395 \%$ e LP igual a 42\%. Misturas de 5, 10, 15, 20 e 25\% de bentonita foram submetidas a ensaios de permeabilidade de carga variável e parede rígida. As amostras ficaram sujeitas a um processo de saturação por 2 semanas anteriormente ao ensaio de permeabilidade. $O$ gradiente variou entre 10 e 15 ao longo dos ensaios. A Tabela 3.8 mostra a variação do coeficiente de permeabilidade medido ao longo do tempo. 
Tabela 3.8 Coeficiente de permeabilidade $(\mathrm{m} / \mathrm{s})$ em função do tempo de ensaio e do teor de bentonita (Tripathi e Viswanadham, 2005).

\begin{tabular}{ccc}
\cline { 2 - 3 } Tempo (dias) & \multicolumn{2}{c}{ Teor de bentonita } \\
\cline { 2 - 3 } & $\mathbf{5 \%}$ & $\mathbf{1 0 \%}$ \\
\hline 10 & $1,3 \times 10^{-9}$ & $6,4 \times 10^{-11}$ \\
60 & $6,6 \times 10^{-10}$ & $5,0 \times 10^{-11}$ \\
180 & $9,2 \times 10^{-10}$ & $7,3 \times 10^{-11}$ \\
240 & $1,1 \times 10^{-9}$ & $7,9 \times 10^{-11}$ \\
300 & $1,2 \times 10^{-9}$ & $8,3 \times 10^{-11}$ \\
\hline
\end{tabular}

Esses valores apresentados sob a forma de curvas de coeficiente de permeabilidade em função de tempo (Figura 3.5) mostram que a permeabilidade medida decresce inicialmente e depois de algum tempo a alteração é desprezível.

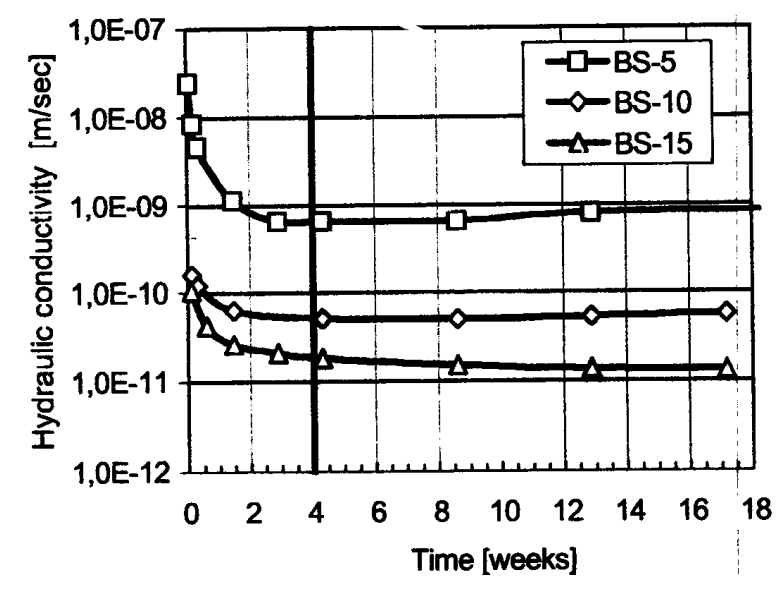

(a)

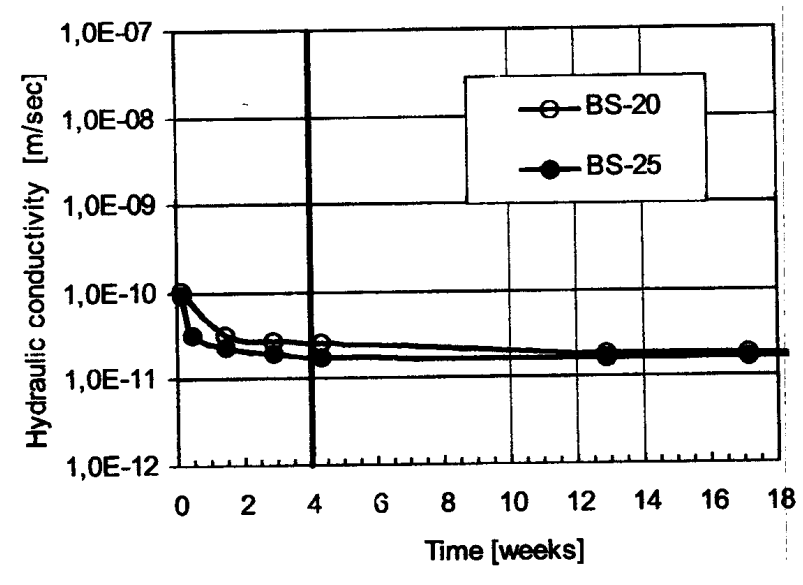

(b)

Figura 3.5 Condutividade hidráulica em função do tempo de ensaio: (a) misturas com 5\%, $10 \%$ e $15 \%$ de bentonita; (b) misturas com $20 \%$ e $25 \%$ de bentonita (Tripathi e Viswanadham 2005).

O tempo para estabilizar a permeabilidade foi de cerca de 4 semanas. Os valores atingidos neste período pouco diferem daqueles obtidos após 250 a 300 dias. Já os autores consideram essas diferenças significativas e recomendam um fator de segurança para a permeabilidade de curto prazo (4 semanas). A Figura 3.6 mostra o coeficiente de permeabilidade em função do teor de bentonita para 4 semanas e para 300 dias. 


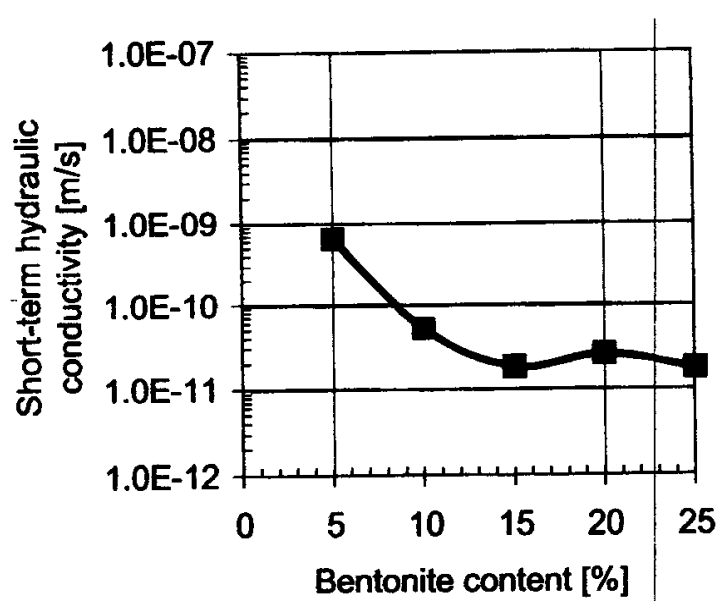

(a)

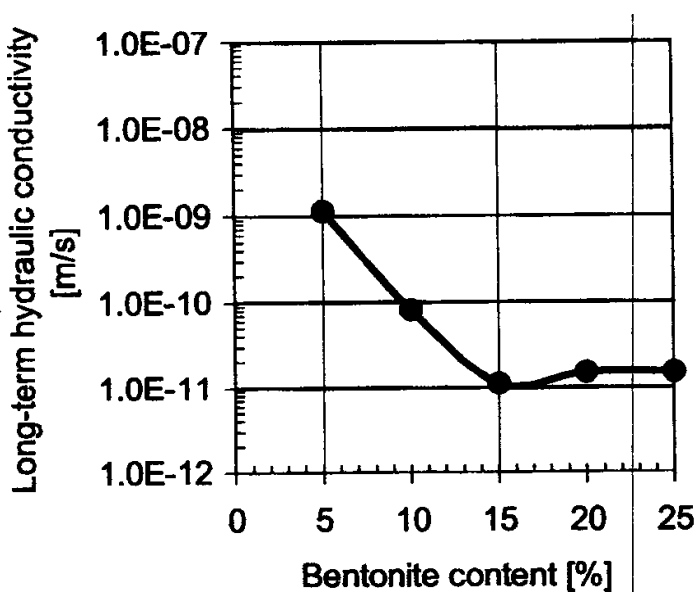

(b)

Figura 3.6 Coeficiente de permeabilidade em função do teor de bentonita: (a) 4 semanas de ensaio; (b) 300 dias de ensaio (Tripathi e Viswanadham 2005).

Para obter valor da permeabilidade menor ou igual a $1 \times 10^{-9} \mathrm{~m} / \mathrm{s}$, o teor de bentonita de $5 \%$ foi suficiente, tanto considerando a permeabilidade de 4 semanas como a permeabilidade de 300 dias. O coeficiente de permeabilidade decresce para teores de bentonita de $5 \%$ a $15 \%$, chegando a valores de $1 \times 10^{-11} \mathrm{~m} / \mathrm{s}$. Teores maiores de bentonita não influem mais na permeabilidade. Os autores, contudo, consideram que o teor a ser adotado deve ser aquele que em 4 semanas apresente um coeficiente de permeabilidade menor ou igual a $10^{-10} \mathrm{~m} / \mathrm{s}$ para garantir que o valor de $10^{-9} \mathrm{~m} / \mathrm{s}$ não seja ultrapassado em longo prazo. A alteração na permeabilidade, porém, é desprezível em função do tempo após 4 semanas, segundo os resultados apresentados na Figura 3.5 e Figura 3.6. Teria sido interessante, por outro lado, realizar ensaios com percolação de lixiviado.

Lukiantchuki e Esquivel (2007) analisaram a influência do teor de bentonita na permeabilidade e na resistência ao cisalhamento de uma areia argilosa do Estado de São Paulo, encontrando valores de condutividade hidráulica da ordem de $10^{-9} \mathrm{~m} / \mathrm{s}$ para solo com $5 \%$ de bentonita, conforme apresentado na Figura 3.7. O tempo da execução do ensaio de permeabilidade foi de aproximadamente 250 minutos, inferior ao encontrado na literatura. A variação da condutividade hidráulica com o tempo está apresentada na Figura 3.8. 


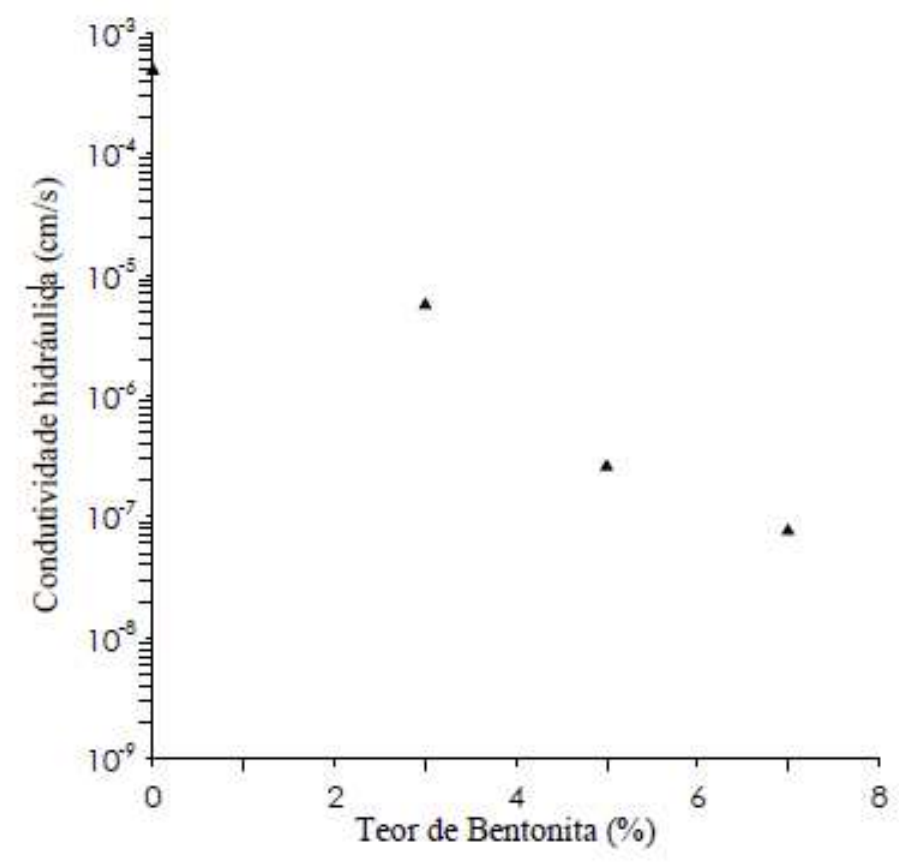

Figura 3.7 Variação da condutividade hidráulica, em $\mathrm{cm} / \mathrm{s}$, em função do teor de bentonita (Lukiantchuki e Esquivel, 2007).

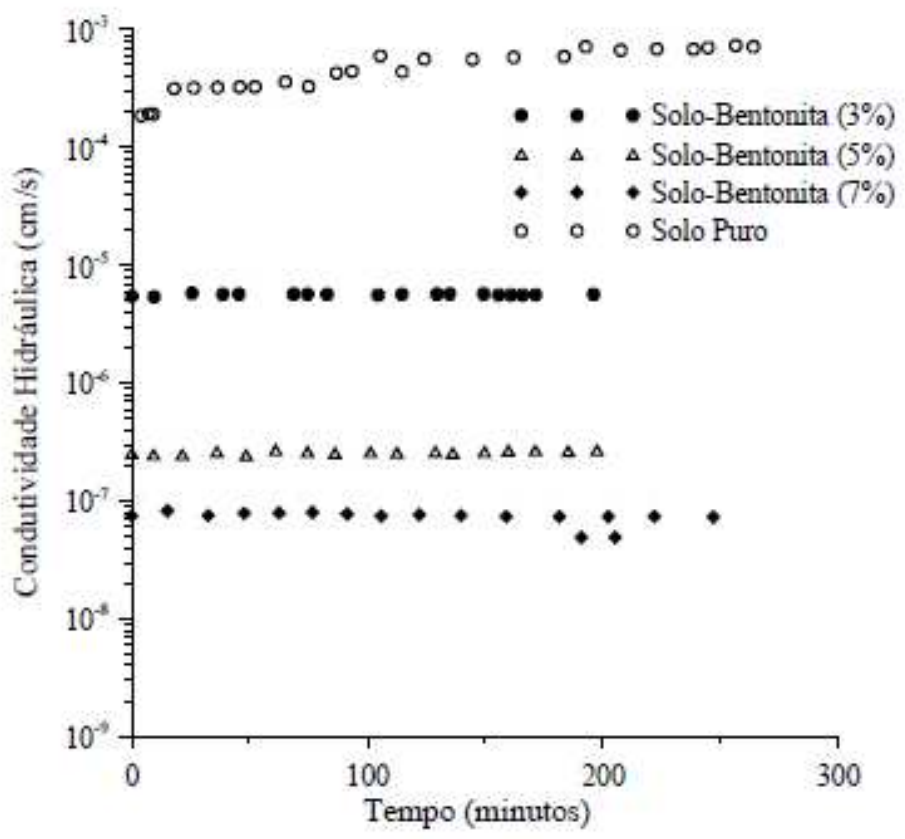

Figura 3.8 Variação da condutividade hidráulica, em $\mathrm{cm} / \mathrm{s}$, em função do tempo, para corpos de prova de solo puro e solo-bentonita, após a saturação (Lukiantchuki e Esquivel, 2007).

Os resultados dos ensaios de resistência ao cisalhamento, conforme Tabela 3.9, demonstram um aumento da coesão efetiva e uma redução do ângulo de atrito efetivo das misturas em 
relação ao solo sem bentonita, devidos ao aumento de finos gerado pela adição de bentonita e ao baixo grau de compactação dos corpos-de-prova, respectivamente.

Tabela 3.9 Parâmetros de resistência ao cisalhamento (Lukiantchuki e Esquível, 2007).

\begin{tabular}{ccccc}
\hline \multirow{2}{*}{$\begin{array}{c}\text { Teor de } \\
\text { bentonita }(\%)\end{array}$} & \multicolumn{2}{c}{ Parâmetros totais } & \multicolumn{2}{c}{ Parâmetros efetivos } \\
\cline { 2 - 5 } & $\mathbf{c}(\mathbf{k P a})$ & $\boldsymbol{\emptyset}\left({ }^{\mathbf{9}}\right)$ & $\mathbf{c}^{\prime}(\mathbf{k P a})$ & $\boldsymbol{\emptyset}^{\mathbf{\prime}}\left({ }^{\mathbf{o}}\right)$ \\
\hline 0 & 16,1 & 8,4 & 13,7 & 19,4 \\
3 & 11,9 & 6,7 & 14,4 & 13,4 \\
5 & 15,1 & 6,3 & 15,7 & 11,3 \\
7 & 17,6 & 7,2 & 14,4 & 15,5 \\
\hline
\end{tabular}

A adição de bentonita modifica a curva de compactação. Kenney et al. (1992) observaram um aumento do peso específico aparente seco máximo para areias, enquanto Mizuno et al. (2005) observaram diminuição do peso específico aparente seco máximo e aumento do teor de umidade ótimo para elevados teores de bentonita adicionados a uma areia siltosa de granito decomposto, conforme exemplifica a Figura 3.9, onde estão apresentadas curvas de compactação para o solo natural e para teores de bentonita $(\mathrm{B} / \mathrm{S})$ de $11 \%, 18 \%, 38 \%$ e $50 \%$. Para o teor de bentonita de $11 \%$, no entanto, o peso específico aparente seco aumentou.

Mizuno et al. (2005) também determinaram por meio de ensaios laboratoriais o efeito da bentonita na condutividade hidráulica e na resistência à penetração do cone (norma britânica BS1377:1990 - Methods of test for soils for civil engineering purposes) para diversas densidades secas e teores de umidade para uma areia siltosa com adição de $13 \%$ de bentonita, com o intuito de determinar especificações de controle de compactação. Os resultados na Figura 3.9 mostram que devido à adição de alto teor de bentonita a permeabilidade fica abaixo da requerida mesmo para teores de umidade abaixo do ótimo. Os autores também controlaram o teor de bentonita, teor de umidade e densidade seca de "liners" de 10 aterros de resíduos construídos no Japão, observando que as especificações da Figura 3.10 puderam ser atendidas em campo. 


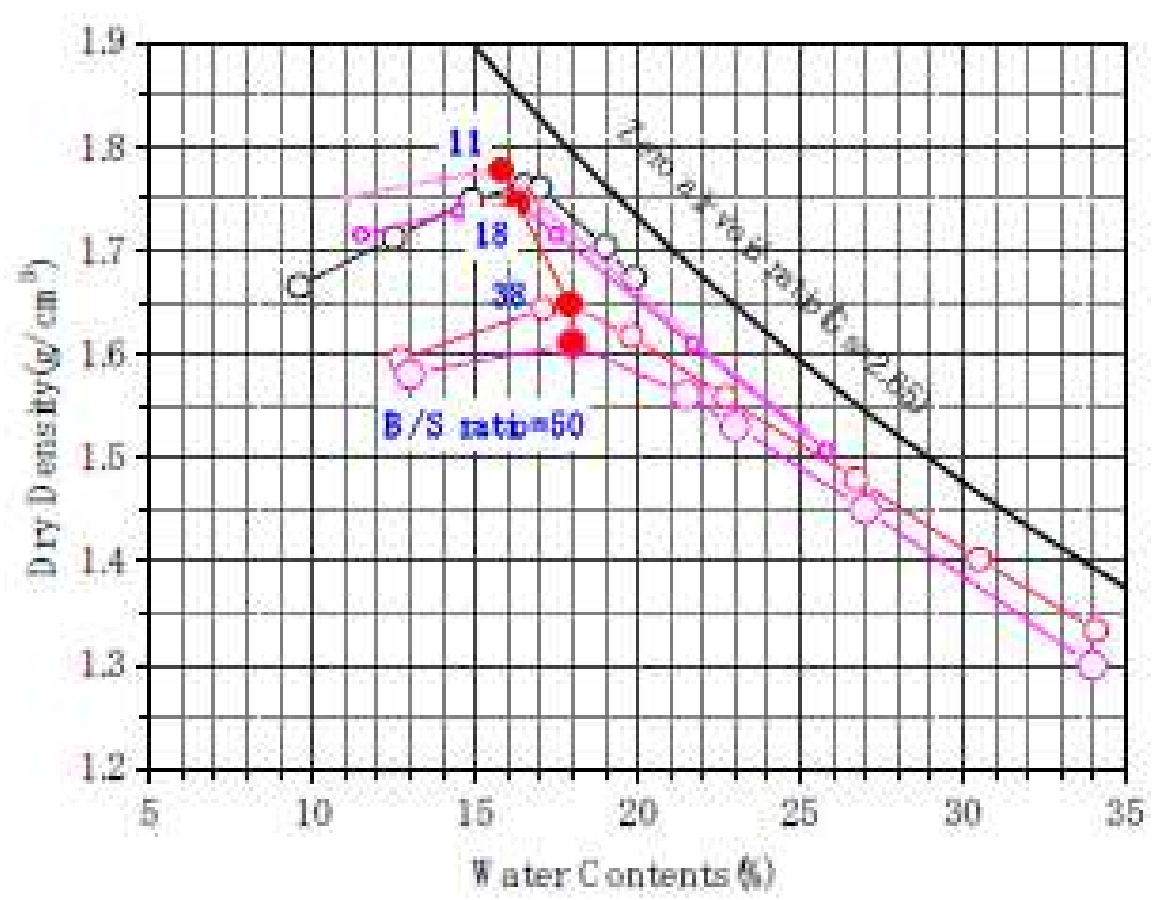

Figura 3.9 Curvas de compactação para misturas solo-bentonita com diversos teores de bentonita (Mizuno et al., 2005).

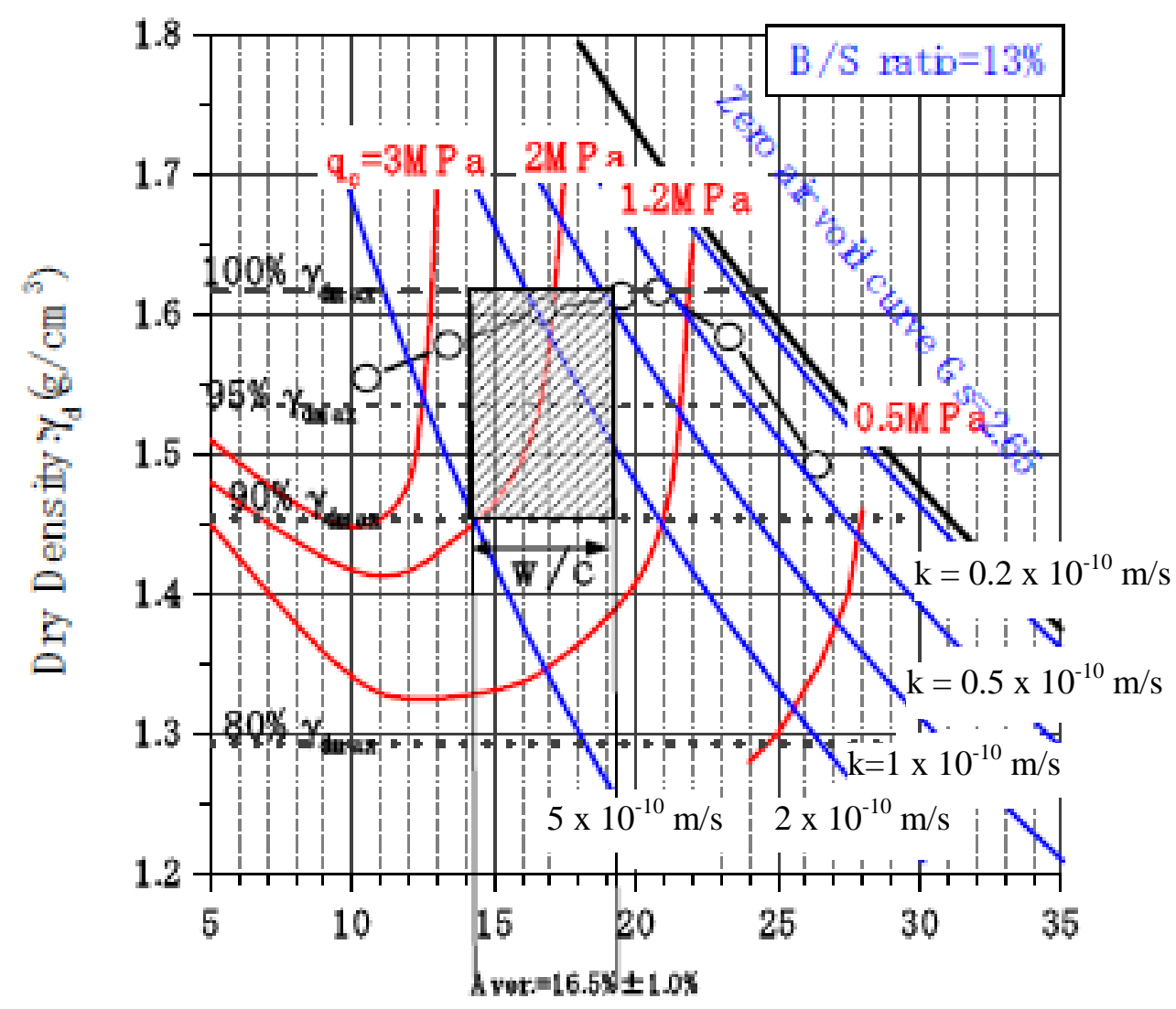

$\mathrm{k}=$ coeficiente de permeabilidade, $\mathrm{q}_{\mathrm{c}}=$ resistência à penetração do cone

Figura 3.10 Especificação para controle de compactação em campo (Mizuno et al., 2005). 
Quando um solo misturado com bentonita é usado para contenção em barreiras ambientais, é importante que sua condutividade hidráulica permaneça em um nível aceitável após exposição aos contaminantes. A exposição a contaminantes será problemática se ela produzir retração, provocando caminhos preferenciais de fluxo através da mistura (Studds, 1997). Portanto, após determinar o teor de bentonita necessário para a construção de um "liner", é necessário verificar se as propriedades do mesmo se mantêm ao longo de tempo, mesmo que ocorra contato com o lixiviado.

\subsection{INTERAÇÃO ENTRE SOLO E LIXIVIADO}

Lixiviado, percolado, chorume, sumeiro ou chumeiro é um líquido resultante dos processos biológicos, químicos e físicos que causam a decomposição de resíduos orgânicos, gerado em massas de resíduos sólidos urbanos. Possui cor escura, odor desagradável e alta carga poluidora, devido à alta concentração de matéria orgânica, reduzida biodegradabilidade, presença de metais pesados e de substâncias recalcitrantes. Alguns autores diferenciam o termo chorume como o produto da decomposição dos materiais orgânicos e percolado ou lixiviado como a mistura do chorume com os líquidos que infiltram na massa dos resíduos.

Iwai (2005) define chorume como sendo a parte líquida da massa de resíduos aterrada, que ao percolar remove materiais dissolvidos ou suspensos da referida massa de resíduos, lembrando que na maioria dos aterros sanitários, o lixiviado é gerado por fontes externas. Segundo IPT/CEMPRE (2000), chorume é um líquido de composição bastante variável que adquiriu características poluentes devido ao seu contato com a massa de resíduos sólidos em decomposição. Boscov (2005) descreve o chorume como sendo um fluido efluente da massa de resíduos resultante da percolação de águas de precipitação e da própria decomposição dos resíduos. Este fluido possui características químicas muito variáveis, pois depende tanto do resíduo sólido que o originou, como da degradação que o mesmo sofreu. A norma brasileira ABNT NBR 15849:2010 "Resíduos sólidos urbanos - Aterros sanitários de pequeno porte Diretrizes para localização, projeto, implantação, operação e encerramento" adota o termo lixiviado para o efluente gerado no maciço sanitário. 
O lixiviado é um efluente quimicamente complexo, que possui características particulares para cada aterro (Moura et al., 2009). Sua composição depende de fatores como (Bassani et al., 2009; Souto, 2009):

- Fatores climatológicos: precipitação pluviométrica, temperatura, etc.;

- Características dos resíduos: composição, densidade e umidade;

- Disposição: permeabilidade, profundidade e idade do aterro;

- Operação do aterro: eficiência do sistema de drenagem, localização da frente de descarga, compactação, recirculação de chorume, qualidade da impermeabilização da base, entre outros;

- Pré-tratamento dos resíduos: trituração, compostagem, entre outros.

Buscando determinar as características do lixiviado brasileiro, Souto (2009) salienta que no Brasil a fase ácida ocorre em até 2 anos de existência do aterro, considerando a existência de drenagem de base, a partir da qual inicia-se a fase metanogênica.

Tchobanoglous et al. (1993) apud Iwai (2005) informam que durante a fase ácida, o lixiviado apresenta baixos valores de potencial hidrogeniônico $(\mathrm{pH})$ e valores elevados de DBO, DQO, carbono orgânico total (COT), nutrientes e metais pesados. Já durante a fase metanogênica, apresenta valores de $\mathrm{pH}$ variando entre 6,5 e 7,5 e valores menores de DBO, COT, DQO e nutrientes.

A Tabela 3.10 e a Tabela 3.11 apresentam os resultados da compilação e processamento dos dados de lixiviados de 56 aterros brasileiros realizados por Souto (2009). A distribuição desses aterros nas regiões brasileiras encontra-se na Figura 3.11. 


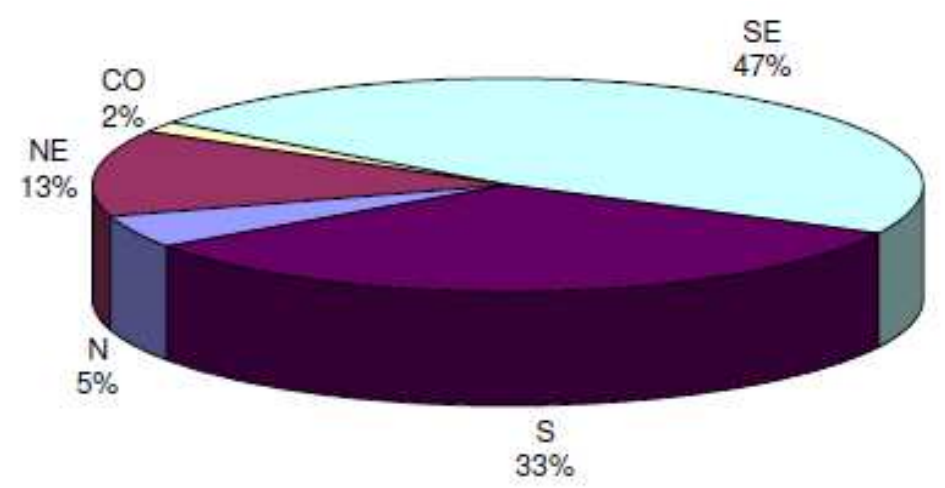

Figura 3.11 Distribuição por região dos aterros cujos dados de lixiviado foram compilados (Souto, 2009).

A Tabela 3.10 se refere às características da fase ácida e a Tabela 3.11, da fase metanogênica. Os valores dos percentis 10 e $20 \%$ significam que em 90 ou $80 \%$ dos aterros a variável em questão assume valores acima do limite apresentado. Já os percentis 80 e $90 \%$ indicam que em 80 ou $90 \%$ dos aterros a variável assume valores abaixo do limite apresentado. O autor ressalta a importância do real significado dessas probabilidades: "O percentil 10\%, por exemplo, indica que em $90 \%$ dos aterros os valores da variável em questão estarão acima desse limite. Isso não é o mesmo que dizer que, num dado aterro, em 90\% do tempo os valores estarão acima daquele limite. Para tal seria preciso dispor das séries temporais de longo prazo para um grande número de aterros, o que é raro na bibliografia nacional. É muito provável que as faixas típicas de variação dentro de um mesmo aterro tenham uma amplitude bem menor que as apresentadas nestas tabelas" (Souto, 2009). 
Tabela 3.10 Características típicas do lixiviado dos aterros brasileiros na fase ácida (Souto, 2009).

\begin{tabular}{|c|c|c|c|c|c|c|c|}
\hline Variável & Mínimo & $10 \%$ & $20 \%$ & $80 \%$ & $90 \%$ & Máximo & Ref.* \\
\hline $\mathrm{pH}$ & 4,4 & 4,8 & 5,1 & 8,3 & 8.3 & 8,4 & 13 \\
\hline $\begin{array}{l}\text { Alcalinidade total } \\
\left(\mathrm{mg} / \mathrm{L} \text { de } \mathrm{CaCO}_{3}\right)\end{array}$ & 170 & & 460 & 25000 & & 32000 & 7 \\
\hline Turbidez (UNT) & 100 & & & & & 540 & 1 \\
\hline Condutividade $(\mu \mathrm{S} / \mathrm{cm})$ & 230 & & & & & 45000 & 4 \\
\hline $\mathrm{DBO}\left(\mathrm{mg} / \mathrm{L}\right.$ de $\left.\mathrm{O}_{2}\right)$ & 1 & 15 & 35 & 25400 & 29800 & 55000 & 12 \\
\hline $\mathrm{DQO}\left(\mathrm{mg} / \mathrm{L}\right.$ de $\left.\mathrm{O}_{2}\right)$ & 90 & 180 & 540 & 53700 & 74000 & 100000 & 13 \\
\hline $\operatorname{NTK}(\mathrm{mg} / \mathrm{L}$ de $\mathrm{N})$ & 1,7 & & & & & 3000 & 4 \\
\hline NAT (mg/L de N) & 0,07 & & 10 & 1800 & & 2000 & 9 \\
\hline $\mathrm{N}-\mathrm{NO}_{2}^{-}(\mathrm{mg} / \mathrm{L}$ de $\mathrm{N})$ & - & - & - & - & - & - & 0 \\
\hline $\mathrm{N}-\mathrm{NO}_{3}{ }^{-}(\mathrm{mg} / \mathrm{L}$ de $\mathrm{N})$ & nd & & & & & 45 & 3 \\
\hline P-total (mg/L de $\mathrm{P})$ & nd & & nd & 107 & & 260 & 5 \\
\hline Cloreto $(\mathrm{mg} / \mathrm{L})$ & 275 & & & & & 4700 & 2 \\
\hline $\mathrm{ST}(\mathrm{mg} / \mathrm{L})$ & 400 & & 1000 & 39300 & & 45000 & 7 \\
\hline $\mathrm{STV}(\mathrm{mg} / \mathrm{L})$ & 78 & & 260 & 21800 & & 26700 & 6 \\
\hline $\mathrm{STF}(\mathrm{mg} / \mathrm{L})$ & 40 & & & & & 28400 & 4 \\
\hline $\mathrm{SST}(\mathrm{mg} / \mathrm{L})$ & 10 & & & & & 7000 & 4 \\
\hline Fe total $(\mathrm{mg} / \mathrm{L})$ & nd & & 0,004 & 500 & & 1400 & 8 \\
\hline $\mathrm{Cd}$ total $(\mathrm{mg} / \mathrm{L})$ & nd & & nd & 0,09 & & 0,1 & 7 \\
\hline $\mathrm{Cu}(\mathrm{mg} / \mathrm{L})$ & nd & & nd & 0,5 & & 0,8 & 7 \\
\hline $\mathrm{Cr}(\mathrm{mg} / \mathrm{L})$ & nd & & nd & 0,6 & & 1,2 & 5 \\
\hline $\mathrm{Mn}$ total $(\mathrm{mg} / \mathrm{L})$ & nd & & & & & 115 & 4 \\
\hline $\mathrm{Ni}(\mathrm{mg} / \mathrm{L})$ & nd & & & & & 6.5 & 4 \\
\hline $\mathrm{Zn}(\mathrm{mg} / \mathrm{L})$ & nd & & nd & 7 & & 27 & 7 \\
\hline $\mathrm{Pb}$ total $(\mathrm{mg} / \mathrm{L})$ & nd & & nd & 1,3 & & 1,5 & 6 \\
\hline $\mathrm{CT}(\mathrm{NMP} / 100 \mathrm{~mL})$ & 200 & & & & & $5 \times 10^{7}$ & 1 \\
\hline
\end{tabular}

OBS: ${ }^{*}$ Ref $=\mathrm{n}^{\circ}$ de referências das quais se obteve dados para a variável; $\mathrm{nd}=$ abaixo do limite de detecção; CT $=$ coliformes termotolerantes 
Tabela 3.11 Características típicas do lixiviado dos aterros brasileiros na fase metanogênica (Souto, 2009).

\begin{tabular}{|c|c|c|c|c|c|c|c|}
\hline Variável & Mínimo & $10 \%$ & $20 \%$ & $80 \%$ & $90 \%$ & Máximo & Ref.: \\
\hline $\mathrm{pH}$ & 5,9 & 6,8 & 7,1 & 8,7 & 8,8 & 9,2 & 32 \\
\hline $\begin{array}{l}\text { Alcalinidade total } \\
\left(\mathrm{mg} / \mathrm{L} \text { de } \mathrm{CaCO}_{3}\right)\end{array}$ & 125 & 200 & 425 & 11900 & 15800 & 20200 & 19 \\
\hline Turbidez (UNT) & 0,02 & 4,5 & 6 & 540 & 550 & 620 & 11 \\
\hline $\begin{array}{l}\text { Condutividade } \\
(\mu \mathrm{S} / \mathrm{cm})\end{array}$ & 100 & 1850 & 2520 & 25600 & 29400 & 45000 & 23 \\
\hline $\mathrm{DBO}\left(\mathrm{mg} / \mathrm{L}\right.$ de $\left.\mathrm{O}_{2}\right)$ & 3 & 30 & 60 & 6000 & 9300 & 17200 & 30 \\
\hline $\mathrm{DQO}\left(\mathrm{mg} / \mathrm{L}\right.$ de $\left.\mathrm{O}_{2}\right)$ & 20 & 400 & 700 & 13500 & 18600 & 35000 & 34 \\
\hline NTK (mg/L de N) & 0,6 & 20 & 90 & 3000 & 3200 & 5000 & 13 \\
\hline NAT (mg/L de N) & 0,03 & 20 & 50 & 2400 & 2800 & 3000 & 29 \\
\hline $\mathrm{N}-\mathrm{NO}_{2}^{-}(\mathrm{mg} / \mathrm{L})$ & nd & nd & nd & 20 & 40 & 70 & 11 \\
\hline $\mathrm{N}-\mathrm{NO}_{3}^{-}(\mathrm{mg} / \mathrm{L})$ & nd & nd & nd & 60 & 100 & 270 & 15 \\
\hline P-total (mg/L) & nd & 0,1 & 0,2 & 40 & 50 & 80 & 19 \\
\hline Cloreto $(\mathrm{mg} / \mathrm{L})$ & 20 & 50 & 330 & 4100 & 4700 & 6900 & 17 \\
\hline $\mathrm{ST}(\mathrm{mg} / \mathrm{L})$ & 200 & 900 & 1450 & 19100 & 20000 & 29000 & 23 \\
\hline $\operatorname{STV}(\mathrm{mg} / \mathrm{L})$ & 75 & 400 & 600 & 8700 & 10600 & 20000 & 20 \\
\hline $\mathrm{STF}(\mathrm{mg} / \mathrm{L})$ & 100 & 650 & 900 & 12300 & 13800 & 17000 & 15 \\
\hline $\mathrm{SST}(\mathrm{mg} / \mathrm{L})$ & 7 & 10 & 15 & 2600 & 2900 & 12400 & 17 \\
\hline Fe total (mg/L) & 0,01 & 0,25 & 0,40 & 80 & 100 & 720 & 19 \\
\hline $\mathrm{Cd}$ total $(\mathrm{mg} / \mathrm{L})$ & nd & nd & nd & 0,1 & 0,2 & 0,6 & 19 \\
\hline $\mathrm{Cu}(\mathrm{mg} / \mathrm{L})$ & nd & nd & nd & 1,1 & 1,5 & 2,9 & 17 \\
\hline $\mathrm{Cr}(\mathrm{mg} / \mathrm{L})$ & nd & nd & 0,006 & 0,8 & 0,9 & 1,0 & 19 \\
\hline Mn total $(\mathrm{mg} / \mathrm{L})$ & nd & 0,01 & 0,025 & 10 & 20 & 30 & 14 \\
\hline $\mathrm{Ni}(\mathrm{mg} / \mathrm{L})$ & nd & nd & nd & 0,8 & 1,0 & 1,4 & 14 \\
\hline $\mathrm{Zn}(\mathrm{mg} / \mathrm{L})$ & nd & 0,01 & 0,01 & 2 & 5 & 35 & 21 \\
\hline $\mathrm{Pb}$ total $(\mathrm{mg} / \mathrm{L})$ & nd & nd & nd & 1,1 & 2,1 & 6,7 & 18 \\
\hline $\begin{array}{l}\text { CT } \\
(\mathrm{NMP} / 100 \mathrm{~mL})\end{array}$ & nd & nd & 1,6 & $2 \times 10^{7}$ & $6 \times 10^{7}$ & $2 \times 10^{8}$ & 10 \\
\hline
\end{tabular}

OBS: *Ref $=n^{0}$ de referências das quais se obteve dados para a variável; $n d=$ abaixo do limite de deteç̧ào; $C T$ $=$ coliformes termotolerantes

Evitar que o lixiviado contamine o subsolo e o lençol freático, haja vista a composição apresentada na Tabela 3.10 e Tabela 3.11, é a função do "liner" em um aterro sanitário. Para isso, é necessário que haja garantia de seu desempenho mesmo após o contato com o lixiviado. Knopp et al. (2007) observam que as normas atualmente existentes não exigem que os ensaios para a verificação de adequabilidade de um "liner" sejam realizados com o lixiviado de campo ou solução sintética semelhante. Assim, normalmente, o ensaio é realizado com água, o que não representa o comportamento real do sistema.

Diversos autores, estudando variações da permeabilidade em camadas compactadas de argila, concluíram que a permeabilidade do solo pode aumentar quando exposto a lixiviados oriundos de áreas de disposição de resíduos (Nascentes, 2006). Porém esta conclusão não 
pode ser generalizada, visto que as interações solo-lixiviado dependerem de muitos mecanismos.

Hamada et al. (2004), realizando ensaios de coluna com infiltração de lixiviado em solo arenoso típico de Bauru, composto por $67 \%$ de areia fina, $18 \%$ de argila, $8 \%$ de silte e $7 \%$ de areia média, compactado em cinco diferentes graus de compactação $(75 \%, 80 \%, 85 \%$ 90\% e 95\% da energia normal), perceberam redução na permeabilidade do solo, inclusive com atenuação da carga de contaminantes do lixiviado, devido à interação solo-chorume e às reações físico-quimicas, para graus de compactação superiores a 85\%. A redução na permeabilidade foi observada pela comparação do volume efluente das colunas com água e com lixiviado. Os autores consideram que tal fato demonstra a susceptibilidade de colmatação do solo estudado com graus de compactação maiores ou iguais a $85 \%$, promovida pelas partículas em suspensão e pelo desenvolvimento provável de flocos e partículas biológicas

Iwai (2005) realizou ensaios de coluna utilizando o solo ensaiado por Hamada et al. (2004) com graus de compactação de 80, 85, 90, 95 e 100\% da energia normal. Empregaram-se um lixiviado que se encontrava na fase metanogênica (10 anos) e um lixiviado de aterro recente. O autor confirmou as conclusões de Hamada et al. (2004): quanto maior o grau de compactação, menor era a velocidade de escoamento e mais rápida era a colmatação.

Nascentes (2006) também observou redução de permeabilidade devido à interação com contaminantes em oito ensaios de coluna realizados com água (de chuva e destilada) e com contaminantes (solução sintética contaminante de metais pesados geralmente presentes em lixiviados de aterro sanitário), obtendo as curvas de permeabilidade em função do número de volumes de poros percolados (T) apresentadas na Figura 3.12 e Figura 3.13. Informa-se que o material utilizado neste estudo possui $47 \%$ de areia e $42 \%$ de argila, LL $=52 \%$ e $\mathrm{LP}=30 \%$, sendo classificado, conforme o Sistema Unificado de Classificação de Solos, como uma argila de alta plasticidade $(\mathrm{CH})$. 


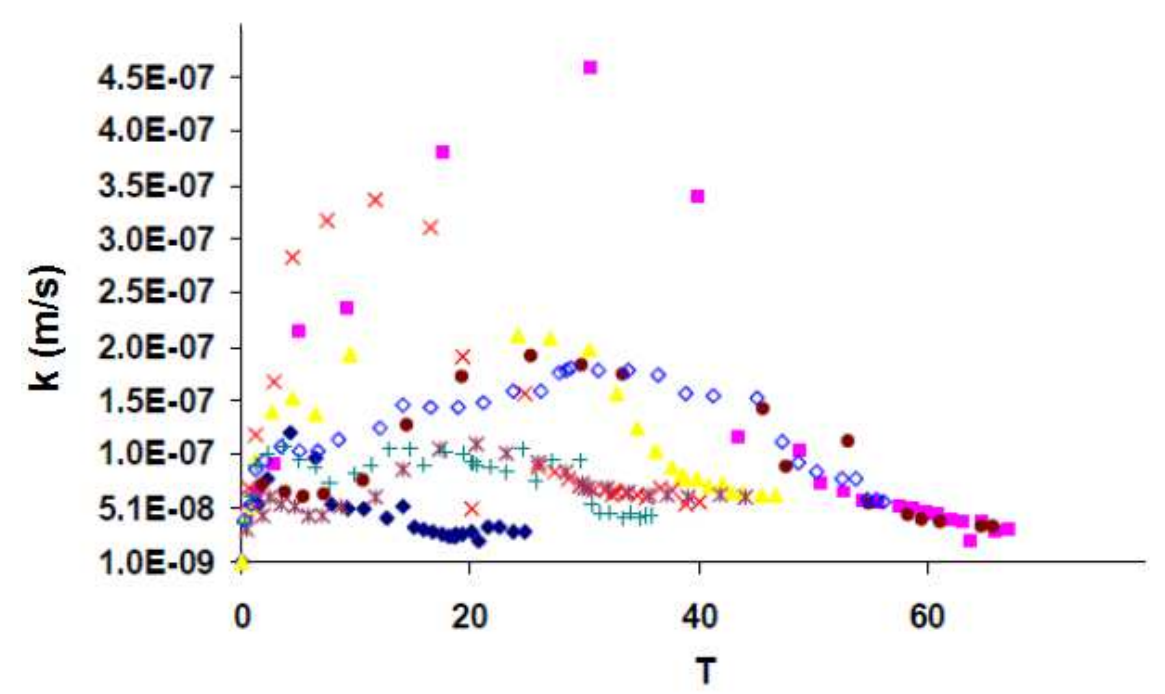

Figura 3.12 Permeabilidade de uma argila arenosa com água (Nascentes, 2006).

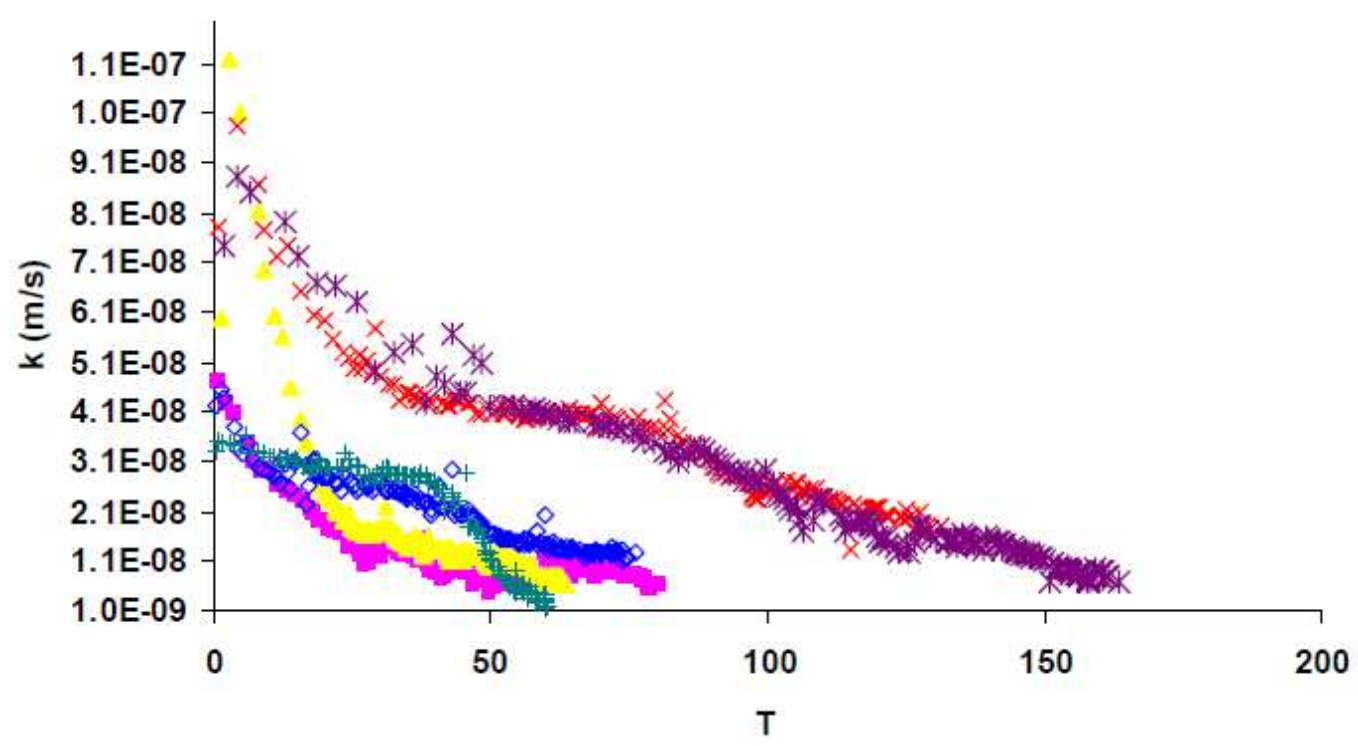

Figura 3.13 Permeabilidade de uma argila arenosa com contaminante (Nascentes, 2006).

Ensaios de permeabilidade de longo prazo foram realizados por Francisca e Glatstein (2010) com um solo areno-siltoso transportado por ação eólica da planície Chaco-pampeana na Argentina. O solo apresenta $\mathrm{LL}=27 \%, \mathrm{IP}=3 \%$ e coeficiente de permeabilidade de $10^{-8} \mathrm{~m} / \mathrm{s}$ após compactação. Os autores ensaiaram misturas do solo com diversos teores de bentonita compactadas no ramo úmido, sob gradiente hidráulico entre 2,1 a 6,5 e inundadas com água destilada (DW), solução nutritiva (NS) e chorume (LL), cuja composição química está informada na Tabela 3.12. O coeficiente de permeabilidade foi medido semanalmente durante 15 meses, conforme mostram a Figura 3.14 e a Figura 3.15). 
Tabela 3.12 Composição química do lixiviado investigado por Francisca e Glatstein (2010).

\begin{tabular}{cc}
\hline Propriedade & Lixiviado \\
\hline $\mathrm{pH}$ & $5,2-8,1$ \\
Condutividade elétrica $(\mu \mathrm{S} / \mathrm{cm})$ & $21.136-68.742$ \\
Sólidos dissolvidos & $13.120-51.100$ \\
Cloreto $\left(\mathrm{Cl}^{-}\right)$ & $582-4.700$ \\
Sulfato $\left(\mathrm{SO}_{4}{ }^{-2}\right)$ & $80-2.000$ \\
Nitrato & $80-550$ \\
Sódio & $645-29.200$ \\
Potássio & $70-2.786$ \\
Cálcio & $42-2.880$ \\
Magnésio & $59-3.860$ \\
Fósforo Total $(\mathrm{P})$ & $5,20-23,50$ \\
Ferro Total & $28-126$ \\
Níquel & $0,03-2,1$ \\
Zinco & $1,0-13,5$ \\
Manganês & $15-96$ \\
Cromo & $0,14-2,20$ \\
Chumbo & $0,11-12,00$ \\
Cádmio & $0,11-0,62$ \\
DBO & $2.500-68.500$ \\
COD (carbono orgânico dissolvido) & $17.400-93.700$ \\
Nitrogênio amoniacal & $61-2.2250$ \\
Razão: DBO/COD & $0,14-0,73$ \\
Alcalinidade $($ CaCO & ) \\
Nitrogênio Kjeldahl total & $3.730-23.150$ \\
Valores em mg/L, exceto pH e condutividade elétrica
\end{tabular}

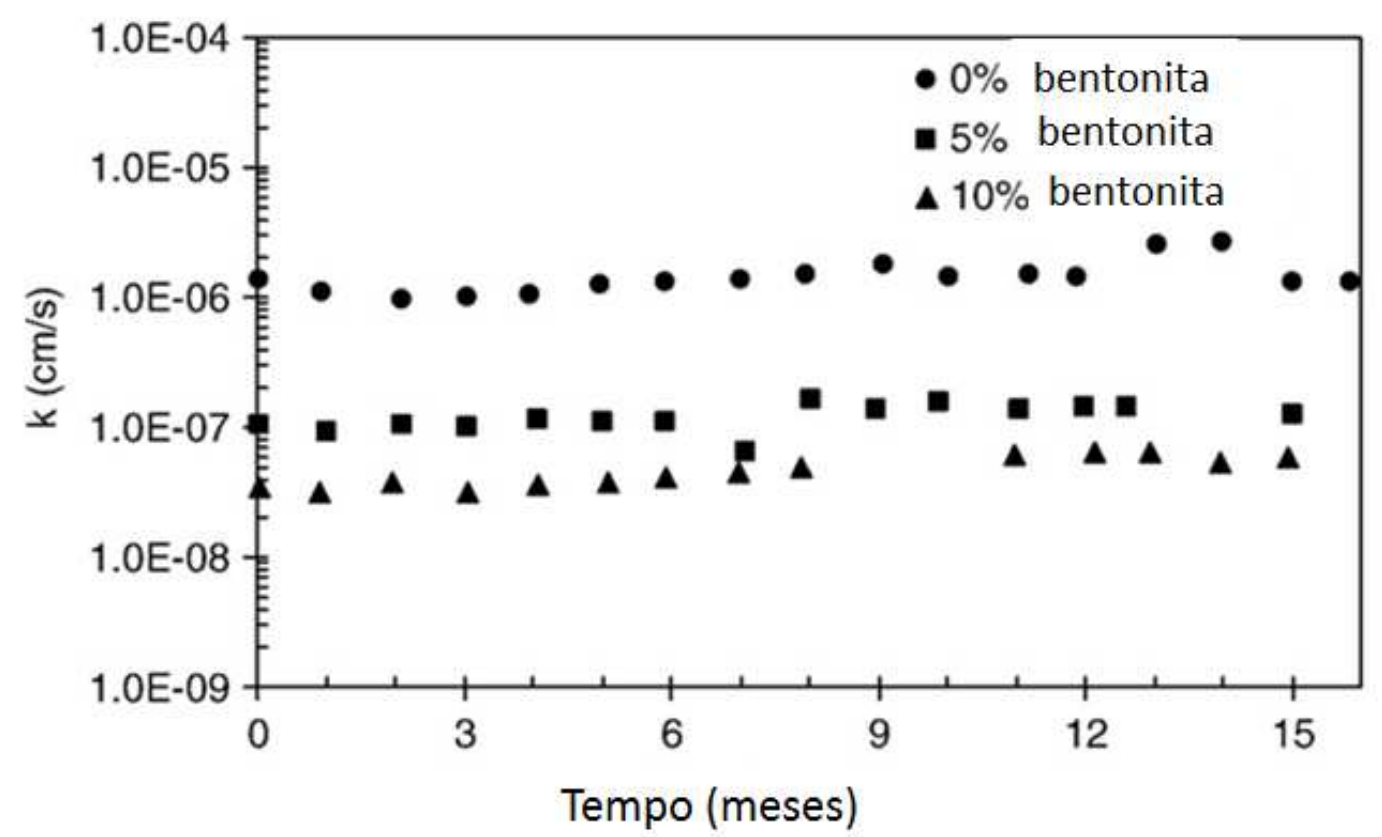

Figura 3.14 Coeficiente de permeabilidade $(\mathrm{cm} / \mathrm{s})$ de misturas de solo com bentonita percoladas com lixiviado (Francisca e Glatstein, 2010). 


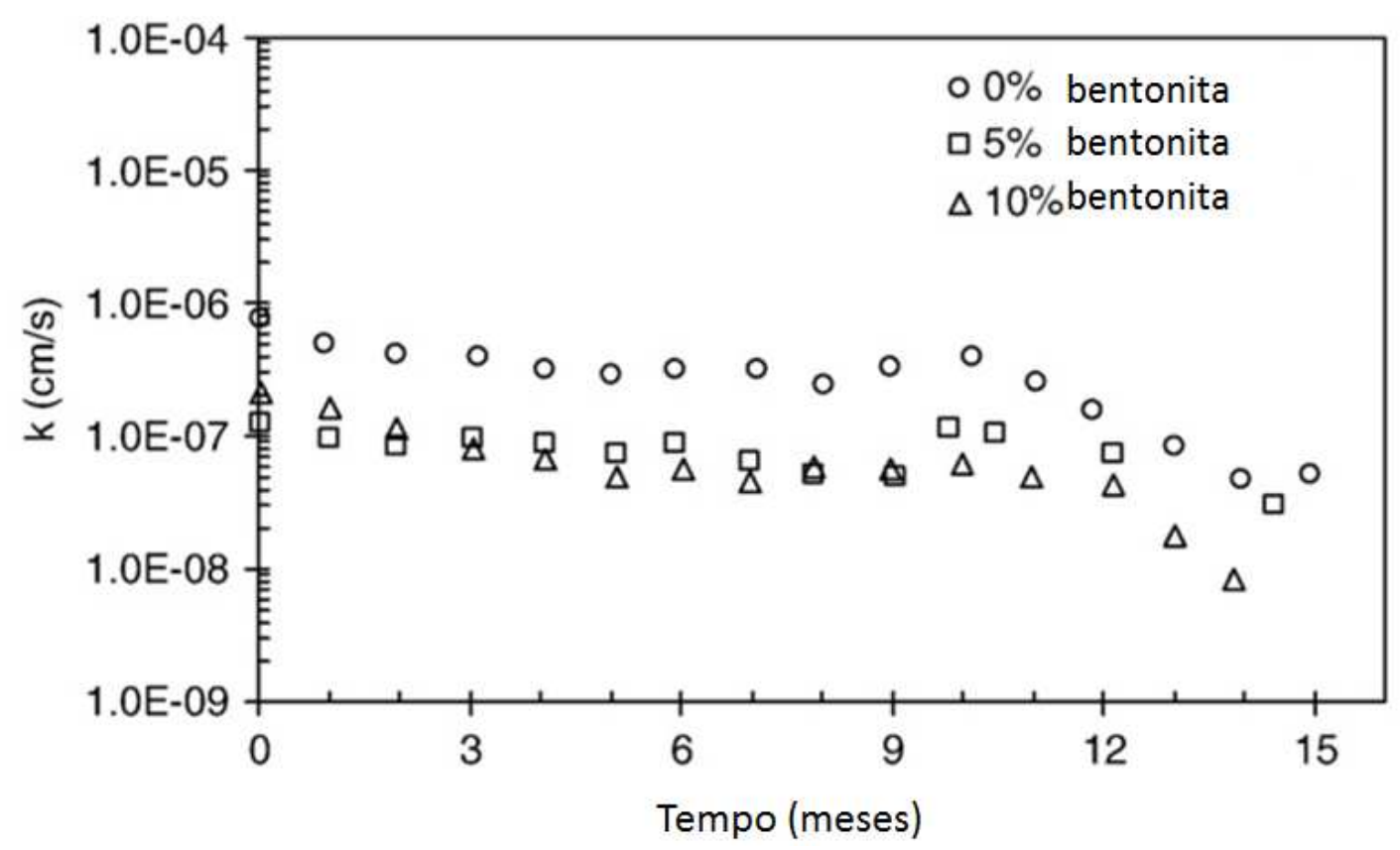

Figura 3.15 Coeficiente de permeabilidade $(\mathrm{cm} / \mathrm{s})$ de misturas de solo com bentonita percoladas com água destilada (Francisca e Glatstein (2010)

Para atingir o coeficiente de permeabilidade para o uso da mistura como impermeabilização de fundo de aterro sanitário $\left(10^{-9} \mathrm{~m} / \mathrm{s}\right)$, foi necessário mais de $5 \%$ de bentonita. Os autores observaram que não houve variação significativa do coeficiente de permeabilidade em relação ao tempo nos ensaios com percolação de água.

Frempong e Yanful (2008) estudaram três solos tropicais de Gana, denominados K, A e H, como base de aterro de RSU. O solo H é laterítico e os solos K e A, não lateríticos; pelo Sistema de Classificação Unificada de Solos (USCS), os três solos são considerados CH argila inorgânica de alta plasticidade. Foi avaliado o impacto causado pelo lixiviado de resíduos sólidos urbanos na mineralogia e na permeabilidade. Algumas características das argilas e do lixiviado utilizados estão apresentados na Tabela 3.13 e na Tabela 3.14.

Os resultados das alterações após a passagem do lixiviado foram: a superfície específica de cada solo diminuiu; a CTC aumentou; não houve mudanças significativas no LP; LL e IP foram reduzidos; e houve formação de novos minerais como hidroxiapatita, piromorfita, ferrihidrita, hidroxipiromorfita e estrengita. A permeabilidade, porém, não foi significativamente alterada $\left(9,5 \times 10^{-13}, 9 \times 10^{-11} \mathrm{~m} / \mathrm{s}\right.$ e $3,1 \times 10^{-11} \mathrm{~m} / \mathrm{s}$, respectivamente, para os solos K, A e H), sugerindo que os solos estudados são eficazes barreiras hidráulicas. 
Tabela 3.13 Características dos solos (Frempong e Yanful, 2008).

\begin{tabular}{cccc}
\hline Propriedade & Solo K & Solo A & Solo H \\
\hline Argila (\%) & 39 & 35 & 39 \\
Silte (\%) & 49 & 33 & 28 \\
Areia (\%) & 12 & 32 & 33 \\
Umidade ótima (\%) & 19 & 21,1 & 20,8 \\
Densidade seca máxima $\left(\mathrm{kN} / \mathrm{m}^{3}\right)$ & 16,32 & 15,7 & 15,92 \\
Limite de Liquidez & 87 & 54 & 56 \\
Índice de Plasticidade & 61 & 26 & 30 \\
Atividade & 1,54 & 0,77 & 0,55 \\
Índice de vazios & 0,80 & 0,81 & 0,77 \\
pH - solo:água - 1:1 & 6,9 & 4,9 & 4,7 \\
Coeficiente de permeabilidade do solo compactado $(\mathrm{m} / \mathrm{s})$ & $1,6 \times 10^{-12}$ & $7,8 \times 10^{-11}$ & $4,7 \times 10^{-11}$ \\
\hline
\end{tabular}

Tabela 3.14 Composição química do lixiviado (Frempong e Yanful, 2008).

\begin{tabular}{|c|c|}
\hline Propriedade & Lixiviado \\
\hline $\mathrm{pH}$ & 7,4 \\
\hline Condutividade elétrica a $25^{\circ} \mathrm{C}(\mu \mathrm{S} / \mathrm{cm})$ & 16.140 \\
\hline Sólidos suspensos & 2.330 \\
\hline Cloreto $\left(\mathrm{Cl}^{-}\right)$ & 1.781 \\
\hline Sulfato $\left(\mathrm{SO}_{4}{ }^{2-}\right)$ & 870 \\
\hline Brometo & 207 \\
\hline Fosfato & 47,4 \\
\hline Nitrato $\left(\mathrm{NO}_{3-} \mathrm{N}\right)$ & 2,51 \\
\hline Sódio & 1.415 \\
\hline Potássio & 1.100 \\
\hline Cálcio & 1.006 \\
\hline Magnésio & 401 \\
\hline Fósforo Total (P) & 8,51 \\
\hline Ferro Total & 5,89 \\
\hline Alumínio & 1,08 \\
\hline Níquel & 0,22 \\
\hline Zinco & 0,14 \\
\hline Chumbo & 0,05 \\
\hline Cobalto & 0,05 \\
\hline DBO & 131 \\
\hline COD (carbono orgânico dissolvido) & 1.802 \\
\hline Nitrogênio amoniacal & 1.164 \\
\hline Razão: DBO/COD & 0,07 \\
\hline COD/Nitrogênio amoniacal & 1,55 \\
\hline Alcalinidade $\left(\mathrm{CaCO}_{3}\right)$ & 5.744 \\
\hline Nitrogênio Kjeldahl total & 1.566 \\
\hline
\end{tabular}

Valores em $\mathrm{mg} / \mathrm{L}$, exceto $\mathrm{pH}$ e condutividade elétrica 
Para estudar a influência do lixiviado de aterros sanitários na expansão de solo, França et al. (2007) submeteram um GCL (composto impermeabilizante bentonítico) a hidratação com água de torneira, água destilada e lixiviado, sendo analisada também a situação com e sem sobrecarga de $5 \mathrm{kPa}$. A Figura 3.16 mostra que não há diferença significativa na expansão do GCL com água destilada ou de torneira, já com o lixiviado do Aterro Sanitário de São Carlos (SP) os valores de expansão atingem patamares menores, conforme se observa na Figura 3.17.

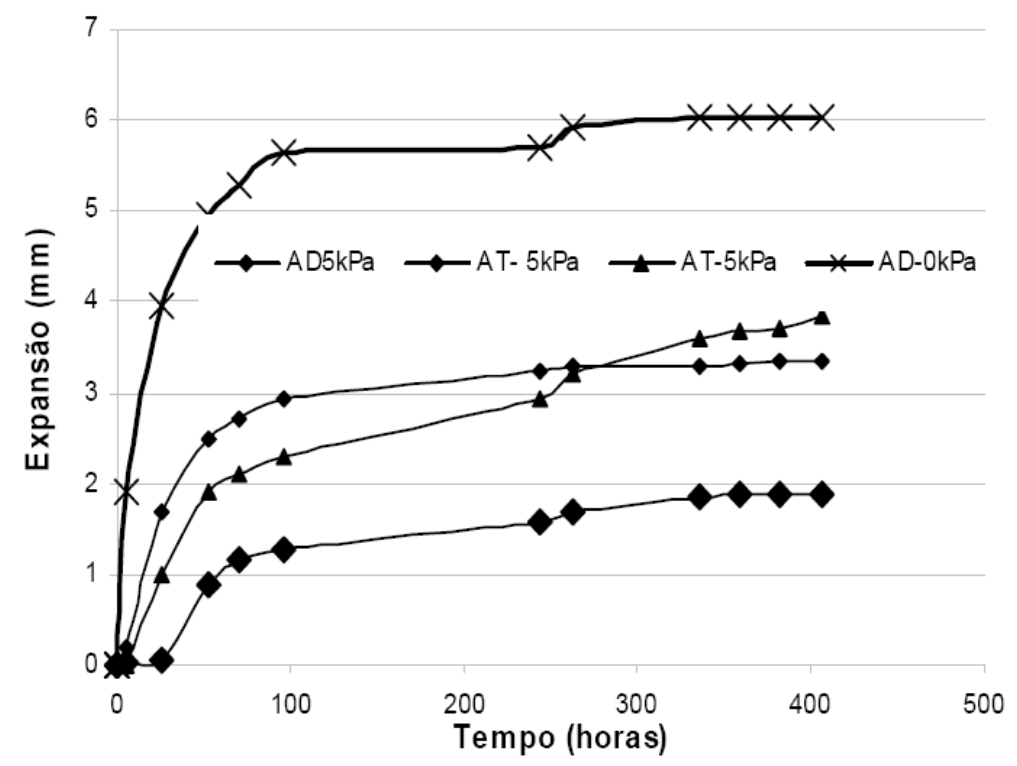

Figura 3.16 Expansão com água destilada (AD) e água de torneira (AT) (França et al., 2007).

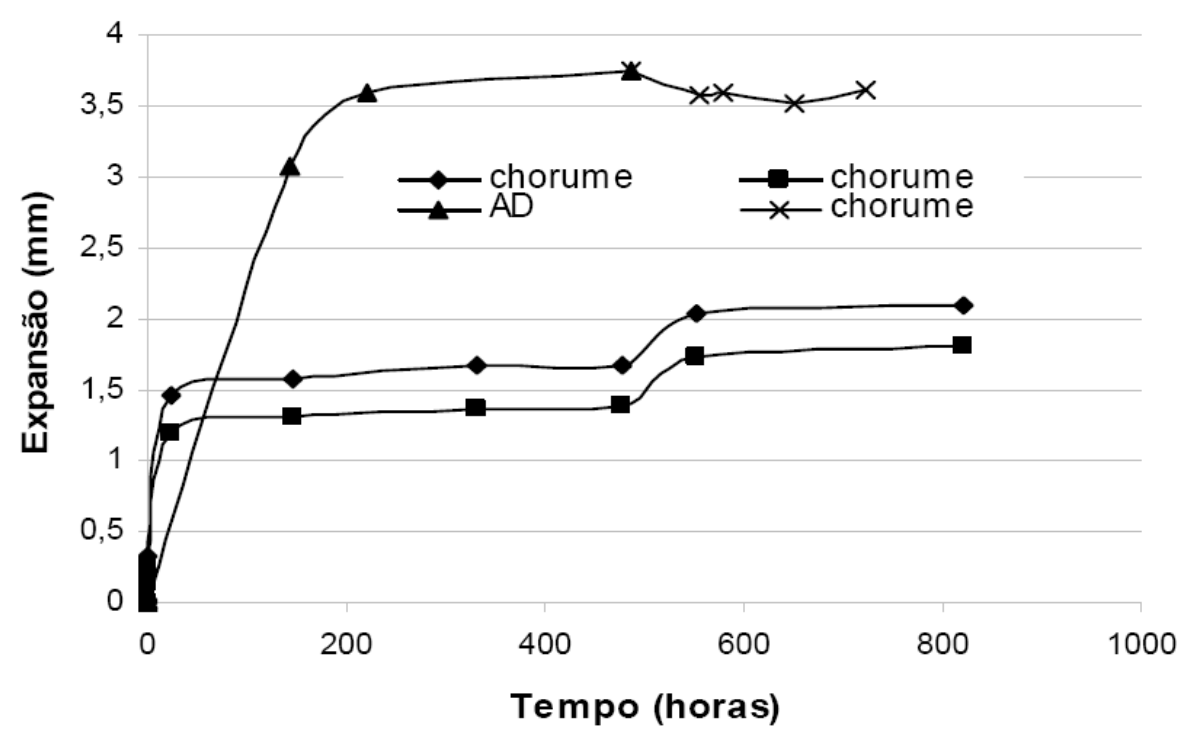

Figura 3.17 Expansão com lixiviado do Aterro Sanitário de São Carlos-SP (França et al., 2007). 


\section{INVESTIGAÇÃO EXPERIMENTAL}

\subsection{MATERIAIS}

\subsubsection{Solo}

O solo estudado é um silte saprolítico de filito, do município de Caieiras, na Região Metropolitana de São Paulo. Este solo foi objeto de estudo da dissertação de Ferrari (2005), quando foi iniciada a investigação sobre a utilização do solo local no revestimento de fundo do aterro sanitário da Central de Tratamento de Resíduos Caieiras (CTR-Caieiras), enfocando a permeabilidade da camada compactada. A localização da CTR-Caieiras está apresentada na Figura 4.1 .

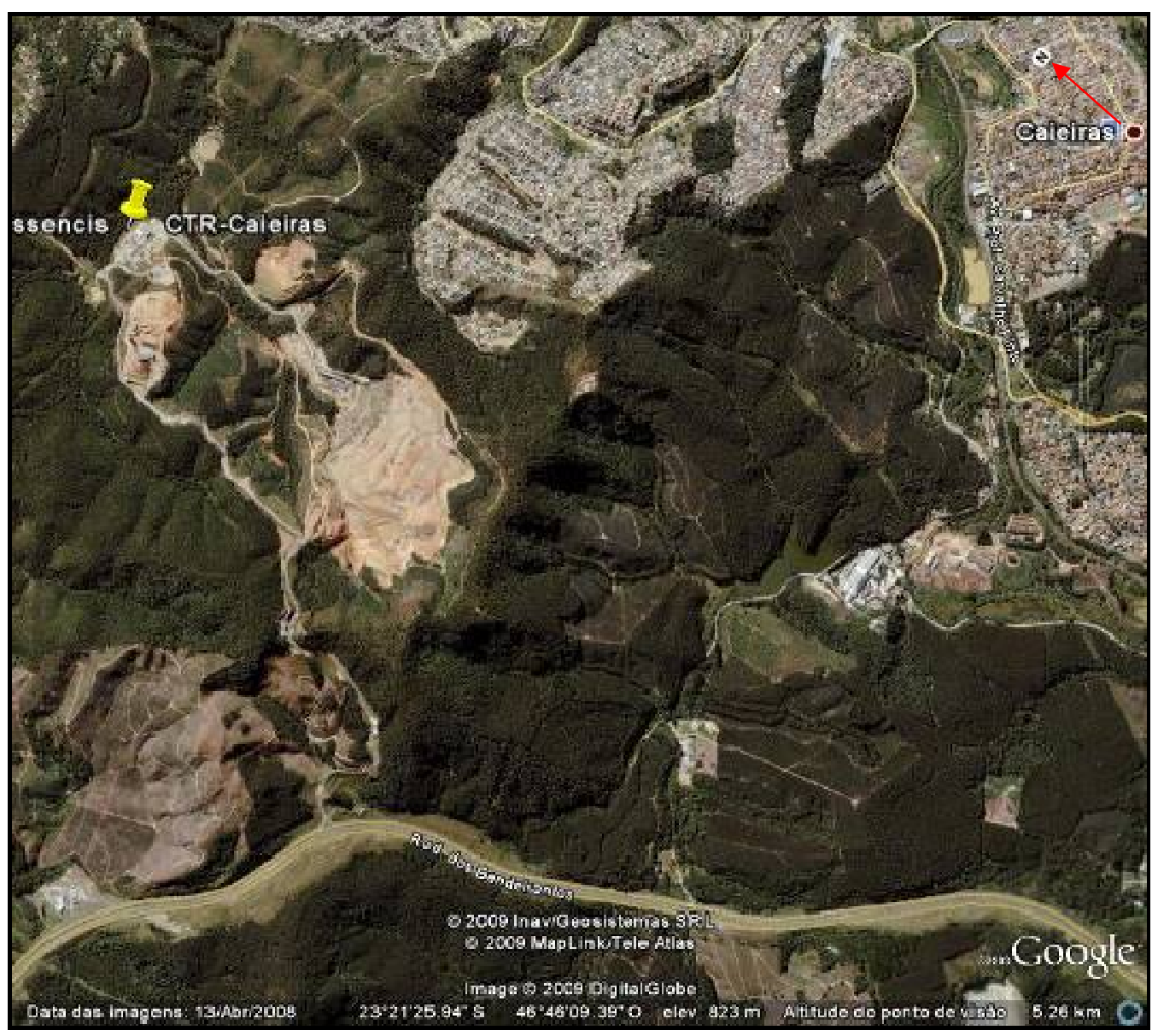

Figura 4.1 Vista superior do empreendimento (fonte: Google Earth em 09.10.2009, 14h). 
Sondagens na região da CTR-Caieiras mostraram a presença do silte saprolítico de filito em profundidades de até 70,0 m, não sendo encontrada a rocha sã. A camada do solo saprolítico é coberta por um solo residual maduro siltoso de espessura variável; em alguns locais, há uma camada de argila laterítica sobre o solo residual maduro. A Figura 4.2 mostra um perfil típico esquemático, e na Figura 4.3 está apresentado um talude de corte no solo saprolítico.

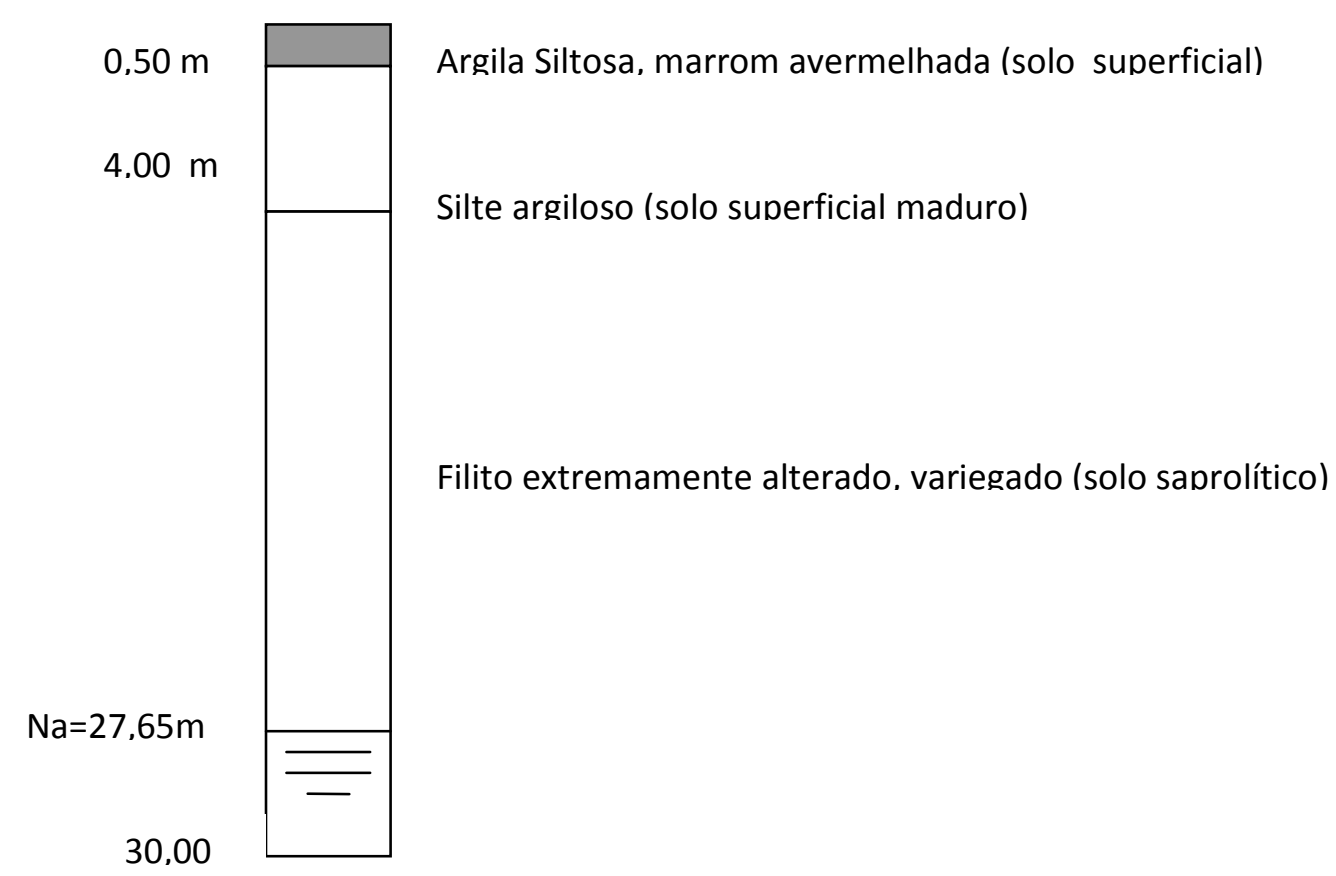

Figura 4.2 Perfil de sondagem típico da região da CTR-Caieiras (Ferrari, 2005).

No prosseguimento da pesquisa, complementando os ensaios de Ferrari, em dado momento foi necessário coletar mais material no campo. Os ensaios de laboratório foram realizados, portanto, com materiais de coletas executadas em datas distintas, porém localmente próximas. Denominou-se coleta 1 ao material coletado em 2004/2005 por Ferrari (2005) e coleta 2 ao material coletado em 2008. Ensaios de análise granulométrica, limites de Atterberg e compactação na energia modificada confirmaram a semelhança entre as amostras coletadas nas duas ocasiões (vide itens 5.1 a 5.6). Na Figura 4.4 vê-se o solo no campo no momento da coleta. 


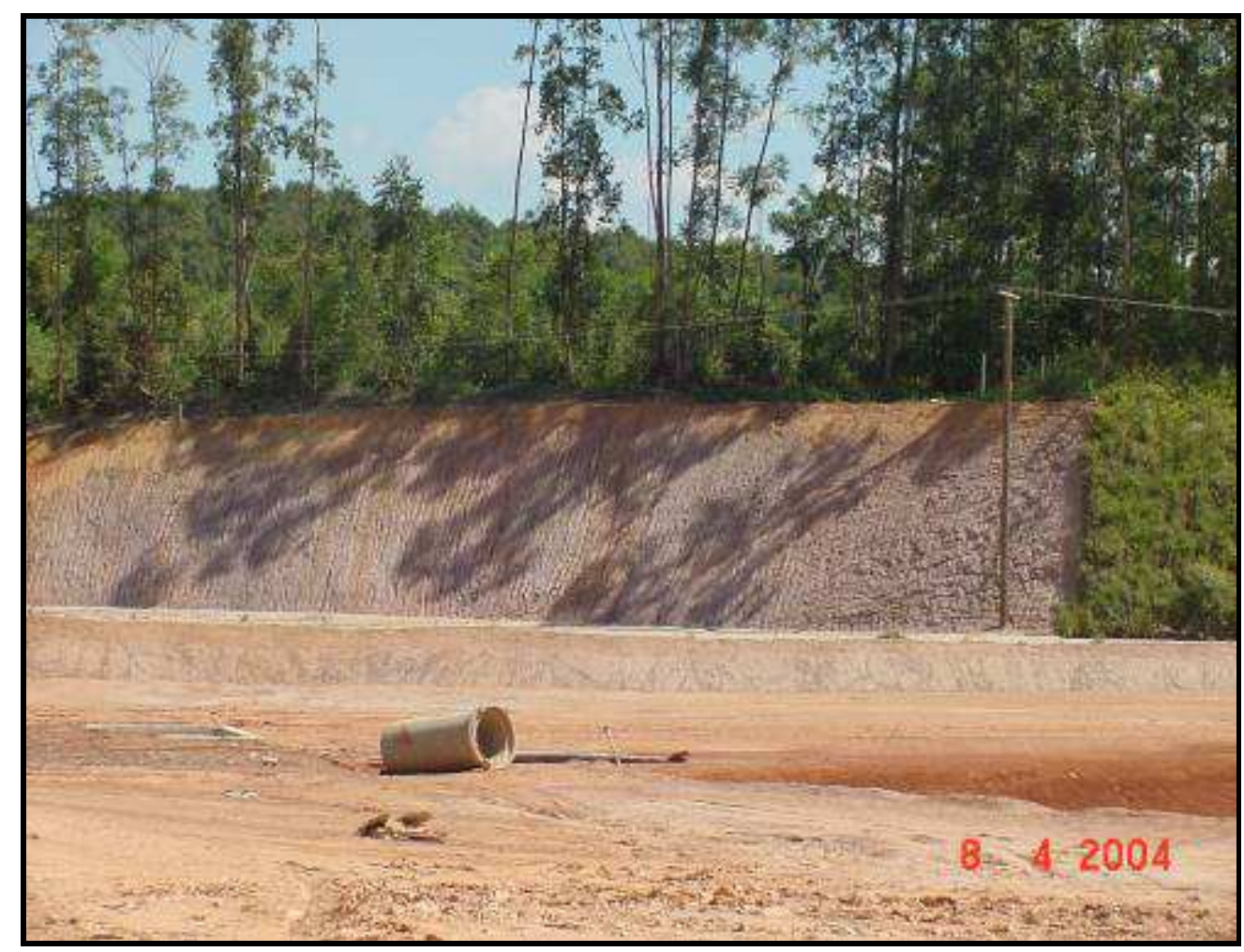

Figura 4.3 Talude de corte no solo saprolítico de filito da região da CTR-Caieiras (Ferrari, 2005).

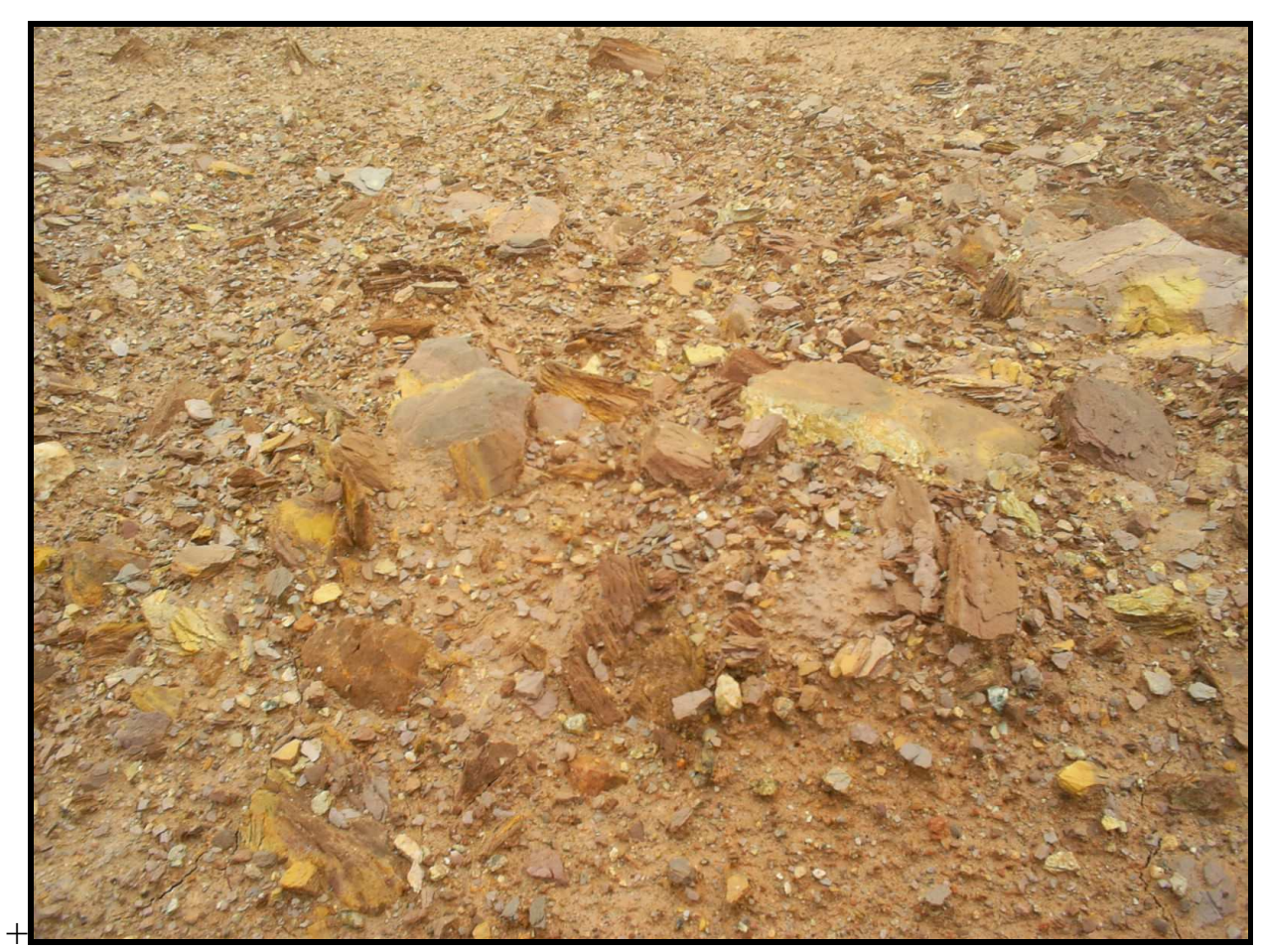

Figura 4.4 Detalhe do solo saprolítico no momento da coleta. 


\subsubsection{Bentonita}

A bentonita utilizada na investigação é conhecida como Permagel, produzida pela Bentonit União Nordeste Ind. e Com. Ltda., consistindo de uma mistura de bentonitas naturais com o objetivo de ser utilizada em aplicações geoambientais.

As características geotécnicas da bentonita Permagel estão apresentadas na Tabela 4.1.

Tabela 4.1 Características geotécnicas da bentonita (Convênio EPUSP/Bentonit, 2004).

\begin{tabular}{cc}
\hline Característica & Valor \\
\hline Peso específico dos grãos $\left(\mathrm{kN} / \mathrm{m}^{3}\right)$ & 28,3 a 30,5 \\
Porcentagem de argila $(\varnothing \leq 0,002 \mathrm{~mm})(\%)$ & 80 \\
Porcentagem de silte $(0,002 \mathrm{~mm}<\varnothing \leq 0,075 \mathrm{~mm})(\%)$ & 20 \\
Limite de Liquidez $(\%)$ & 540 \\
Limite de Plasticidade $(\%)$ & 60 \\
Umidade natural no LMS-EPUSP $(\%)$ & 17,2 \\
Umidade natural de fábrica $(\%)$ & 13,0 \\
Coeficiente de permeabilidade $(\mathrm{m} / \mathrm{s})$ & $10^{-12}-10^{-11}$
\end{tabular}

LMS-EPUSP = Laboratório de Mecânica dos Solos da Escola Politécnica da USP

\subsubsection{Misturas solo-bentonita}

Primeiramente o silte saprolítico foi destorroado manualmente e em seguida foi adicionada bentonita. As misturas foram realizadas a seco, com o solo e a bentonita na umidade higroscópica, até que o material atingisse uma aparência homogênea.

A seguir foi realizado o acerto de umidade e homogeneização da mistura, a qual era deixada em repouso em um saco plástico fechado por no mínimo 24 horas; só então iniciava a fase de compactação.

Este procedimento foi o que melhor garantiu a homogeneização da mistura, ao contrário das observações de Tripathi e Viswanadahm (2005), segundo os quais a distribuição de bentonita é melhor para maiores teores de umidade nas misturas areia-bentonita e não há efeito significativo do teor de umidade para misturas argila-bentonita (vide item 3.4). 


\subsubsection{Lixiviado}

O lixiviado utilizado foi proveniente da Central de Tratamento de Resíduos Caieiras, coletado na saída do tubo coletor do sistema de drenagem no tanque de lixiviado, conforme se observa na Figura 4.5. Foi acondicionado em recipiente plástico, transportado até o Laboratório de Mecânica dos Solos da EPUSP, sendo armazenado em geladeira a fim de preservar suas características físico-químicas. Como em Francisca e Glatstein (2010), antes da realização dos ensaios, o lixiviado foi filtrado em papel-filtro para a remoção de partículas sólidas.

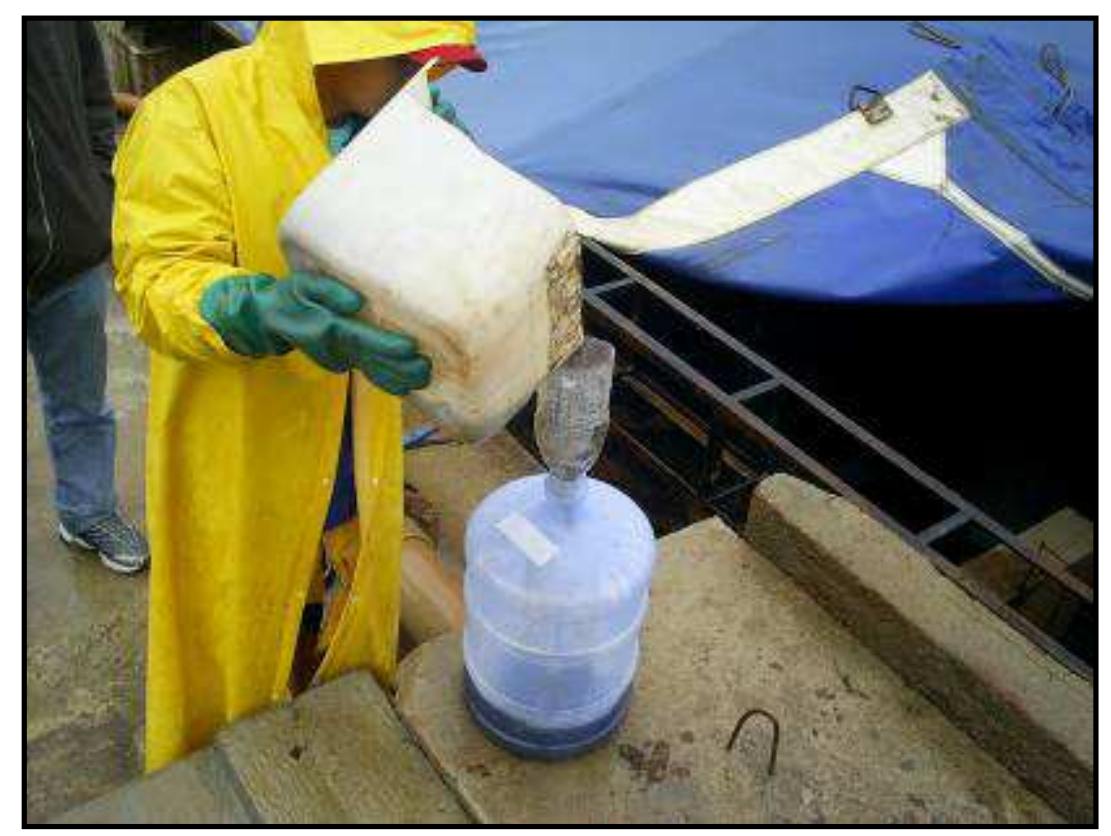

Figura 4.5 Coleta do lixiviado. 


\subsection{ENSAIOS REALIZADOS}

\subsubsection{Granulometria}

A curva de distribuição granulométrica do solo saprolítico de filito foi obtida segundo a NBR 7181 (ABNT, 1984).

\subsubsection{Densidade dos grãos}

Foi determinada a densidade dos grãos segundo a NBR 6508 (ABNT, 1984) para o solo natural e as misturas com $5 \%$ e $10 \%$ de bentonita.

\subsubsection{Limites de Atterberg}

Os limites de liquidez e plasticidade foram determinados segundo a NBR 6459 (ABNT, 1984) e NBR 7180 (ABNT, 1988) para o solo natural e as misturas com 5\% e 10\% de bentonita.

\subsubsection{Caracterização mineralógica}

A composição mineralógica do solo foi determinada por meio de ensaios de difração de raios $\mathrm{X}$ (DRX), microscopia eletrônica de varredura com elétrons secundários (MEV-SE) e microscopia eletrônica de varredura tipo BSE (MEV-BSE) associada a microanálise química com EDS, realizados no Laboratório de Caracterização Tecnológica da Escola Politécnica da USP. A difração foi realizada em equipamento X' PERT com tubo de cobre $45 \mathrm{KV}$ e $40 \mathrm{~mA}$, com varredura contínua, ângulo inicial de $4^{\circ}$, ângulo final de $70^{\circ}$, tamanho do passo $0,02^{\circ} \mathrm{e}$ tempo de 20s. A identificação das fases cristalinas foi obtida por comparação do difratograma da amostra com os bancos de dados PDF2 do ICDD - International Centre for Diffraction Data (2003) e PAN-ICSD - PANalytical Inorganic Crystal Structure Database (2007).

Para os ensaios de MEV-BSE, a amostra foi recoberta de C (carbono) e para os ensaios de MEV-SE, a amostra foi recoberta com Au (ouro), que servem para conduzir os feixes de elétrons que incidem sobre a amostra durante a realização dos ensaios, no interior da câmara de vácuo do microscópio. Salienta-se que no MEV-BSE é possível identificar algumas fases 
minerais com o uso do detector de EDS, já no MEV-SE observam-se imagens da amostra com foco em sua morfologia, forma e tamanhos dos grãos.

\subsubsection{Caracterização química do solo}

A composição química do solo foi determinada por meio de análise semiquantitativa sem padrões ("standarless") com análise de elementos químicos de flúor a urânio, em espectrômetro por fluorescência de raios X Axios Advanced, marca PANalytical, e perda ao fogo efetuada a $1050^{\circ} \mathrm{C}$ por 1 hora, no Laboratório de Caracterização Tecnológica da Escola Politécnica da USP.

A capacidade de troca catiônica, o teor de matéria orgânica e o pH do solo foram determinados no Departamento de Ciência do Solo da Escola Superior de Agricultura Luiz de Queiroz da USP segundo os métodos preconizados pela EMBRAPA (1997 e 1999) e Raij et al. (2001).

\subsubsection{Compactação}

Ferrari (2005) realizou ensaios de compactação na energia normal com o solo natural e na energia modificada com o solo natural e com misturas contendo $5 \%$ e $10 \%$ de bentonita. Determinando a permeabilidade desses materiais, constatou que uma mistura com 5\% de bentonita compactada na energia modificada apresenta permeabilidade menor do que o limite máximo aceitável para revestimentos impermeabilizantes ("liners”) de aterros de resíduos.

Procurou-se nesta pesquisa verificar se uma mistura com 5\% de bentonita compactada na energia normal também atenderia ao limite de permeabilidade. Para tal, foi realizado um ensaio de compactação de uma mistura de solo contendo $5 \%$ de bentonita em peso seco na energia normal, seguindo os procedimentos descritos na norma NBR 7182 (1988). Refez-se também o ensaio de compactação na energia modificada com o solo natural da coleta 2, para verificar sua semelhança com o solo da coleta 1 . 


\subsubsection{Densidade do lixiviado}

Foi realizado também o estudo de densidade do lixiviado, já que esta tem influência direta na permeabilidade (Lambe e Whitman, 1969), assim como a viscosidade.

\subsubsection{Permeabilidade de carga constante}

A programação dos ensaios de permeabilidade visou a complementar a investigação de Ferrari (2005), de modo a se obter o coeficiente de permeabilidade do solo e de misturas de solo e bentonita com teores de 2,5\%, 5\%, 7,5\% e 10\% em peso seco, com compactação nas energias normal e modificada. Para o solo natural compactado na energia normal programouse determinar a permeabilidade no ramo seco e no ramo úmido. Para os demais ensaios, o material foi compactado no ramo úmido, que é a especificação usual para revestimentos impermeabilizantes de aterros de resíduos (Daniel, 1984).

O aparelho utilizado foi o Tri-Flex 2 da ELE International Inc./ Soiltest Products Division, que é um permeâmetro de carga constante e parede flexível. A tensão confinante aplicada foi de $50 \mathrm{kPa}$ e o gradiente hidráulico de 30, conforme recomendação da norma D5084 - 03 (ASTM 2003). Salienta-se que em aterros sanitários os gradientes hidráulicos são menores, portanto esperam-se menores velocidades de fluxo, favorecendo as reações de adsorção específica que dependem do tempo de contato em solo e poluente.

Os ensaios de permeabilidade foram realizados em ambiente com temperatura controlada a $(20 \pm 3)^{\circ} \mathrm{C}$.

O material era inicialmente compactado no cilindro de Proctor, com a energia, o teor de umidade e teor de bentonita desejados. Após a extrusão, os corpos-de-prova eram talhados em forma cilíndrica com aproximadamente $0,07 \mathrm{~m}$ de diâmetro e 0,05 $\mathrm{m}$ de altura.

O solo era envolto em membrana de borracha impermeável e flexível, colocado no permeâmetro juntamente com a pedra porosa e o papel filtro, instalados no topo e na base do corpo-de-prova; em seguida era instalado o cabeçote superior. O permeâmetro era então preenchido por água e aplicava-se uma tensão confinante com as drenagens de topo e base abertas. Após a fase de adensamento, aplicava-se uma tensão de percolação na base do corpo- 
de-prova, estando o topo à pressão atmosférica; o fluxo ascendente foi escolhido para facilitar a expulsão do ar contido nos vazios do corpo-de-prova.

Os volumes de água que entravam pela base e saíam pelo topo do corpo-de-prova eram medidos através de buretas graduadas.

A Figura 4.6 mostra o ensaio de permeabilidade em andamento.

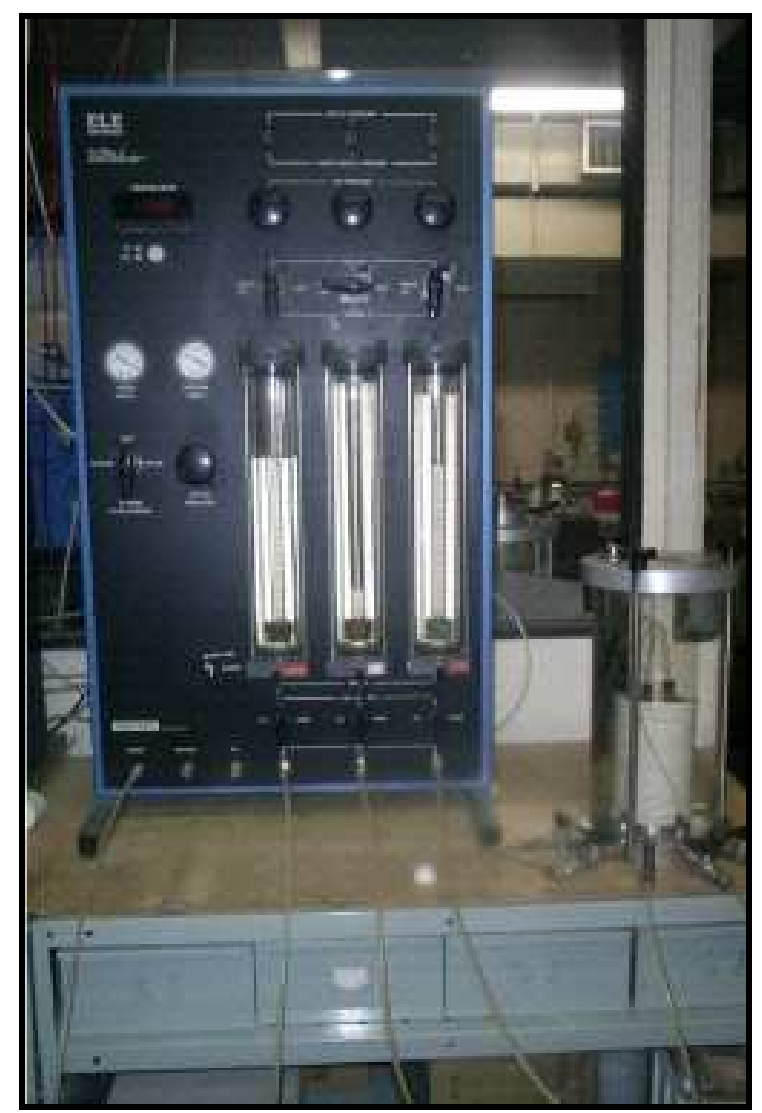

Figura 4.6 Ensaio de permeabilidade no aparelho Tri-Flex 2.

O ensaio era encerrado após a passagem de cerca de duas vezes o volume de vazios, verificando-se se havia sido atingida a constância do coeficiente de permeabilidade na base e no topo do corpo-de-prova.

As medidas de dimensão, umidade e peso do corpo de prova eram determinadas no início e final dos ensaios. 
Foram realizados, ainda, ensaios de permeabilidade do solo natural e da mistura de solo com $5 \%$ de bentonita, com a percolação de lixiviado. O ensaio começou como um ensaio de permeabilidade à água; as fases de adensamento e percolação foram realizadas conforme descrito anteriormente, até se atingir a constância do coeficiente de permeabilidade na base e no topo do corpo-de-prova. Então se modificou a instalação: o fluxo de água passou a ser descendente e a fonte de água do aparelho Tri-Flex 2 foi substituída por um frasco de Mariotte instalado de modo a se obter um gradiente hidráulico de aproximadamente 30 (Figura 4.7). O volume de água pelo corpo-de-prova passou a ser medido na base do corpode-prova, em uma bureta graduada à pressão atmosférica.

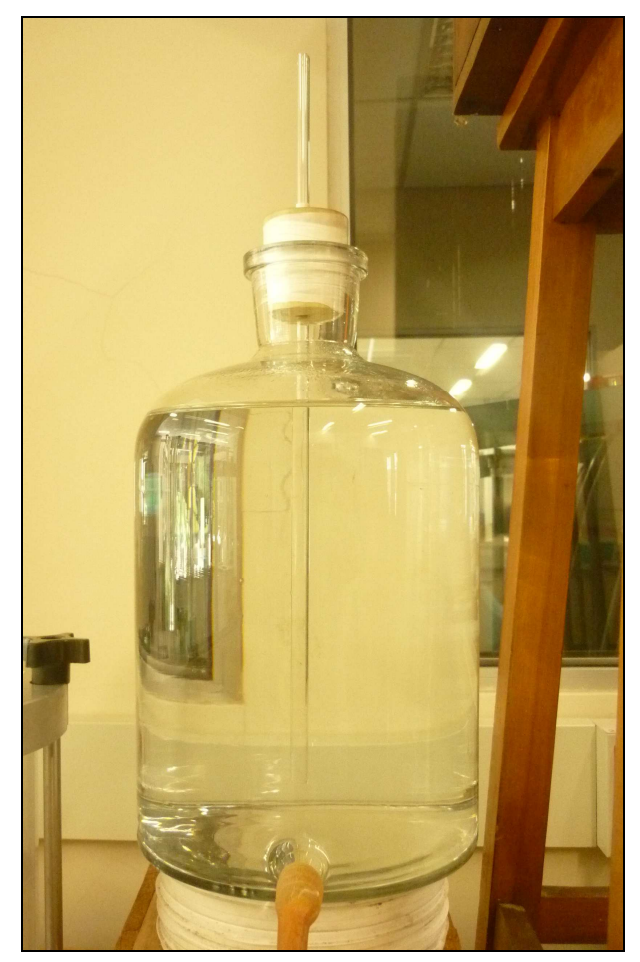

Figura 4.7 Frasco de Mariotte contendo água

Após se atingir novamente constância do coeficiente de permeabilidade, trocou-se o líquido do frasco de Mariotte pelo lixiviado, com o objetivo de acompanhar a variação no coeficiente de permeabilidade devido a sua percolação pelo corpo-de-prova, ou seja, verificar a compatibilidade entre o solo e o lixiviado. A etapa intermediária do ensaio teve o objetivo de verificar alterações na permeabilidade devidas à modificação do gradiente hidráulico e do sentido do fluxo. 


\subsubsection{Adensamento edométrico}

O ensaio de adensamento foi realizado segundo a NBR 12007 (ABNT, 1990), com o solo saprolítico e uma mistura contendo $5 \%$ de bentonita em peso seco, compactados no ramo úmido da energia modificada. Os líquidos utilizados para a inundação do corpo-de-prova foram água e lixiviado. É importante salientar que, no ensaio com lixiviado, foi utilizada uma célula de adensamento de aço inox, especialmente fabricada para esta pesquisa, bem como que houve cuidados para proteger a integridade do aparelho de adensamento, cobrindo todas as partes expostas com filme plástico e papel toalha.

O material era inicialmente compactado no cilindro de Proctor. Após a extrusão do cilindro, os corpos-de-prova eram talhados com área de seção transversal circular de diâmetro de $0,07 \mathrm{~m}$ e altura de $0,02 \mathrm{~m}$. A moldagem do corpo-de-prova, para que o solo ficasse bem ajustado no anel de adensament,o era realizada utilizando-se o anel como um molde: à medida que o solo ia sendo desbastado nas dimensões desejadas, o anel ia sendo empurrado para baixo e cravado no material. Na Figura 4.8 pode-se observar o corpo-de-prova sendo desbastado sob o anel de adensamento.

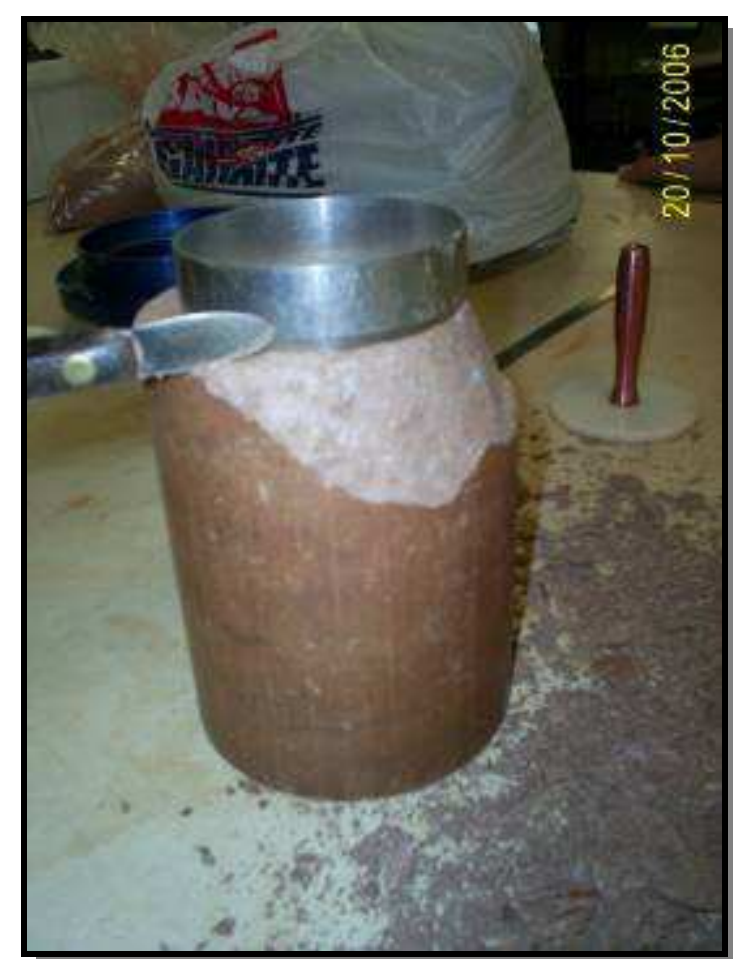

Figura 4.8 Desbastamento do corpo-de-prova para moldagem no anel de adensamento. 
Em seguida o solo era colocado na célula de adensamento, com uma pedra porosa e um papel filtro no topo e na base do corpo-de-prova. Na Figura 4.9 pode-se ver a preparação da célula de adensamento no momento da colocação do conjunto pedra porosa, papel filtro e cabeçote metálico no topo do corpo-de-prova. A partir daí o conjunto era levado para o equipamento de adensamento e inundado; em seguida iniciava-se a aplicação das pressões, conforme apresentado na Figura 4.10.

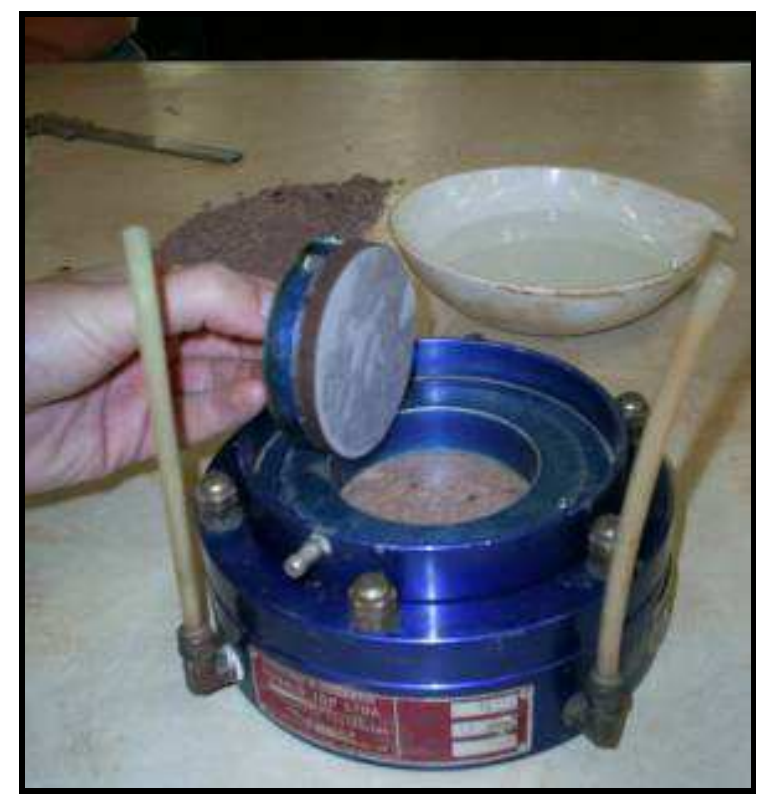

Figura 4.9 Foto da montagem da célula de adensamento.

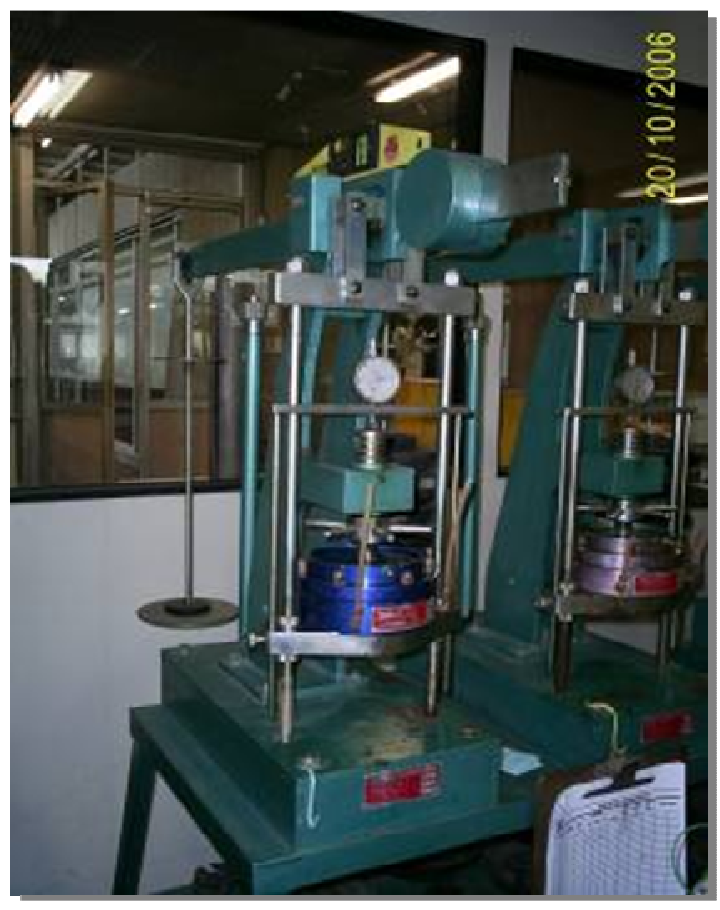

Figura 4.10 Ensaio de adensamento. 


\subsubsection{Cisalhamento direto}

Foram realizados ensaios de cisalhamento com amostras de solo e com misturas de solo e bentonita com teor de $5 \%$ em peso seco, compactadas na energia modificada, no ramo úmido. Ainda, utilizaram-se água e lixiviado como líquidos de inundação. Os ensaios realizados com lixiviado contaram com uma caixa de cisalhamento de inox, especialmente fabricada para esta pesquisa; além disso, houve cuidados para proteger a integridade do aparelho de cisalhamento, cobrindo todas as partes expostas com filme plástico e papel toalha.

O material era inicialmente compactado no cilindro de Proctor. Após a extrusão do cilindro, os corpos-de-prova eram talhados com área de seção transversal quadrada de $36 \times 10^{-4} \mathrm{~m}^{2}(36$ $\mathrm{cm}^{2}$ ) e altura de $0,025 \mathrm{~m}$. A moldagem era realizada de forma análoga à do ensaio de adensamento.

Na preparação da caixa de cisalhamento, foi colocado no topo e na base do corpo-de-prova um conjunto de placa ranhurada com furos, papel filtro e pedra porosa. A Figura 4.11 mostra a instalação do conjunto de placa ranhurada com furos, papel filtro e pedra porosa sobre o topo do corpo-de-prova. Ao lado vê-se o cabeçote da caixa de cisalhamento que será em seguida colocado sobre o conjunto.

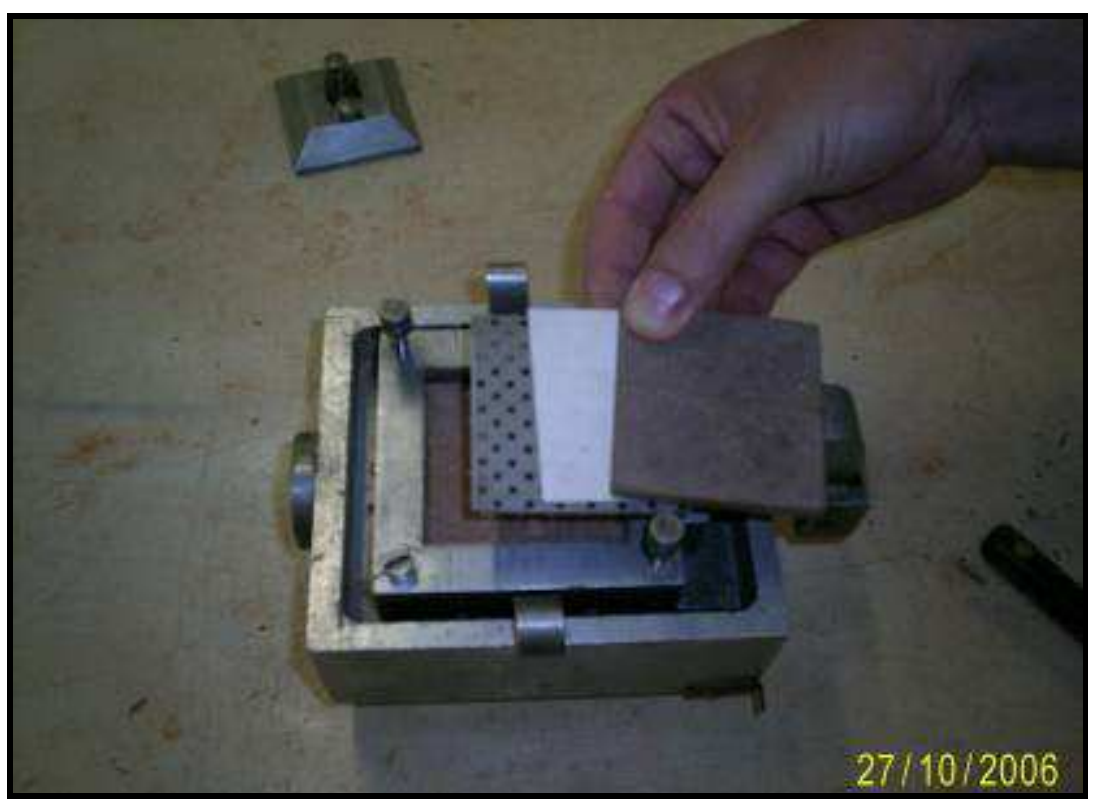

Figura 4.11 Montagem do material na caixa de cisalhamento direto. 
A caixa era então posicionada no aparelho de cisalhamento e em seguida aplicada uma tensão vertical. O aparelho utilizado foi o Wykeham - Ferrance. A fase de adensamento sob a tensão vertical durava $24 \mathrm{hs}$. $\mathrm{O}$ cisalhamento foi realizado em $1 \mathrm{~h}$, com velocidade de $0,13 \mathrm{~mm} / \mathrm{min}$. A Figura 4.12 mostra a fase de cisalhamento sendo iniciada. A caixa está posicionada no aparelho, a tensão vertical está aplicada no topo do corpo-de-prova e está-se adicionando água para inundar o corpo-de-prova.

As tensões verticais utilizadas foram $50 \mathrm{kPa}, 100 \mathrm{kPa}$ e $200 \mathrm{kPa}$, adotadas considerando um aterro de resíduos sólidos urbanos com peso específico de $10 \mathrm{kN} / \mathrm{m}^{3}$ (valor típico de RSU brasileiros compactados e degradados, com base em Marques (2001), Silveira (2004) e Boscov (2008), e espessura de aproximadamente $20 \mathrm{~m}$.

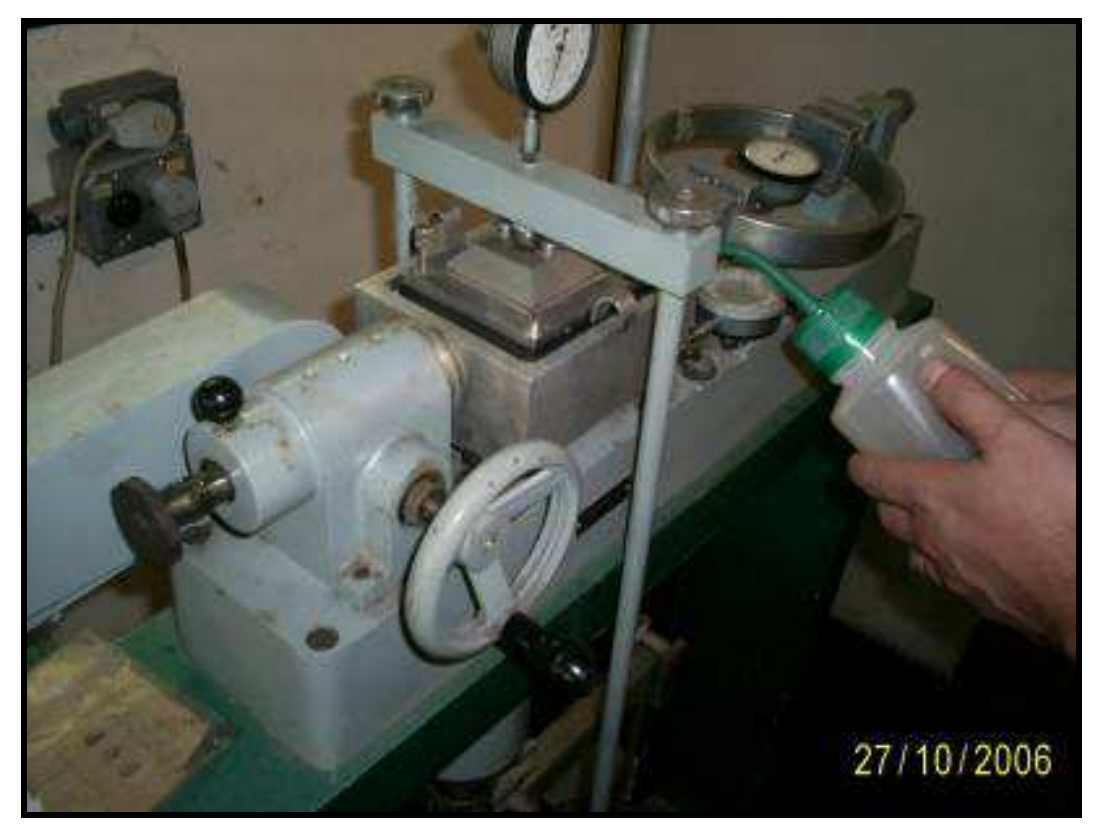

Figura 4.12 Foto do andamento do ensaio de cisalhamento direto.

\subsubsection{Expansão}

As tensões aplicadas no solo após a construção do aterro sanitário são elevadas, portanto a presença de materiais expansivos não é problemática quando o maciço tem altura elevada. Porém, durante a implantação e operação do aterro, a expansão do solo pode comprometer a integridade do revestimento de fundo e danificar os drenos de lixiviado. Decidiu-se realizar ensaios de expansão tendo em vista que o solo é expansivo e que a bentonita Permagel é extremamente expansiva. 
Os ensaios de expansão foram realizados com amostras de solo e com misturas de solo e bentonita com teor de $5 \%$ em peso seco, compactadas na energia modificada, no ramo úmido, utilizando-se como líquidos de inundação água e lixiviado.

A montagem do ensaio de expansão foi realizada de forma análoga à descrita no ensaio de adensamento. Após colocar a célula de adensamento na prensa, inicia-se a inundação. A partir daí, procura-se impedir a expansão com a aplicação de cargas verticais, conforme apresentado por Stuermer (2006). A pressão de expansão é dada pela soma das cargas aplicadas para manter nula a deformação vertical. Quando as deformações se estabilizam, retira-se de uma vez a carga total aplicada e deixa-se o corpo-de-prova expandir livremente. Stuermer (2006) concluiu após comparar dois diferentes processos de determinação da pressão de expansão que este é o de mais simples execução.

Na Figura 3.16 podem-se observar alguns cuidados tomados na hora de executar o ensaio com o lixiviado:

- A célula utilizada no ensaio foi especialmente fabricada em aço inox, para evitar sua corrosão;

- Para evitar que o lixiviado entrasse em contato com a prensa, o que poderia deteriorála, foi utilizado papel toalha e filme plástico; e

- Buscou-se cobrir o recipiente do lixiviado, evitando que houvesse propagação dos agentes biológicos nele existentes. 


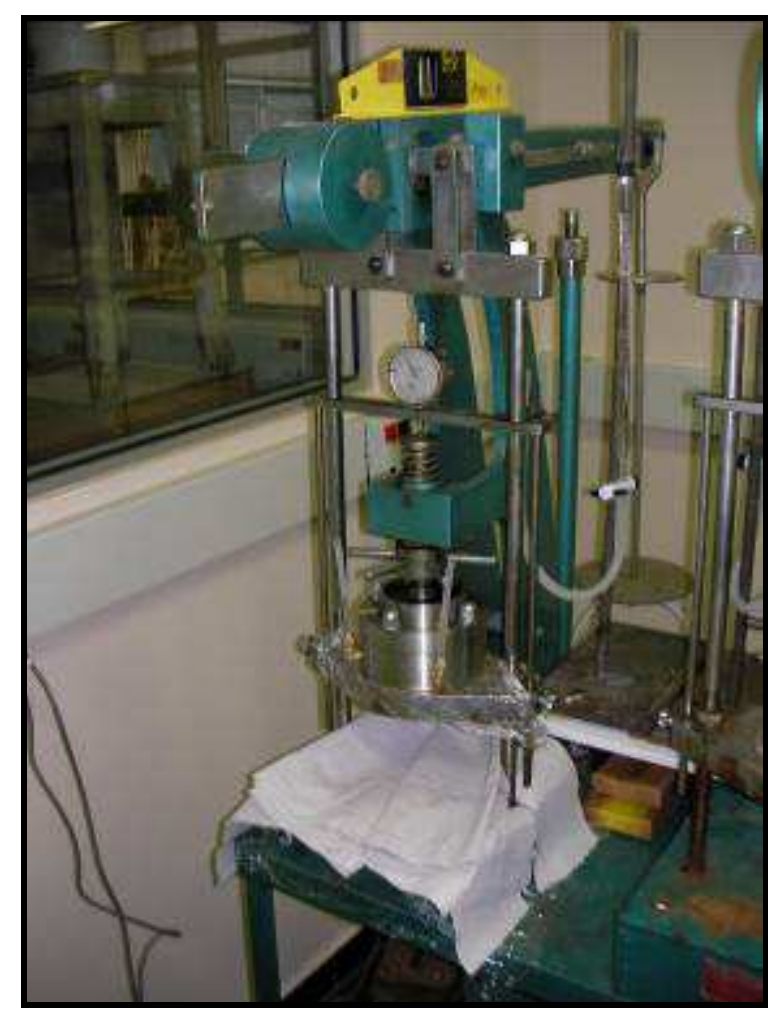

(a)

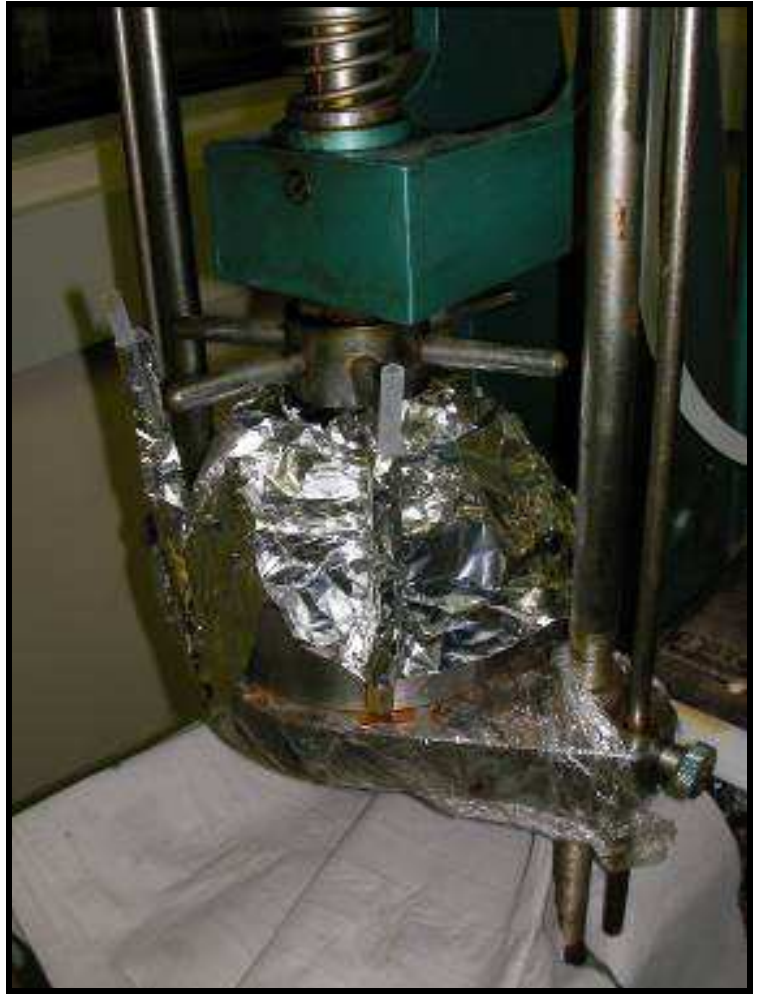

(b)

Figura 4.13 Ensaio de expansão com lixiviado: (a) vista geral da montagem do ensaio; (b) detalhe da célula de expansão com utilização de papel toalha e filme plástico. 


\section{RESULTADOS}

\subsection{GRANULOMETRIA}

A Figura 5.1 mostra a curva de distribuição granulométrica do solo saprolítico de filito obtida com as amostras das coletas 1 e 2 .

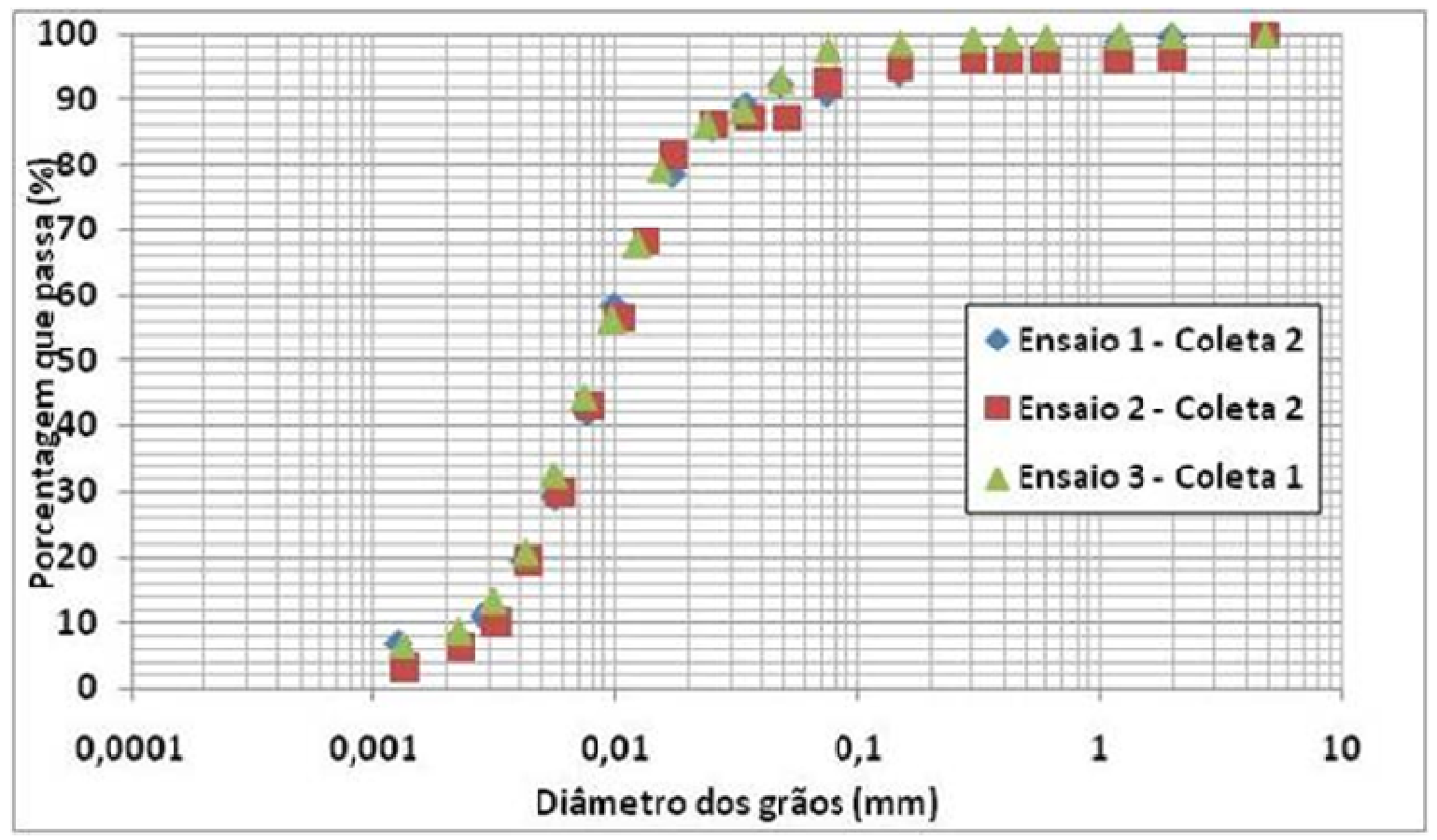

Figura 5.1 - Distribuição granulométrica do solo saprolítico de filito - coletas 1 e 2.

Das curvas de distribuição granulométrica da Figura 5.1 pode-se observar que as amostras da Coleta 1 e Coleta 2 são realmente do mesmo solo, que é um silte arenoso.

\subsection{DENSIDADE DOS GRÃOS}

Os resultados dos ensaios de densidade dos grãos estão apresentados na Tabela 5.1. Para o solo natural, a densidade dos grãos está próxima dos valores obtidos por Cruz (1996), entre $27,6 \mathrm{kN} / \mathrm{m}^{2}$ a $28,1 \mathrm{kN} / \mathrm{m}^{3}$, para amostras de silte saprolítico de filito do Estado de São Paulo. 
Tabela 5.1 Densidade dos grãos.

\begin{tabular}{lc}
\hline Material & Valor $\left(\mathbf{k N} / \mathbf{m}^{3}\right)$ \\
\hline Coleta 1 - solo natural & 27,75 \\
Coleta 2 - solo natural & 27,46 \\
Coleta 2 - mistura com 5\% de bentonita & 27,65 \\
Coleta 2 - mistura com 10\% de bentonita & 27,84 \\
\hline
\end{tabular}

Do que se pode observar dos valores da Tabela 5.1 e da Tabela 4.1, o peso específico dos grãos da bentonita utilizada no ensaio é da ordem de $30,5 \mathrm{kN} / \mathrm{m}^{3}$.

\subsection{LIMITES DE ATTERBERG}

Para o solo natural e para as misturas com $5 \%$ e $10 \%$ de bentonita, os resultados estão apresentados na Tabela 5.2 e na Figura 5.2, onde estão comparados com os limites de Atterberg de solos saprolíticos obtidos por Mori (1987) (Figura 3.3).

Tabela 5.2 Limites de Atterberg

\begin{tabular}{ccccc}
\cline { 2 - 5 } & LL & LP & IP & USCS \\
\hline Solo natural - Coleta 1 & 41 & 30 & 11 & ML \\
Solo natural - Coleta 2 & 35 & 28 & 7 & ML \\
Solo + 5\% bentonita - Coleta 2 & 41 & 33 & 8 & ML \\
Solo + 10\% bentonita - Coleta 2 & 52 & 36 & 15 & MH \\
\hline
\end{tabular}

Pela Classificação USCS, o solo é ML, ou silte de baixa plasticidade. O acréscimo de bentonita elevou os limites de Atterberg, mas mais significativamente o LL do que o LP, resultando em um aumento do IP. Para $10 \%$ de bentonita, o material passa a ser um silte de alta plasticidade. 


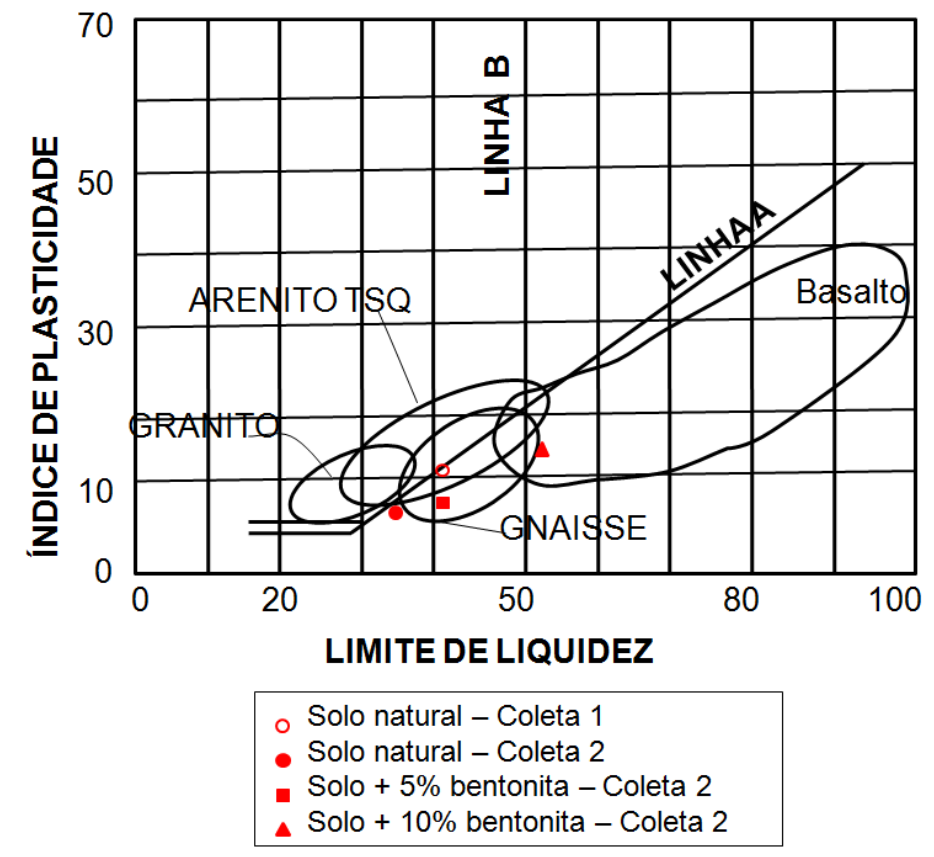

Figura 5.2 Limites de Atterberg dos materiais estudados.

Os valores de limites de Atterberg obtidos neste estudo estão dentro da faixa de valores encontrados para solos residuais de filito do Estado de São Paulo apresentados por Cruz (1996), conforme se observa na Tabela 5.3, apesar de algumas amostras terem sido classificadas como argila de baixa compressibilidade (CL) pela Classificação USCS.

Tabela 5.3 Limites de Atterberg de solos residuais de filito do Estado de São Paulo (Cruz, 1996).

\begin{tabular}{ccccc}
\cline { 2 - 4 } & LL & LP & IP & USCS \\
\hline Silte arenoso & 44 & 30 & 14 & ML \\
Silte pouco arenoso & 44 & 22 & 22 & CL \\
Silte arenoso & 41 & 29 & 12 & CL \\
\hline
\end{tabular}

\subsection{CARACTERIZAÇÃO MINERALÓGICA}

O ensaio de difração de raios X (DRX) mostrou (Figura 5.3) a presença do mineral quartzo $\left(\mathrm{SiO}_{2}\right)$, bem como traços dos argilo-minerais muscovita (mineral do grupo das micas, $\left.\mathrm{KAl}_{2}\left(\mathrm{Si}_{3} \mathrm{Al}\right) \mathrm{O}_{10}(\mathrm{OH}, \mathrm{F})_{2}\right)$, cronstedtita $\quad\left(\mathrm{Fe}_{3} \mathrm{FeSiO}_{4}(\mathrm{OH})_{5}\right)$, caulinita $\left(\mathrm{Al}_{2} \mathrm{Si}_{2} \mathrm{O}_{5}(\mathrm{OH})_{4}\right)$, microclina $\left(\mathrm{KAlSi}_{3} \mathrm{O}_{8}\right)$ e rutilo $\left(\mathrm{TiO}_{2}\right)$. 


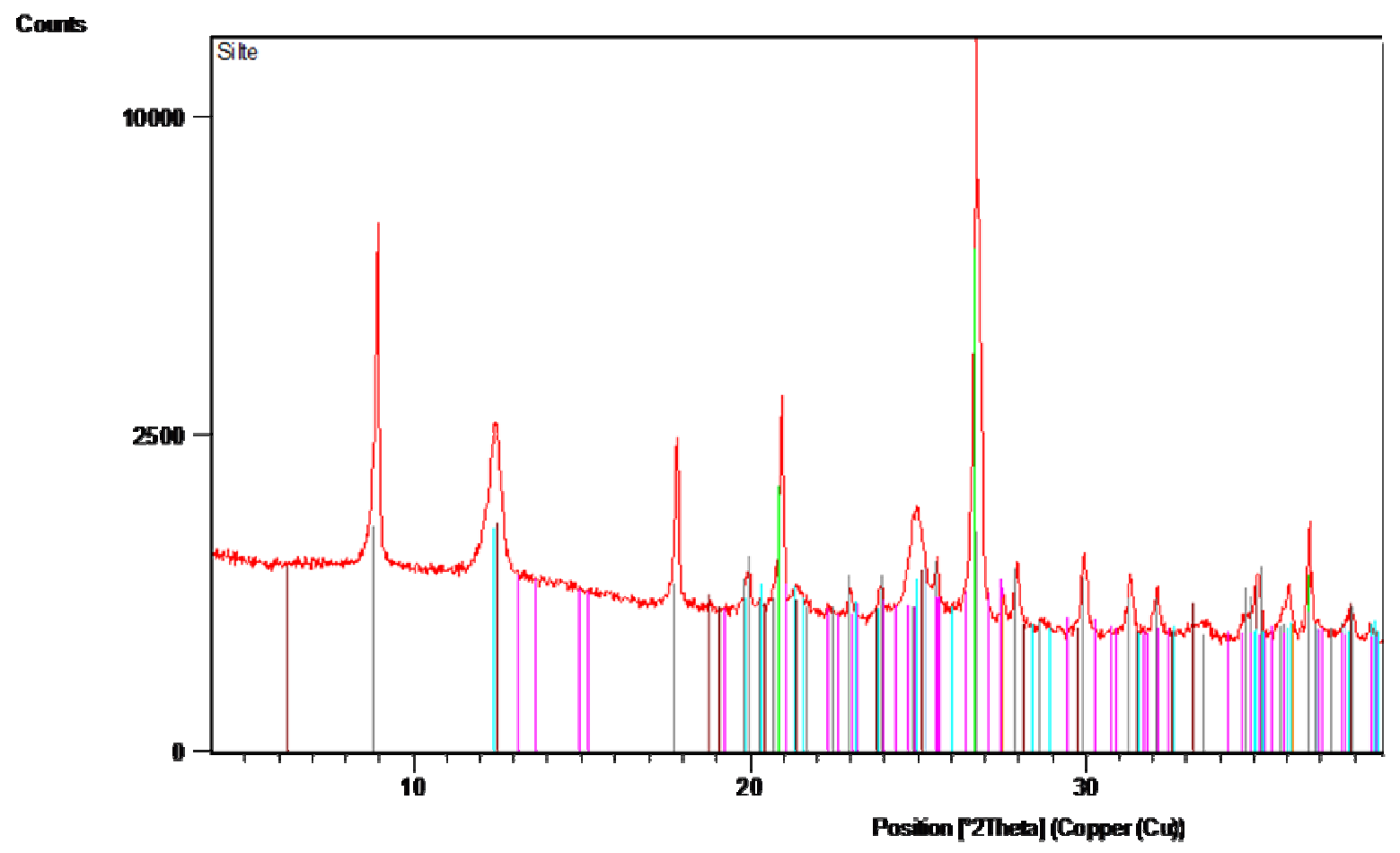

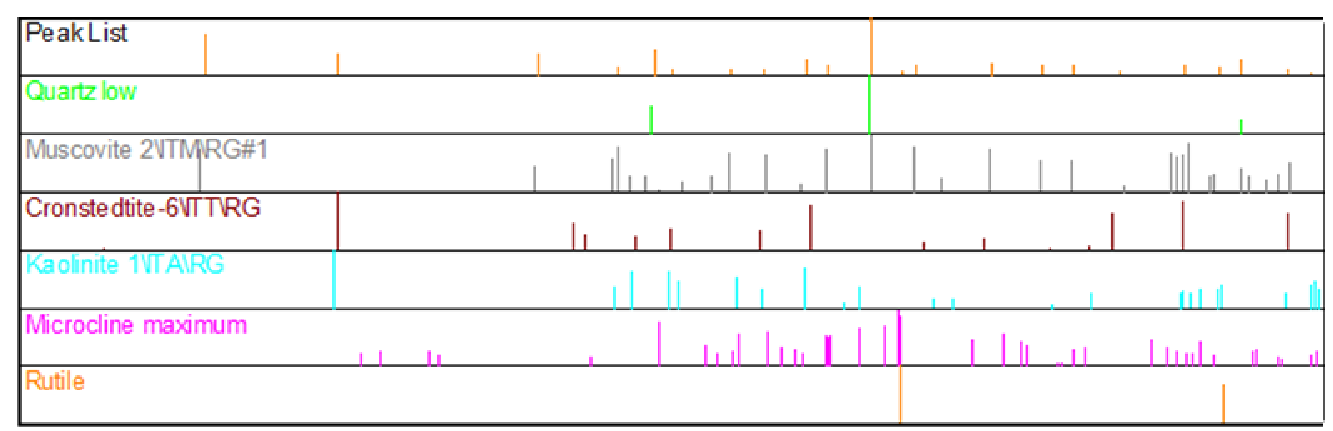

Figura 5.3 Mineralogia do solo natural pelo ensaio de difração de raios X.

Algumas imagens de microscopia eletrônica de varredura estão apresentadas da Figura 5.4 à Figura 5.9. Essas imagens, assim como as demais 33 obtidas, mostram a predominância de quartzo e mica (muscovita), além de feldspato (microclina), óxidos de ferro e KAlSiFeO, não identificado na análise mineralógica. 


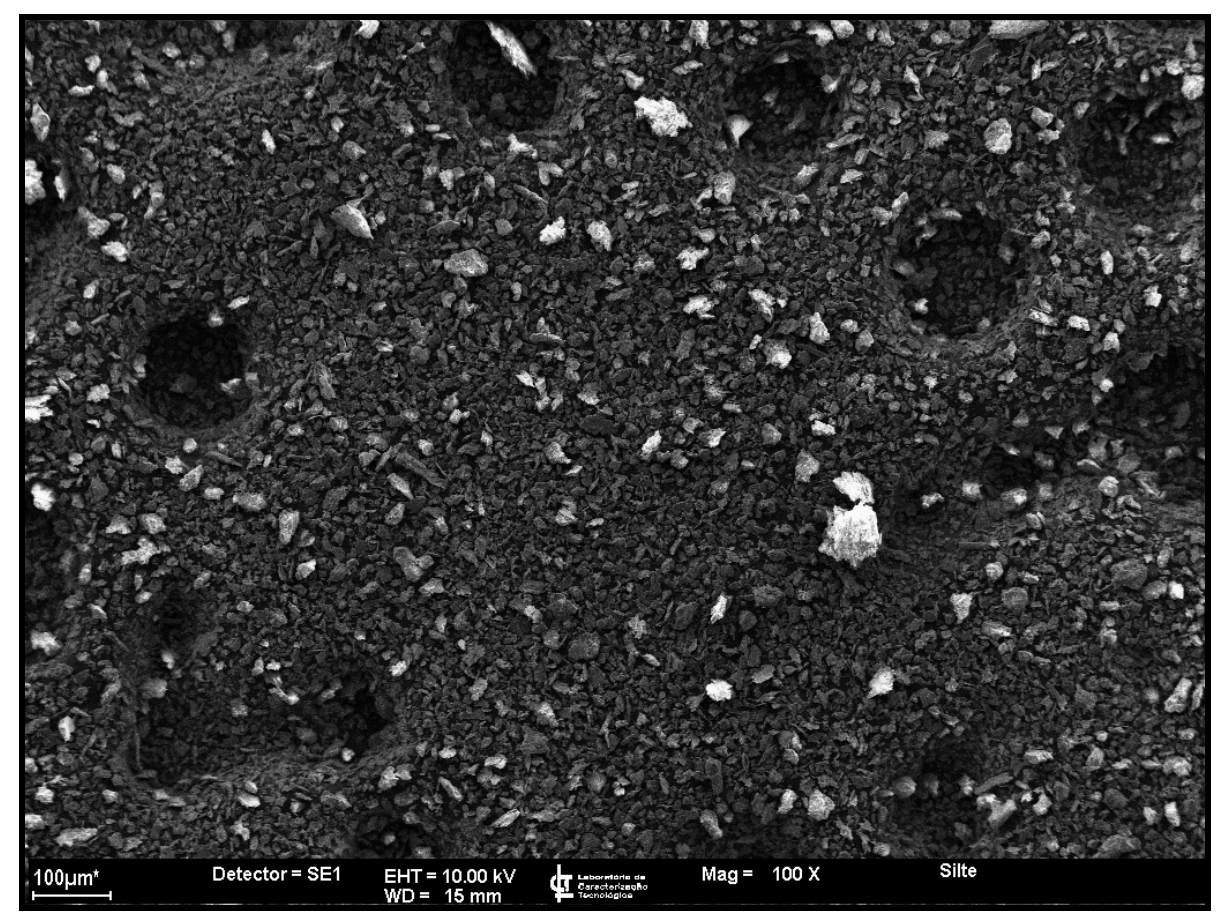

Figura 5.4 Cabeçote do ensaio contendo o solo natural, durante o ensaio MEV.

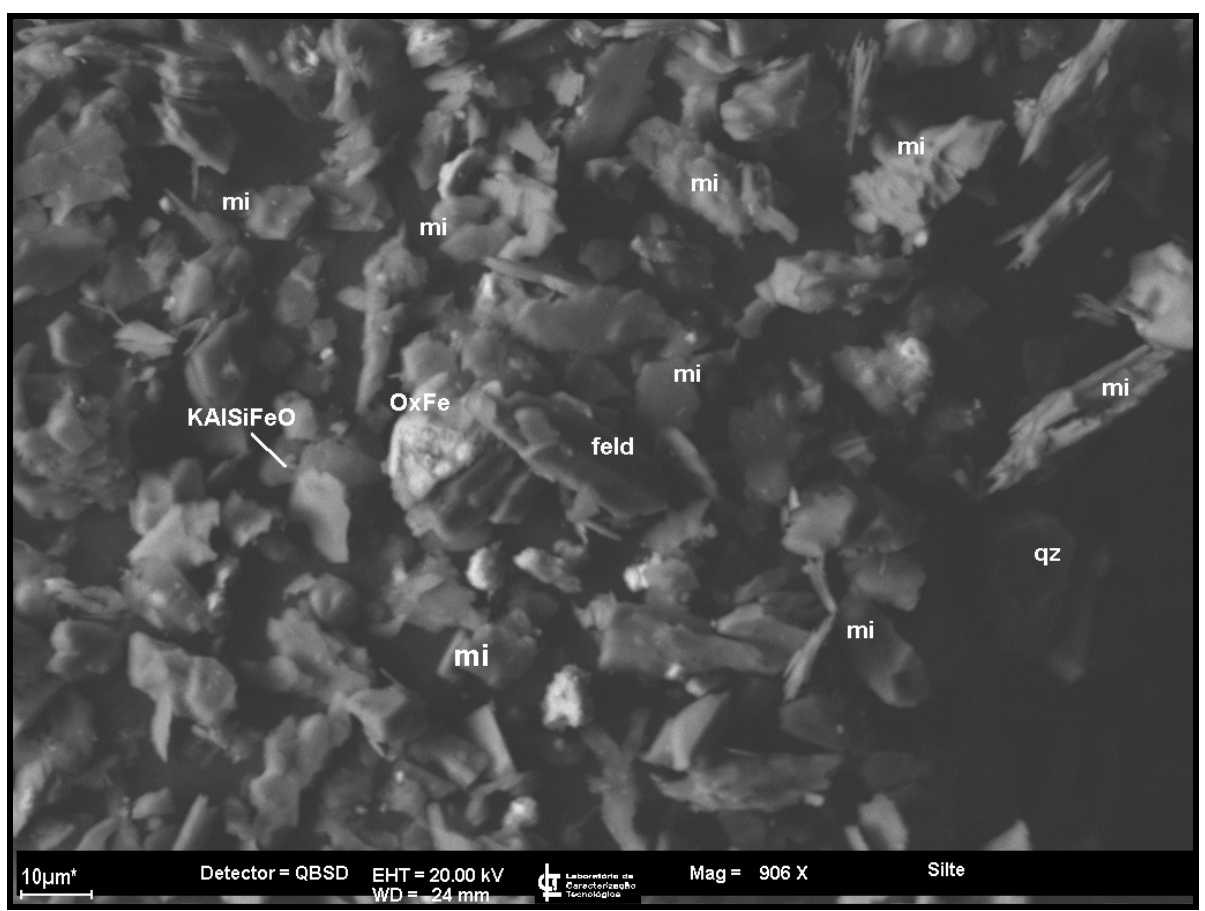

mi: mica; feld: feldspato; qz: quartzo; OxFe: óxido de ferro; $\mathrm{KAlSiFeO}$

Figura 5.5 Minerais encontrados durante a realização do MEV-BSE. 


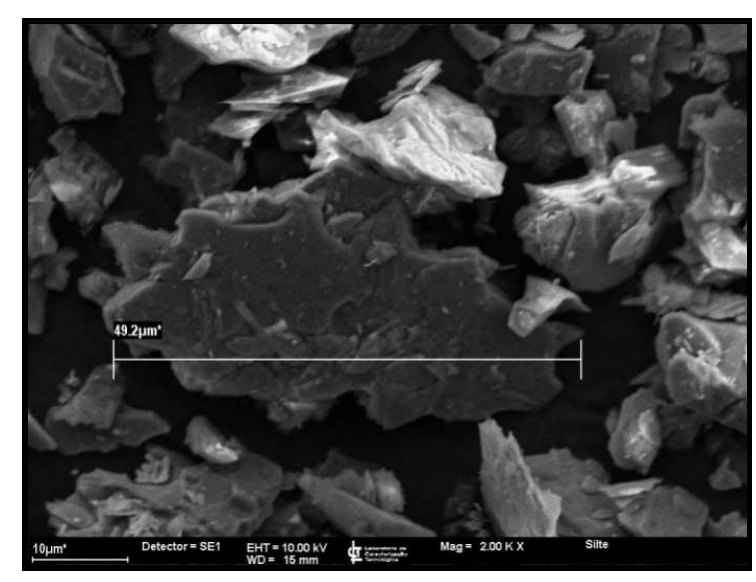

Figura 5.6 MEV - Mica encontrada no solo natural. Aumento de 2.000x.

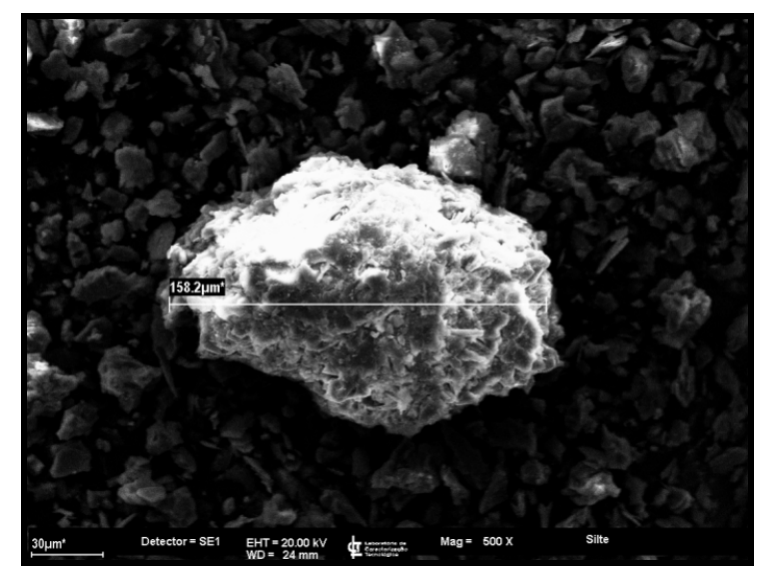

Figura 5.8 MEV - Detalhe do aglomerado de óxido de ferro (impurezas). Aumento de 500x.

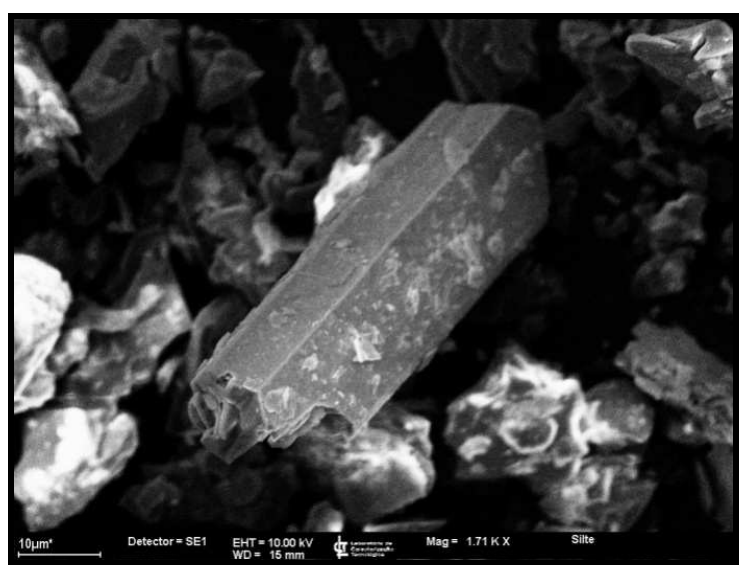

Figura 5.7 MEV - Quartzo impregnado de impurezas. Aumento de 1.710x.

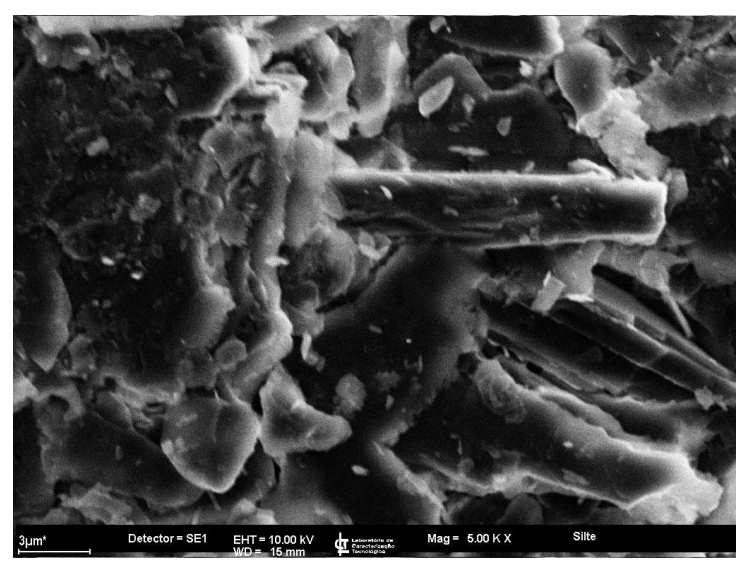

Figura 5.9 MEV - Detalhe do material . Aumento de 5.000x.

\subsection{CARACTERIZAÇÃO QUÍMICA}

Segundo a análise química semiquantitativa por fluorescência de raios X, o solo apresenta predominância de silício, ferro, potássio e alumínio (Tabela 5.4), o que é coerente com os minerais majoritários detectados pela difração de raios $\mathrm{X}$. 
Tabela 5.4 Análise química semiquantitativa do solo natural, valores expressos em \% de óxidos normalizados a $100 \%$.

\begin{tabular}{lclc}
\hline Elemento & Porcentagem & Elemento & Porcentagem \\
\hline $\mathrm{SiO}_{2}$ & 59,6 & $\mathrm{Rb}_{2} \mathrm{O}$ & 0,02 \\
$\mathrm{Fe}_{2} \mathrm{O}_{3}$ & 8,91 & $\mathrm{ZrO}_{2}$ & 0,02 \\
$\mathrm{~K}_{2} \mathrm{O}$ & 4,26 & $\mathrm{ZnO}$ & 0,01 \\
$\mathrm{Al}_{2} \mathrm{O}_{3}$ & 2,11 & $\mathrm{As}_{2} \mathrm{O}_{3}$ & 0,01 \\
$\mathrm{TiO}_{2}$ & 0,77 & $\mathrm{CuO}$ & 0,01 \\
$\mathrm{MgO}$ & 0,38 & $\mathrm{SO}_{3}$ & 0,01 \\
$\mathrm{Na}_{2} \mathrm{O}$ & 0,17 & $\mathrm{CaO}$ & 0,01 \\
$\mathrm{P}_{2} \mathrm{O}_{5}$ & 0,07 & $\mathrm{NiO}$ & 0,01 \\
$\mathrm{MnO}$ & 0,07 & $\mathrm{Y} \mathrm{O}_{3}$ & $<<$ \\
$\mathrm{BaO}$ & 0,07 & $\mathrm{SrO}$ & $<<$ \\
$\mathrm{Cr}_{2} \mathrm{O}_{3}$ & 0,02 & $\mathrm{PF}$ & 5,43 \\
\hline$<$
\end{tabular}

$<<$ : traços (menor que $0,01 \%$ ), PF: Perda ao fogo

$\mathrm{O}$ pH do solo em $\mathrm{H}_{2} \mathrm{O}$ e $\mathrm{KCl}$ é de, respectivamente, 5,1 e 4,1. O teor de matéria orgânica é igual a $1 \mathrm{~g} / \mathrm{kg}(0,1 \%)$. A capacidade de troca catiônica a pH 7 (bases trocáveis $+(\mathrm{H}+\mathrm{Al}))$ é igual a $1,64 \mathrm{cmolc} / \mathrm{kg}$.

Fadigas et al. (2002), analisando 162 solos brasileiros argilosos, observaram que o teor de matéria orgânica foi menor do que $20 \mathrm{~g} / \mathrm{kg}$ para $91 \%$ das amostras; $89 \%$ tinham $\mathrm{pH} \leq 6$ e $60 \%$, $\mathrm{pH} \leq 5$; a capacidade de troca catiônica era menor do que $10 \mathrm{cmolc} / \mathrm{kg}$ para $79 \%$ dos solos, e do que $20 \mathrm{cmolc} / \mathrm{kg}$ para $96 \%$ dos solos.

Um solo saprolítico de gnaisse coletado a $5 \mathrm{~m}$ de profundidade em Minas Gerais, caracterizado como silte arenoso (54\% de silte, $36 \%$ de areia e $8 \%$ de argila), com limites de Atterberg de $\mathrm{LL}=41 \%, \mathrm{LP}=20 \%$ e IP=21\% e classificado como argila inorgânica pouco plástica (CL) pela USCS, apresentou capacidade de troca catiônica de 2,9 cmolc/kg e pH do solo em $\mathrm{H}_{2} \mathrm{O}$ e $\mathrm{KCl}$ de 5,1 e 4,2 (Futai, 2002; Martins, 2005).

Ensaios de caracterização química realizados por Suzuki (2004) em amostra de solo saprolítico contendo caulinita e mica resultaram em pH do solo igual a 4 em $\mathrm{H}_{2} \mathrm{O}$ e em $\mathrm{KCl}$ e capacidade de troca catiônica de 4,2 cmolc/kg. 


\subsection{COMPACTAÇÃO}

Os resultados dos ensaios de compactação encontram-se na Figura 5.10 e na Tabela 5.5.

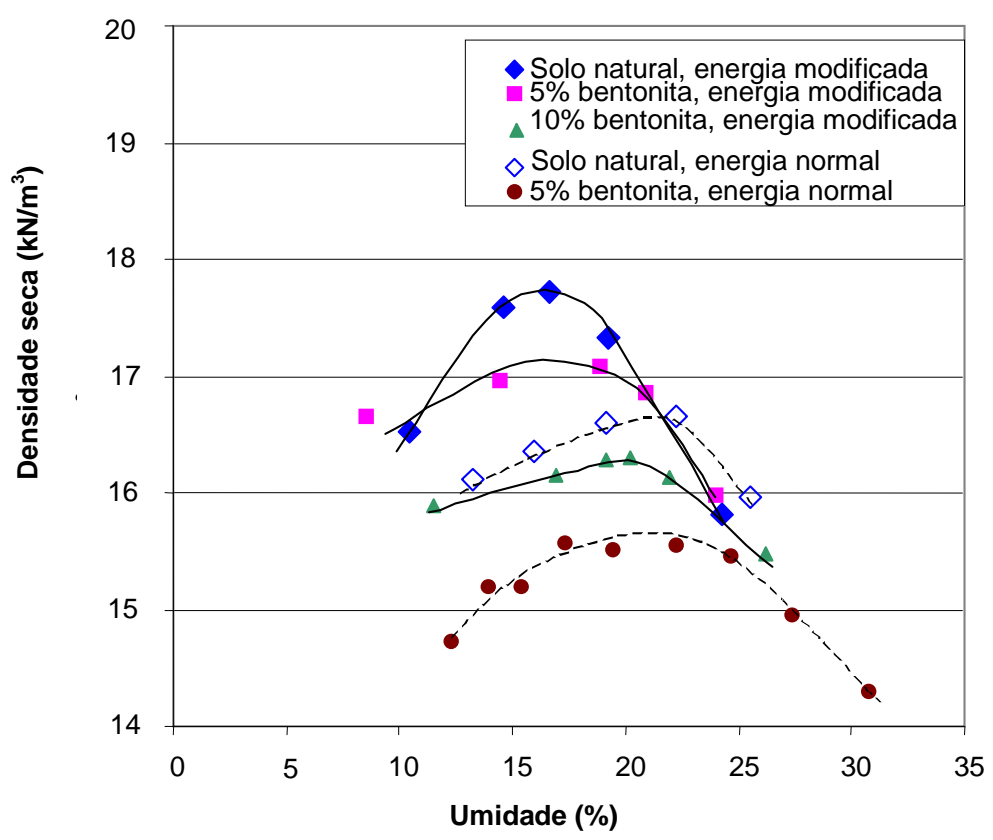

Figura 5.10 Curvas de compactação do solo natural e das misturas de solo com bentonita.

Tabela 5.5 Resultados dos ensaios de compactação.

\begin{tabular}{|c|c|c|c|}
\hline Energia & $\begin{array}{c}\text { Teor de } \\
\text { bentonita } \\
(\%)\end{array}$ & $\begin{array}{c}\text { Teor_de umidade ótimo } \\
\qquad \mathrm{w}_{\mathrm{ot}} \\
(\%)\end{array}$ & $\begin{array}{c}\text { Peso específico aparente } \\
\text { seco máximo } \gamma_{\mathrm{dmax}} \\
\left(\mathbf{k N} / \mathbf{m}^{3}\right)\end{array}$ \\
\hline Normal - coleta $1(*)$ & 0 & 20,00 & 16,33 \\
\hline Normal - coleta 1 & 5 & 21,00 & 15,65 \\
\hline Modificada - coleta $1\left(^{*}\right)$ & 0 & 16,60 & 17,70 \\
\hline- coleta 2 & & 17,00 & 17,50 \\
\hline Modificada - coleta $1(*)$ & 5 & 18,00 & 17,10 \\
\hline Modificada - coleta $1\left(^{*}\right)$ & 10 & 20,00 & 16,27 \\
\hline
\end{tabular}

(*) Ferrari, 2005

O peso específico aparente seco máximo e o teor de umidade ótimo do solo natural estão próximos aos valores obtidos por Pinto et al. (1993), com cinco amostras de filito da Bacia do Rio Ribeira (sul do Estado de São Paulo), respectivamente, 15,4 kN/m³ e 26,1\%. Mori (1983) havia obtido valores de peso específico aparente seco máximo entre 16,0 e $18,2 \mathrm{kN} / \mathrm{m}^{3}$ e de 
teor de umidade ótima entre $14 \%$ e $20 \%$ para solos saprolíticos de gnaisse. Os resultados dos ensaios ficaram próximos, também, dos apresentados por Cruz (1996) para 3 amostras de solos residuais de filito (silte arenoso) do Estado de São Paulo: peso específico seco máximo de $16,10 \mathrm{kN} / \mathrm{m}^{3}$ a $16,55 \mathrm{kN} / \mathrm{m}^{3}$ e teor de umidade ótima entre $17,9 \%$ e $21,7 \%$.

Os resultados dos ensaios de compactação mostram que a adição de bentonita causa o decréscimo do peso específico máximo seco e o aumento da umidade ótima, conforme resultados de Mizuno et al. (2005) para areia siltosa de granito decomposto (vide item 3.4). Isto foi observado para as duas energias de compactação.

\subsection{DENSIDADE DO LIXIVIADO}

Verificou-se que a densidade do lixiviado, determinada a $(20 \pm 3)^{\circ} \mathrm{C}$, apresenta valores próximos à da água: $10,01 \mathrm{kN} / \mathrm{m}^{3}$ e $10,03 \mathrm{kN} / \mathrm{m}^{3}$, para ensaios realizados sem e com vácuo, respectivamente.

\subsection{PERMEABILIDADE}

\subsubsection{Permeabilidade à água}

Os resultados dos ensaios de permeabilidade realizados encontram-se na Figura 5.11, Figura 5.12, Figura 5.13 e Figura 5.15. 


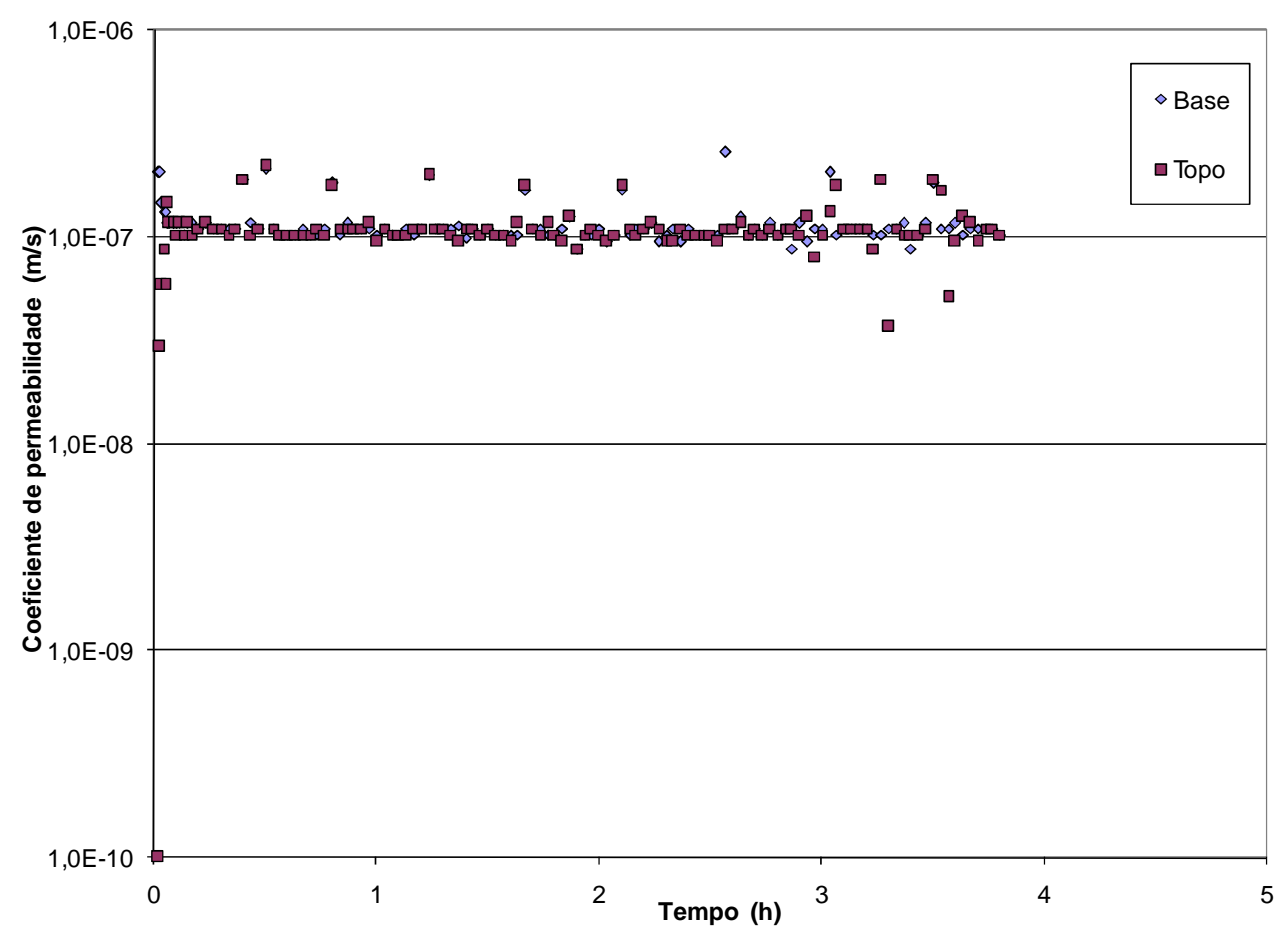

Figura 5.11 Ensaio de permeabilidade com o solo compactado no ramo seco da energia normal.

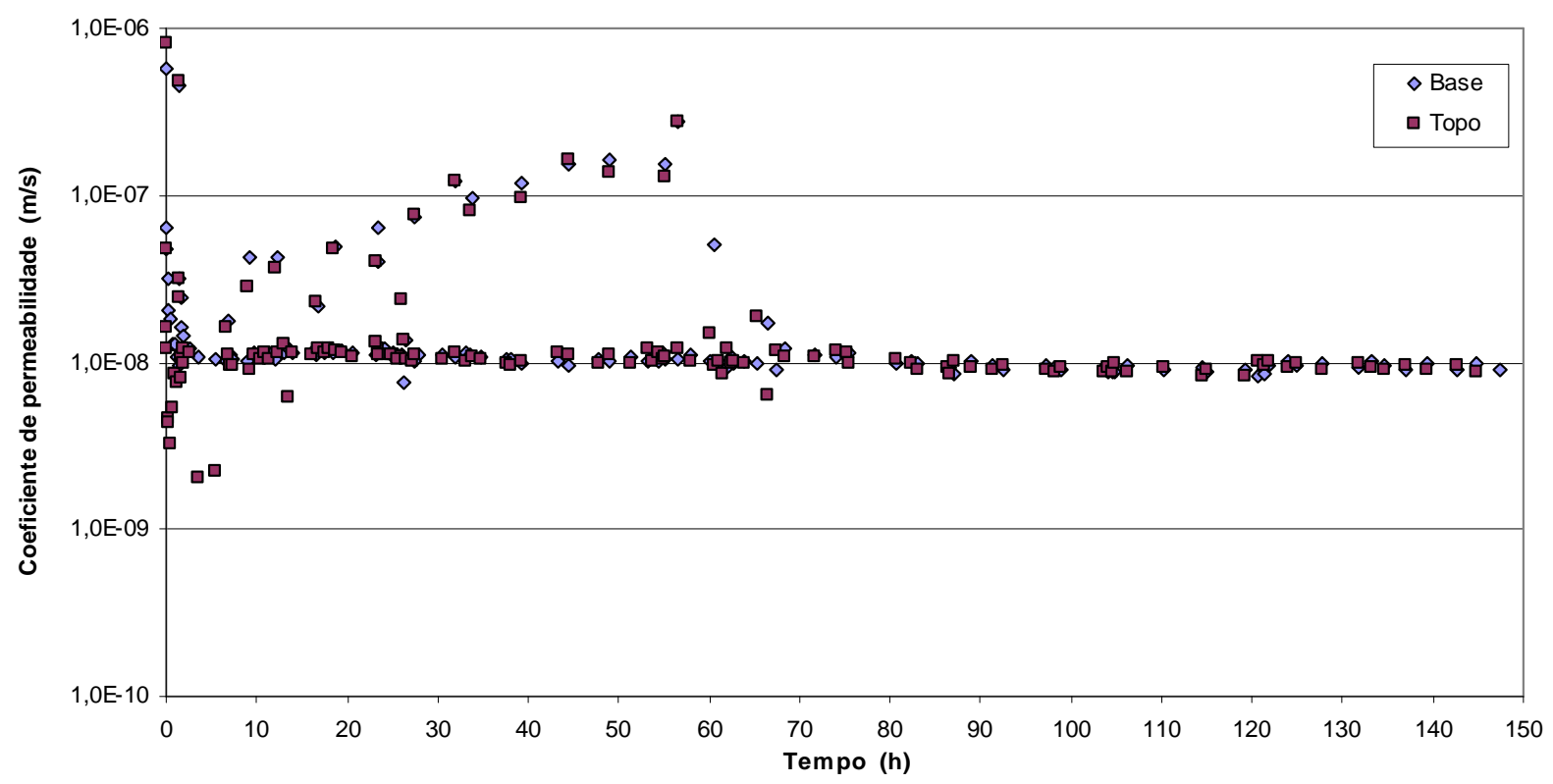

Figura 5.12 Ensaio de permeabilidade com a mistura de solo e 5\% de bentonita compactada no ramo úmido da energia normal. 


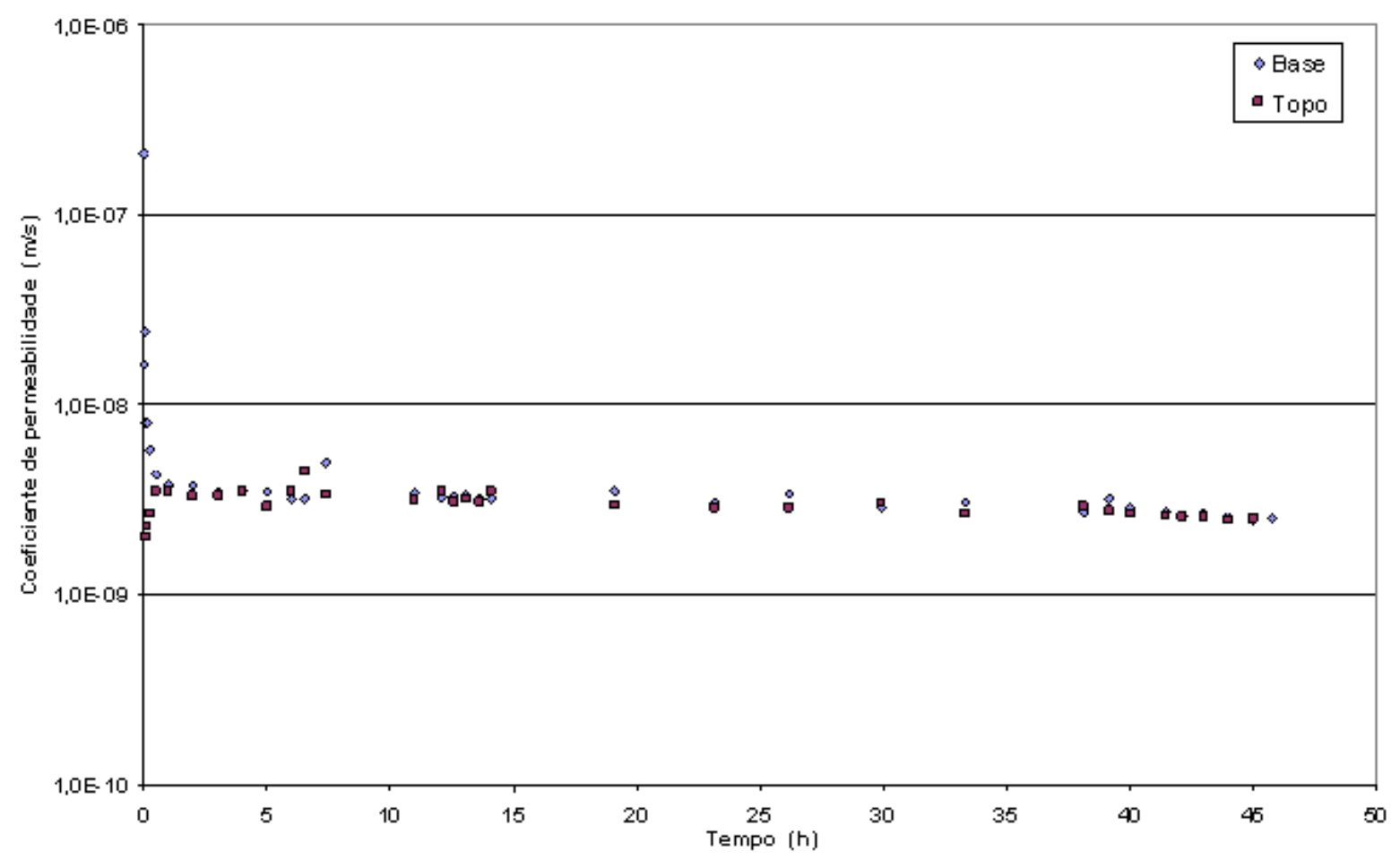

Figura 5.13 Ensaio de permeabilidade com a mistura de solo e 2,5\% de bentonita compactada no ramo úmido da energia modificada.

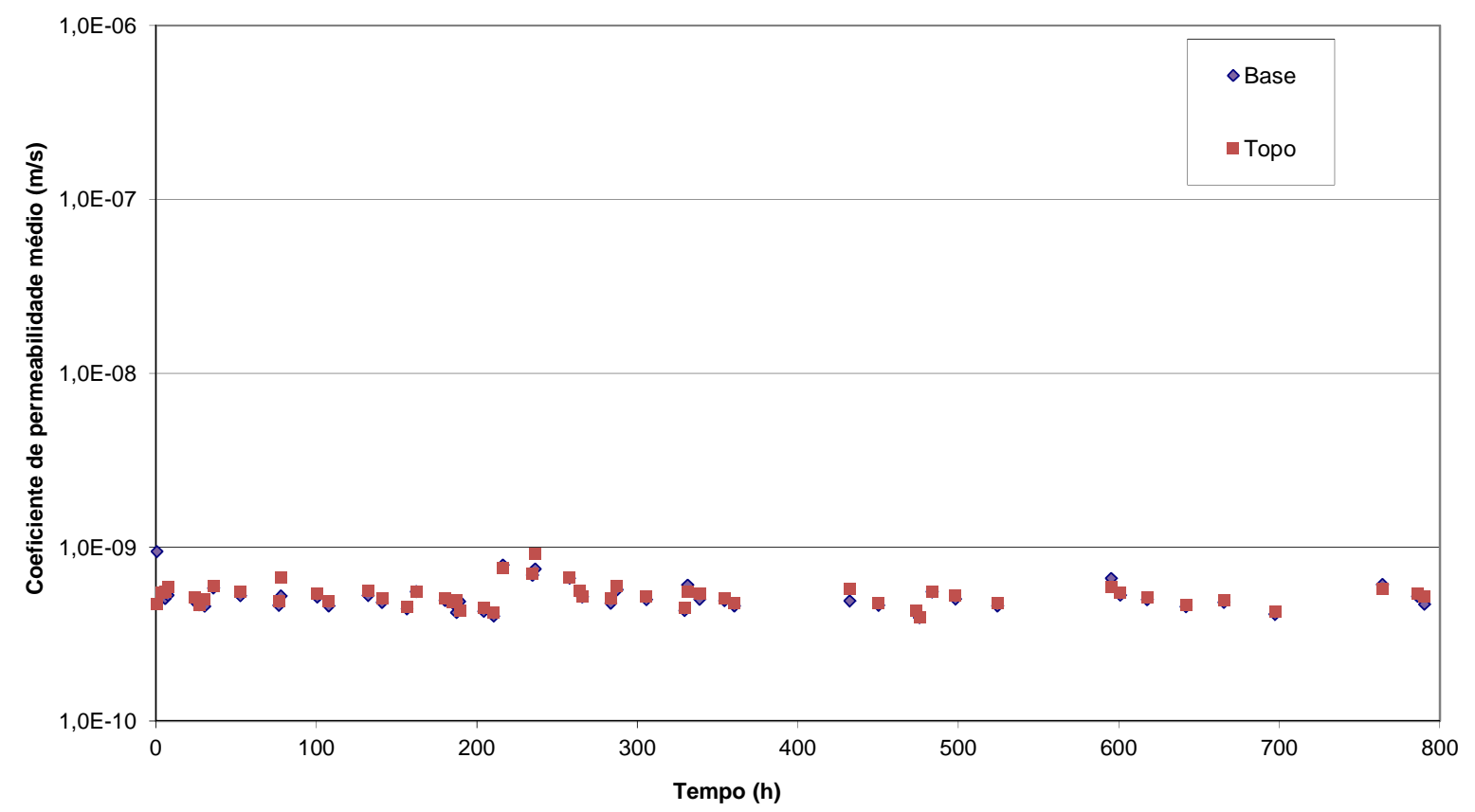

Figura 5.14 Ensaio de permeabilidade com a mistura de solo e 5\% de bentonita compactada no ramo úmido da energia modificada 


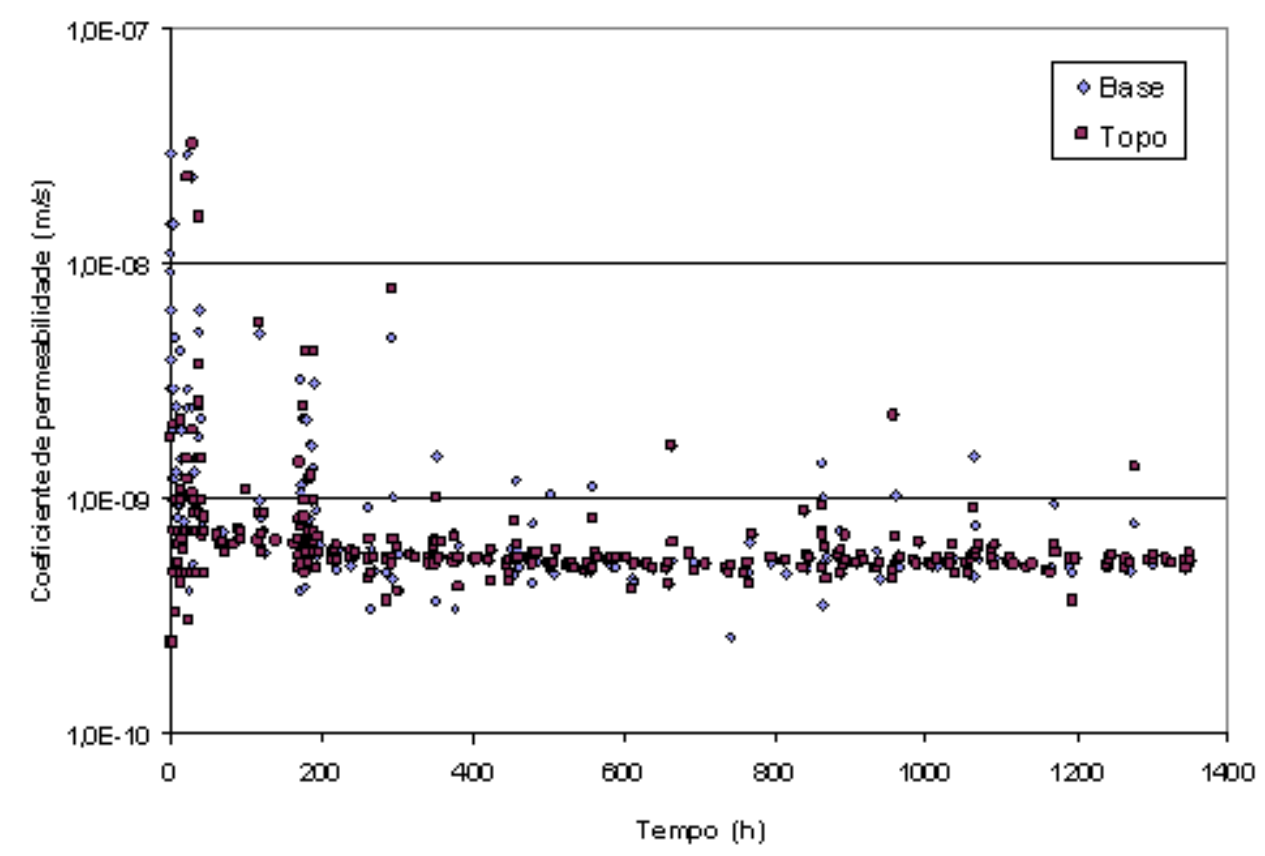

Figura 5.15 Ensaio de permeabilidade com a mistura de solo e 7,5\% de bentonita compactada no ramo úmido da energia modificada.

A Tabela 5.6 e a Figura 5.16 apresentam um resumo dos resultados obtidos.

Tabela 5.6 Resultados dos ensaios de permeabilidade.

\begin{tabular}{ccccccc}
\hline Energia & $\begin{array}{c}\text { Teorde bentonita } \\
(\boldsymbol{\%})\end{array}$ & $\begin{array}{c}\mathbf{w}_{\mathbf{m}} \\
(\boldsymbol{\%})\end{array}$ & $\begin{array}{c}\Delta \mathbf{w} \\
(\boldsymbol{\%})\end{array}$ & $\begin{array}{c}\gamma_{\mathbf{d}} \\
\left(\mathbf{k N} / \mathbf{m}^{3}\right)\end{array}$ & $\begin{array}{c}\mathbf{G C} \\
(\boldsymbol{\%})\end{array}$ & $\begin{array}{c}\mathbf{k} \\
(\mathbf{m} / \mathbf{s})\end{array}$ \\
\hline Normal $\left(^{*}\right)$ & 0 & 23.29 & 3.29 & 15.80 & 97 & $3.5 \times 10^{-8}$ \\
Normal & 0 & 19,56 & -0.44 & 16.33 & 96 & $5.6 \times 10^{-8}$ \\
Normal & 0 & 18.95 & -1.05 & 15.66 & 96 & $1.0 \times 10^{-7}$ \\
Normal & 5 & 21.76 & 1.26 & 15.00 & 96 & $1.0 \times 10^{-8}$ \\
Modificado & 0 & 16,58 & 0 & 17,40 & 98 & $5.2 \times 10^{-8}$ \\
Modificado (*) & 0 & 18.00 & 1.50 & 17.37 & 98 & $2.2 \times 10^{-8}$ \\
Modificado (*) & 0 & 20.68 & 4.18 & 16.88 & 95 & $3.5 \times 10^{-8}$ \\
Modificado & 2,5 & 21.57 & 4.45 & 16.91 & 97 & $2.5 \times 10^{-9}$ \\
Modificado $\left(^{*}\right)$ & 5 & 17.83 & 0.08 & 17.10 & 100 & $6.2 \times 10^{-10}$ \\
Modificado & 5 & 21,19 & 3,2 & 16,41 & 96 & $5,5 \times 10^{-10}$ \\
Modificado & 7,5 & 20.88 & 1.9 & 16,14 & 96,6 & $5.7 \times 10^{-10}$ \\
Modificado $(*)$ & 10 & 24.72 & 5.22 & 15.86 & 97 & $1.7 \times 10^{-10}$ \\
\hline
\end{tabular}

$\mathrm{W}_{\mathrm{m}}=$ umidade de moldagem; $\Delta \mathrm{w}=\mathrm{w}_{\mathrm{m}}-\mathrm{w}_{\mathrm{ot}} ; \gamma_{\mathrm{d}}=$ densidade seca de moldagem; GC=grau de compactação $\left(=\gamma_{\mathrm{d}} / \gamma_{\mathrm{dmax}}\right)$

(*) Ferrari 2005

Observação: Os valores de $\mathrm{w}_{\mathrm{ot}}$ e $\gamma_{\mathrm{dmax}}$ para os teores de bentonita $2,5 \%$ e 7,5\% foram interpolados da Tabela 5.5. 
A Figura 5.16 demonstra que apenas o aumento da energia não diminui o coeficiente de permeabilidade do solo natural no ponto ótimo de compactação. Por outro lado, um teor de $5 \%$ de bentonita adicionado ao silte saprolítico compactado com energia modificada é suficiente para atender as exigências das normas de impermeabilização de aterro sanitário (valor máximo de $10^{-9} \mathrm{~m} / \mathrm{s}$ ). Já na energia normal com $5 \%$ de bentonita o coeficiente de permeabilidade é 10 vezes maior do que exigido.

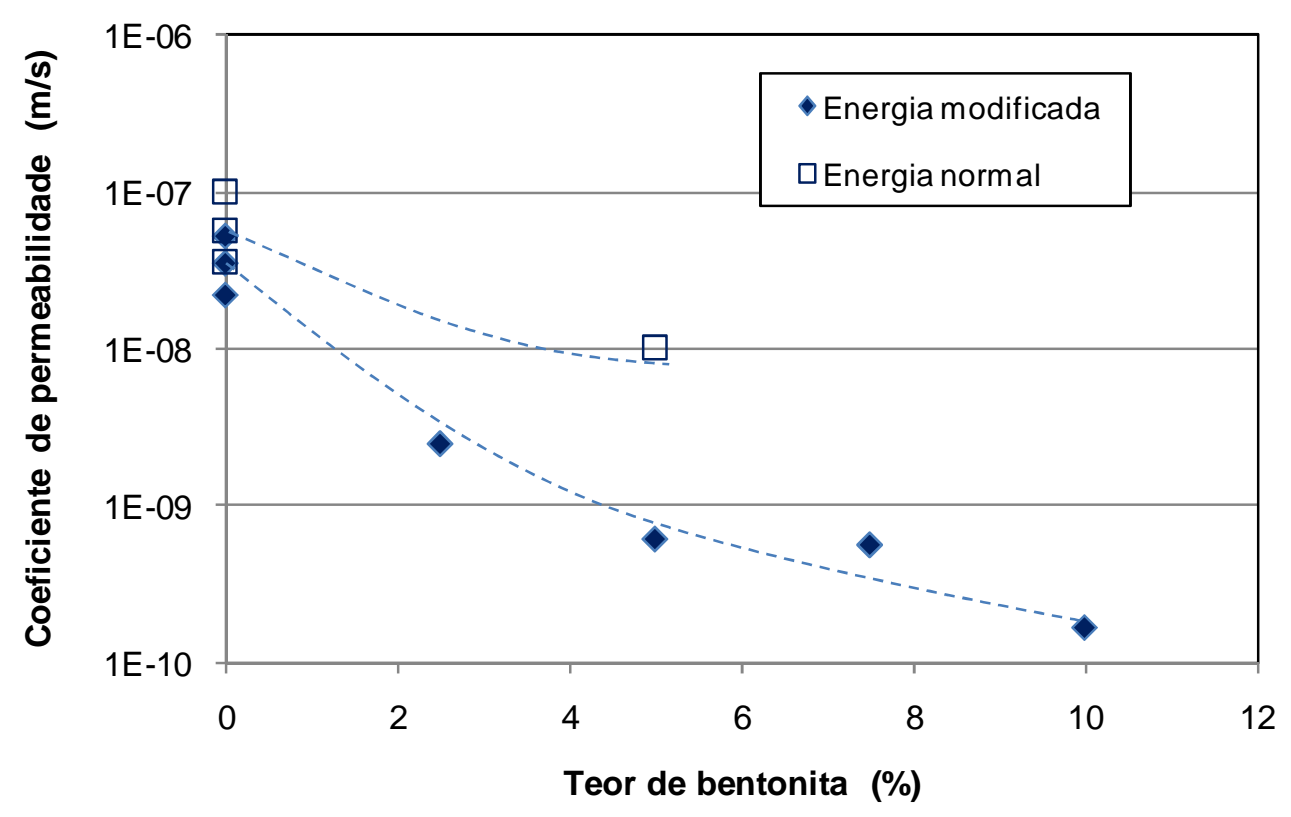

Figura 5.16 Permeabilidade em função do teor de bentonita.

\subsubsection{Permeabilidade ao lixiviado}

Os dados de moldagem dos ensaios de permeabilidade ao lixiviado estão apresentados naTabela 5.7. Os resultados dos ensaios de permeabilidade ao lixiviado estão apresentados na Figura 5.17, na Figura 5.18, na Figura 5.19 e na Figura 5.20. 
Tabela 5.7 Características de moldagem dos corpos-de-prova dos ensaios de permeabilidade ao lixiviado.

\begin{tabular}{ccccc}
\hline & & \multicolumn{3}{c}{ Mistura com 5\% de bentonita } \\
Característica & Solo natural & Ensaio 1 & Ensaio 2 & Ensaio 3 \\
\hline Teor de umidade (\%) & 16,58 & 20,09 & 21,19 & 21,73 \\
Altura inicial do CP $(\mathrm{cm})$ & 5,18 & 5,57 & 4,27 & 2,68 \\
Peso do CP $(\mathrm{g})$ & 405,18 & 434,41 & 328,28 & 202,87 \\
Volume do CP $\left(\mathrm{cm}^{3}\right)$ & 198,91 & 213,21 & 165,08 & 103,99 \\
Densidade natural do solo $\left(\mathrm{g} / \mathrm{cm}^{3}\right)$ & 2,037 & 2,037 & 1,989 & 1,951 \\
Densidade do solo seco $\left(\mathrm{g} / \mathrm{cm}^{3}\right)$ & 1,747 & 1,697 & 1,641 & 1,603 \\
Índice de vazios & 0,57 & 0,63 & 0,67 & 0,71 \\
Grau de saturação $(\%)$ & 80 & 88 & 86 & 84 \\
Grau de compactação $(\%)$ & 100,0 & 95,6 & 96,0 & 93,7 \\
Desvio de umidade $(\%)$ & 0,0 & 2,9 & 3,2 & 3,7 \\
Tempo de ensaio $(\mathrm{h})$ & 4.694 & 7.453 & 6.545 & 3.931 \\
\hline
\end{tabular}

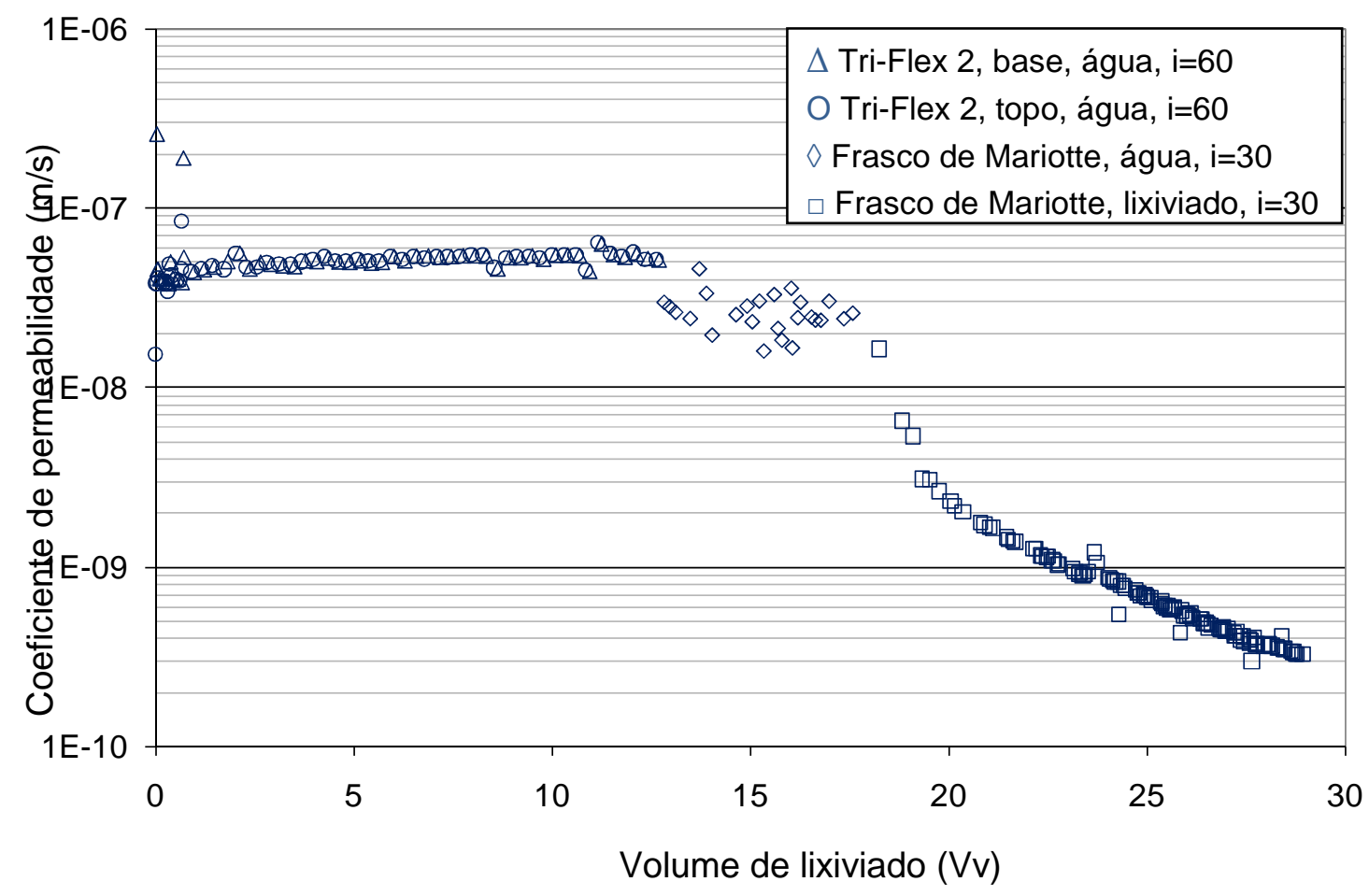

Figura 5.17 Ensaio de permeabilidade do solo natural.

A Figura 5.17 mostra que a permeabilidade inicial à água do solo natural compactado na energia modificada está compatível com os valores do item anterior (Tabela 5.6). A alteração 
do gradiente e alimentação pelo frasco de Mariotte reduziram ligeiramente a permeabilidade (de 5 a $6 \times 10^{-8} \mathrm{~m} / \mathrm{s}$ para de 3 a $4 \times 10^{-8} \mathrm{~m} / \mathrm{s}$ ). A percolação do lixiviado foi diminuindo a permeabilidade significativamente, tendendo a um valor de 1 a $2 \times 10^{-10} \mathrm{~m} / \mathrm{s}$. Este resultado difere das conclusões de autores citados por Nascentes (2006), que observaram aumento do coeficiente de permeabilidade do solo em contato com o lixiviado. Porém, como já discutido no subitem 3.5, tal conclusão não pode ser generalizada, pois as interações solo-lixiviado dependem de muitos mecanismos. Assim como em Hamada et al. (2004), Iwai (2005), Nascentes (2006) e Francisca e Glatstein ( 2010), os resultados dos ensaios de permeabilidade desta dissertação mostraram redução da permeabilidade devida à interação com o lixiviado.

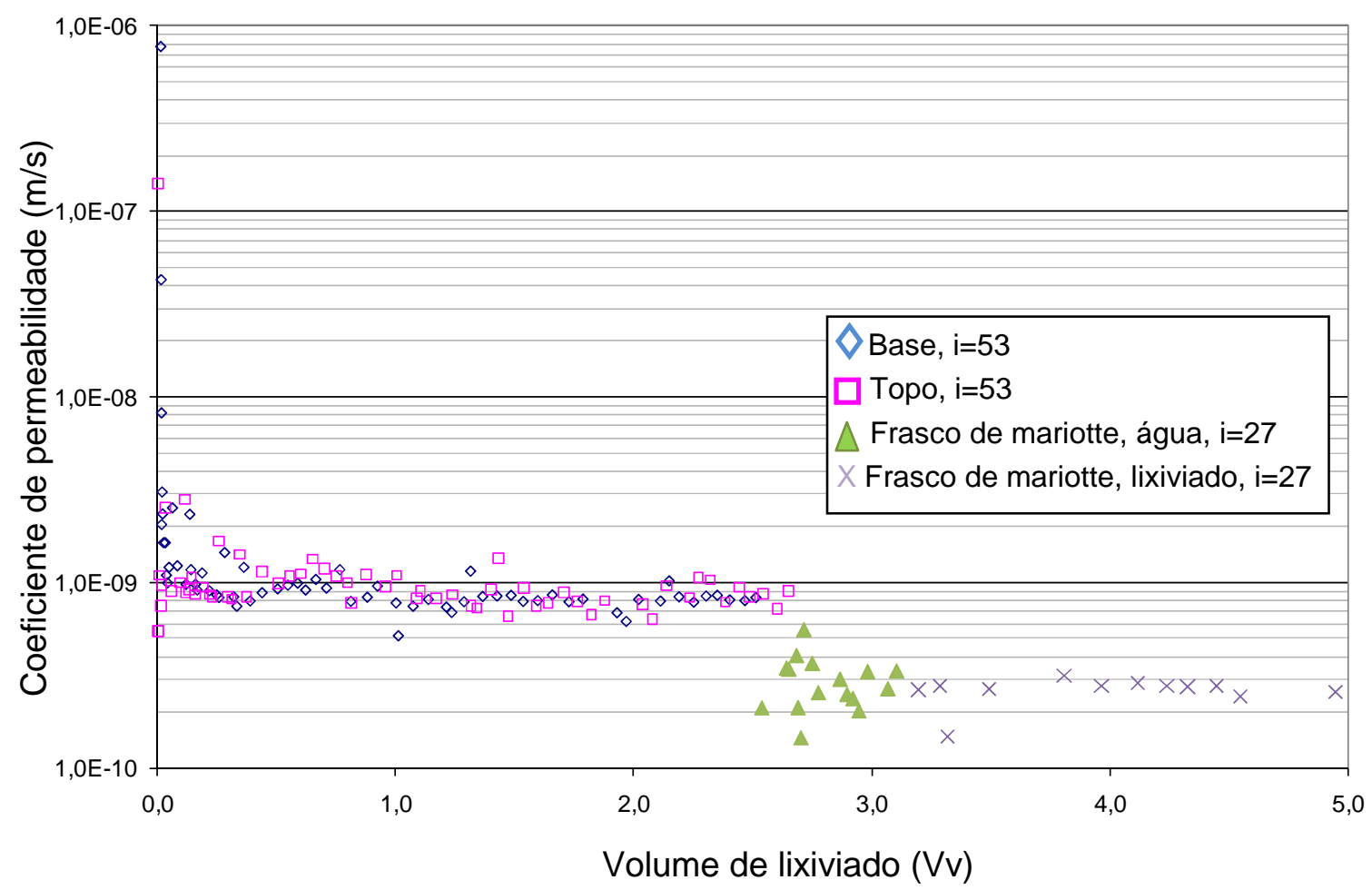

Figura 5.18 Ensaio de permeabilidade da mistura de solo com 5\% de bentonita - Ensaio 1.

O coeficiente de permeabilidade à água da mistura de solo com $5 \%$ de bentonita compactada na energia modificada foi de $8 \times 10^{-10} \mathrm{~m} / \mathrm{s}$ (Figura 5.18), compatível com o valor obtido no item anterior (Tabela 5.6). Neste caso, aparentemente houve um decréscimo da permeabilidade com a redução do gradiente e a alimentação pelo frasco de Mariotte. Constatou-se posteriormente que uma manipulação não avisada do Tri-Flex causou a alteração da calibragem dos transdutores de pressão. Calcula-se que a pressão aplicada na base do corpo-de-prova estava em torno de $65 \mathrm{kPa}$, correspondendo a um gradiente de cerca 
de 120 e a um coeficiente de permeabilidade em torno de $3 \times 10^{-10} \mathrm{~m} / \mathrm{s}$. Assim, a alteração de alimentação e gradiente não causaram modificação na permeabilidade.

Durante a passagem do lixiviado, formaram-se bolhas de gás dentro do corpo-de-prova, possivelmente devido à atividade metabólica de microorganismos. Aparentemente, o lixiviado não modificou a permeabilidade do solo com bentonita; no entanto, os resultados obtidos não são considerados confiáveis devido às bolhas. $\mathrm{O}$ ensaio prosseguiu até ocorrer uma falha no compressor; decidiu-se, então, repetir o ensaio.

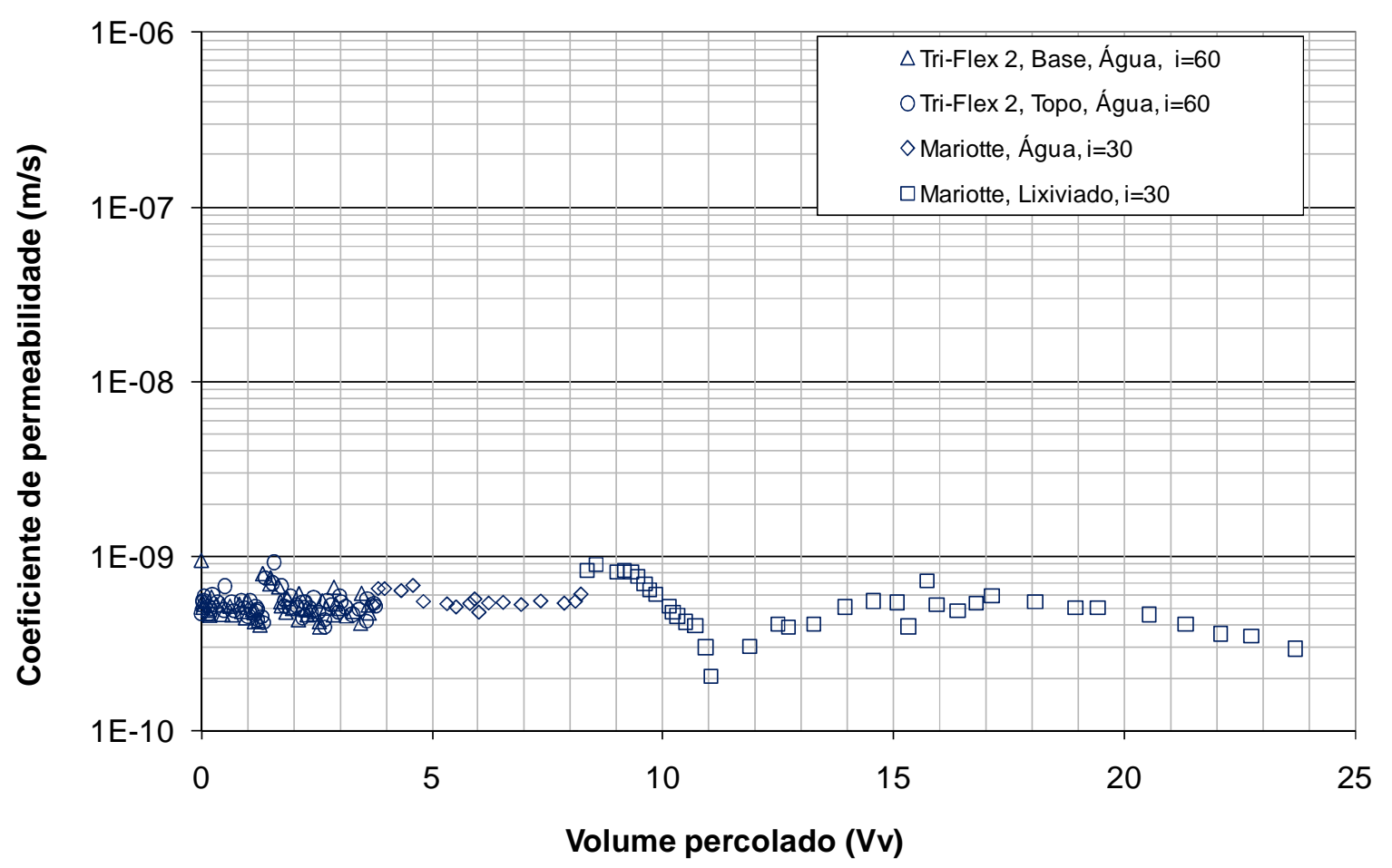

Figura 5.19 Ensaio de permeabilidade da mistura de solo com 5\% de bentonita - Ensaio 2.

A Figura 5.19 mostra que a percolação do lixiviado causou um aumento inicial seguido de uma redução lenta do coeficiente de permeabilidade da mistura ao longo do tempo. Após a passagem de $10,5 \mathrm{~V}_{\mathrm{v}}$ de líquido (volume percolado equivalente a 10,5 vezes o volume de vazios inicial do corpo-de-prova), ou seja, $8,5 \mathrm{~V}_{\mathrm{v}}$ de água e $2 \mathrm{~V}_{\mathrm{v}}$ de lixiviado, o sistema de força do laboratório foi desligado temporariamente, acarretando uma perturbação no ensaio. $\mathrm{O}$ valor final do coeficiente de permeabilidade foi de aproximadamente $3 \times 10^{-10} \mathrm{~m} / \mathrm{s}$. Verificouse após a desmontagem do ensaio que a porosidade do corpo de prova diminuiu de 0,40 , valor obtido na moldagem, para 0,38 no final do ensaio. 
Devido à perturbação ocorrida no ensaio, decidiu-se repeti-lo, porém com um corpo-de-prova de menor espessura e suprimindo a etapa de percolação pelo Tri-Flex.

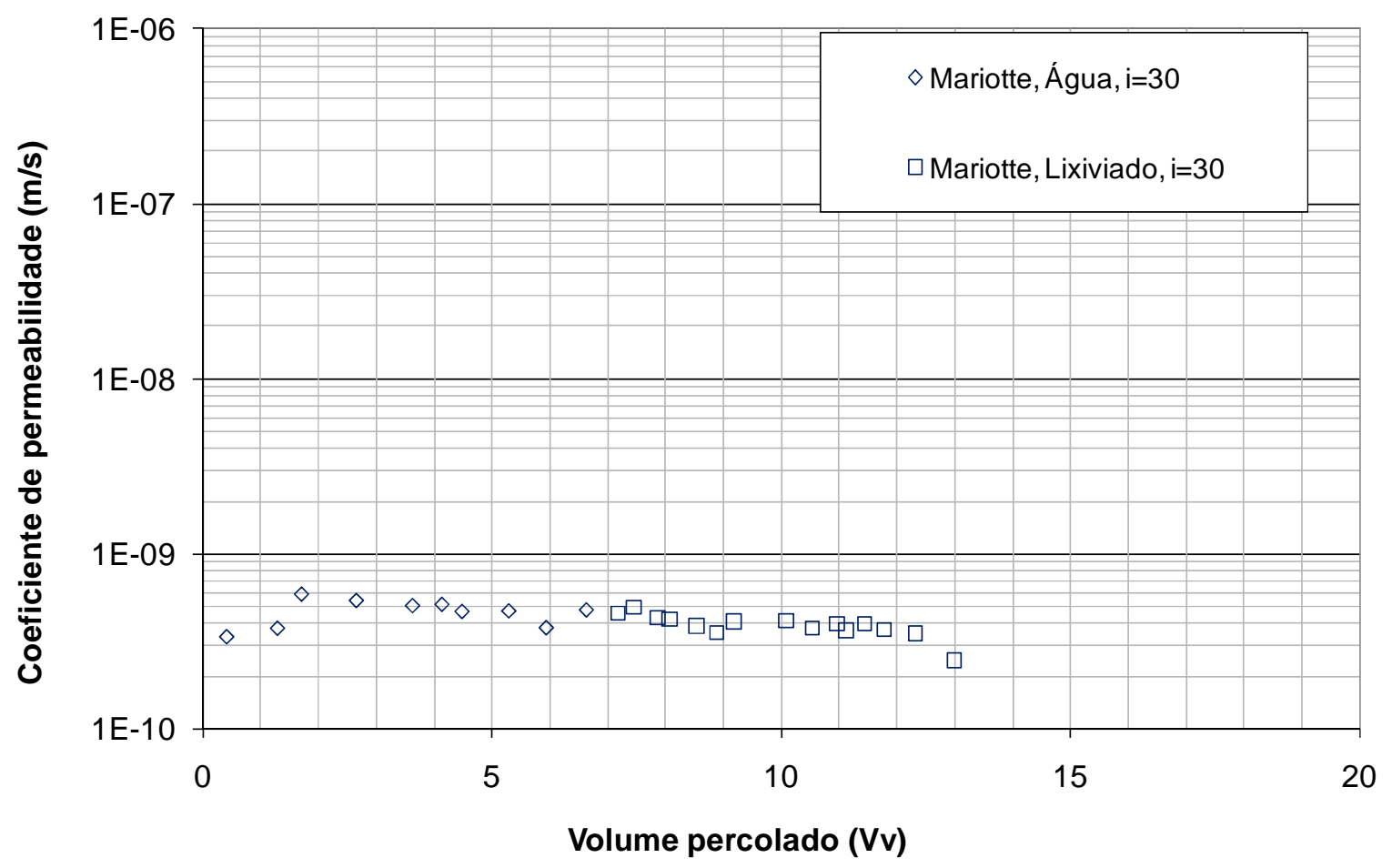

Figura 5.20 Ensaio de permeabilidade da mistura de solo com 5\% de bentonita - Ensaio 3.

O coeficiente de permeabilidade à água foi de 5 a $6 \times 10^{-10} \mathrm{~m} / \mathrm{s}$ (Figura 5.20), compatível com os dois ensaios anteriores (Figura 5.18 e Figura 5.19); após a percolação de 6,5 $\mathrm{V}_{\mathrm{v}}$ de lixiviado, diminuiu para cerca de $3 \times 10^{-10} \mathrm{~m} / \mathrm{s}$.

Observa-se que o valor final de permeabilidade ao lixiviado obtido nos três ensaios com a mistura de solo e $5 \%$ de bentonita compactada na energia modificada foi semelhante, equivalente a uma redução de duas vezes em relação à permeabilidade à água. $\mathrm{O}$ coeficiente de permeabilidade do solo natural compactado na energia modificada, por sua vez, sofre uma redução de cerca de 100 vezes com a percolação de lixiviado, passando de 3 a $4 \times 10^{-8} \mathrm{~m} / \mathrm{s}$ (com frasco de Mariotte e gradiente de 30) para também $3 \times 10^{-10} \mathrm{~m} / \mathrm{s}$. 


\subsection{ENSAIO DE ADENSAMENTO}

Os dados de moldagem dos corpos-de-prova dos ensaios de adensamento estão apresentados na Tabela 5.8. Os resultados dos ensaios de adensamento estão apresentados na Figura 5.21 e na Tabela 5.9.

Tabela 5.8 Características de moldagem dos corpos-de-prova dos ensaios de adensamento.

\begin{tabular}{ccccc} 
Material & \multicolumn{2}{c}{ Solo natural } & \multicolumn{2}{c}{ Mistura com 5\% de bentonita } \\
Fluido & Água & Lixiviado & Água & Lixiviado \\
\hline Umidade natural & 20,16 & 18,86 & 21,73 & 20,88 \\
Altura inicial do CP $(\mathrm{cm})$ & 2,00 & 2,02 & 2,00 & 2,02 \\
Peso do CP $(\mathrm{g})$ & 161,00 & 172,62 & 158,06 & 169,56 \\
Volume do CP $\left(\mathrm{cm}^{3}\right)$ & 79,86 & 85,01 & 79,86 & 85,01 \\
Densidade natural do solo $\left(\mathrm{g} / \mathrm{cm}^{3}\right)$ & 2,016 & 2,031 & 1,979 & 1,995 \\
Densidade do solo seco $\left(\mathrm{g} / \mathrm{cm}^{3}\right)$ & 1,678 & 1,708 & 1,626 & 1,650 \\
Índice de vazios natural & 0,64 & 0,61 & 0,70 & 0,68 \\
Grau de saturação natural $(\%)$ & 87 & 85 & 86 & 85 \\
Grau de Compactação $(\%)$ & 95,9 & 97,6 & 95,1 & 96,5 \\
Desvio de umidade $(\%)$ & 3,2 & 1,9 & 3,7 & 2,9 \\
\hline
\end{tabular}




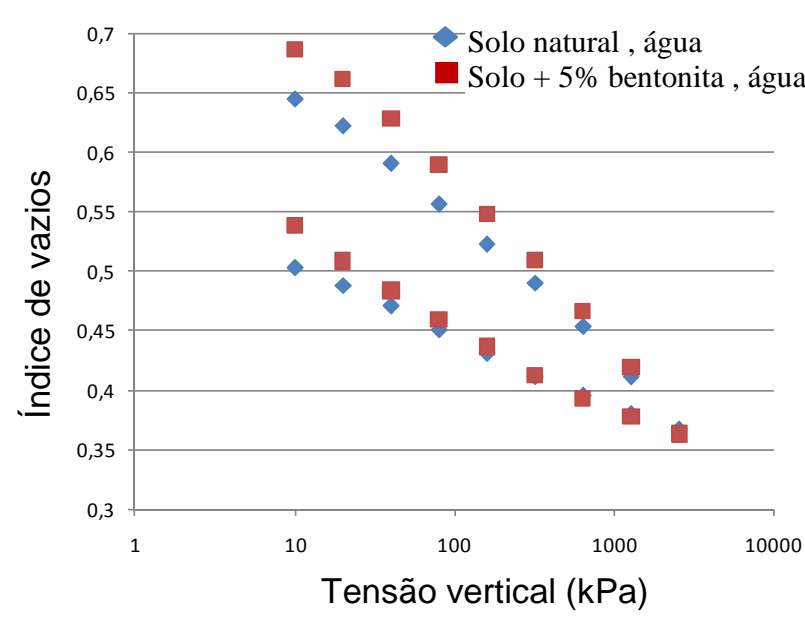

(a)

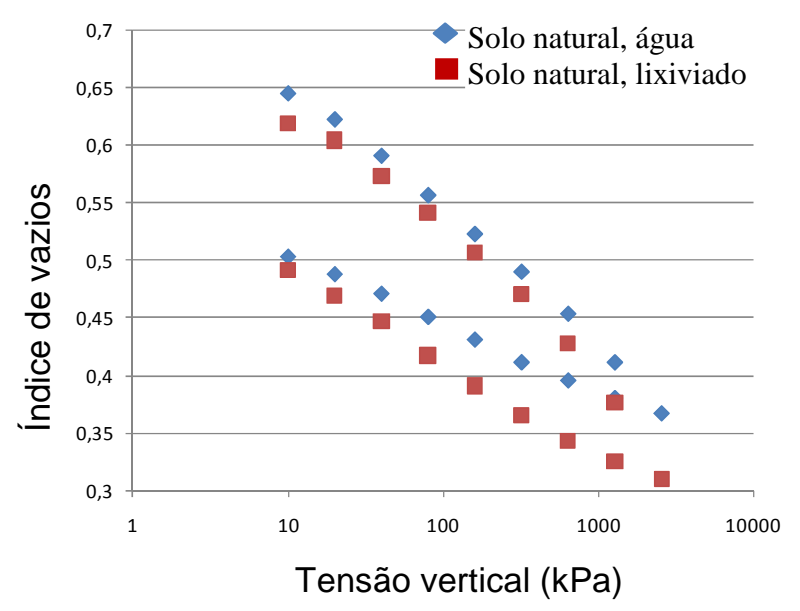

(c)

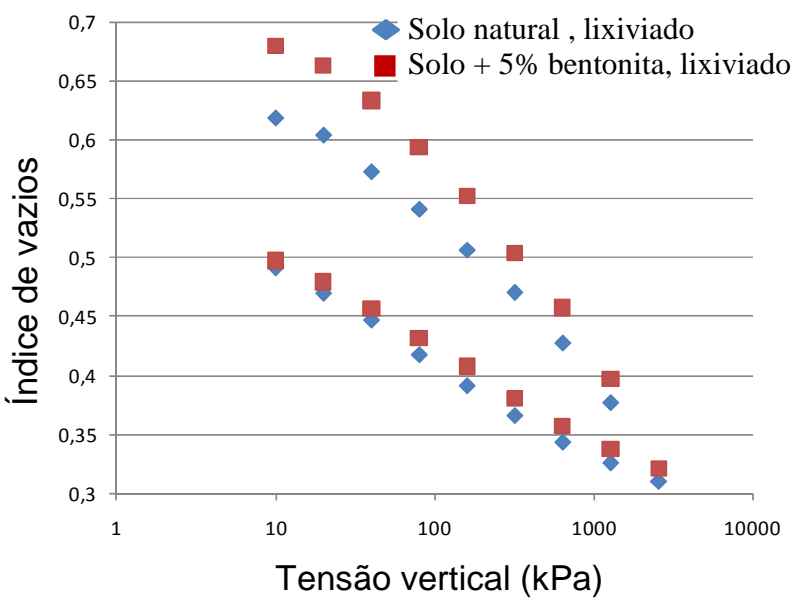

(b)

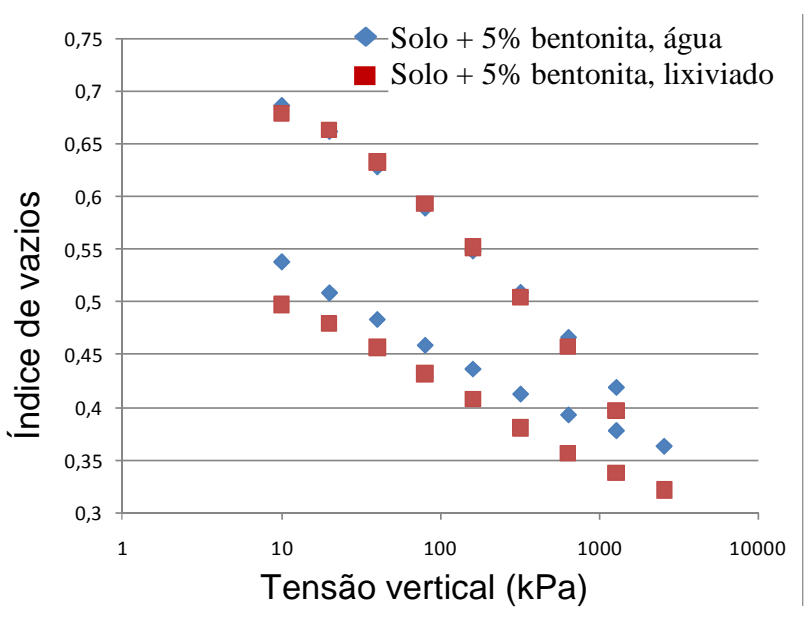

(d)

Figura 5.21 Curvas de adensamento.

Tabela 5.9 Parâmetros determinados pelo ensaio de adensamento.

\begin{tabular}{cccc}
\hline Material & Fluido & $\begin{array}{c}\text { Índice de } \\
\text { compressão (Cc) }\end{array}$ & $\begin{array}{c}\text { Índice de } \\
\text { expansão (Ce) }\end{array}$ \\
\hline Solo Natural & Água & 0,122 & 0,058 \\
Solo Natural & Lixiviado & 0,143 & 0,078 \\
Solo + 5\% de bentonita & Água & 0,145 & 0,074 \\
Solo $+5 \%$ de bentonita & Lixiviado & 0,168 & 0,076 \\
\hline
\end{tabular}

O solo natural compactado ensaiado com água apresentou índices de compressão e expansão semelhantes aos obtidos por Moura e Garcia (1985) para um solo saprolítico caulinítico de filito (0,14 e 0,09, respectivamente). Pinto et al. (1993) citam índice de compressão de 0,20 para uma amostra indeformada de solo residual de filito da Bacia do Rio Ribeira. 
Como se pode observar na Tabela 5.9, ao adicionar 5\% de bentonita ao solo, os índices de compressão e de expansão resultaram $19 \%$ e $28 \%$, respectivamente, mais elevados do que os do solo natural, pois devido à adição de finos a amostra se torna mais plástica e expansiva.

Os índices de compressão e de expansão do solo natural compactado após contato com o lixiviado foram, respectivamente, $17 \%$ e $36 \%$ maiores do que com água. Os índices de compressão e de expansão da mistura de solo com $5 \%$ de bentonita compactada após contato com o lixiviado foram, respectivamente, $16 \%$ e $3 \%$ maiores do que com água.

Os índices de compressão dos materiais estudados são baixos, típicos de solos compactados. A adição de bentonita e o contato com o lixiviado aumentam a compressibilidade, mas esta ainda assim está dentro de valores de baixa compressibilidade. Observa-se que os valores de índice de expansão do solo natural com lixiviado e da mistura de solo com 5\% de bentonita com água e com lixiviado são praticamente iguais e ligeiramente superiores ao do solo natural com água.

\subsection{CISALHAMENTO DIRETO}

\subsubsection{Cisalhamento com água}

Os dados de moldagem dos corpos-de-prova dos ensaios realizados utilizando água como líquido de inundação estão apresentados na Tabela 5.10. Os resultados dos ensaios de cisalhamento estão apresentados na Figura 5.22 e Figura 5.23. A Tabela 5.11 e a Figura 5.24 apresentam um resumo dos resultados dos ensaios de cisalhamento. 
Tabela 5.10 Dados de moldagem dos corpos-de-prova dos ensaios de cisalhamento direto

\begin{tabular}{|c|c|c|c|}
\hline \multirow{3}{*}{ Solo natural } & $\begin{array}{c}\text { Tensão aplicada } \\
50 \mathrm{kPa}\end{array}$ & $\begin{array}{l}\text { Densidade do solo seco, } \mathrm{kN} / \mathrm{m}^{3} \\
\text { Densidade dos grãos, } \mathrm{kN} / \mathrm{m}^{3} \\
\text { Índice de vazios } \\
\text { Grau de saturação, } \% \\
\text { Grau de compactação, } \% \\
\text { Umidade média, } \% \\
\text { Desvio de umidade, } \% \\
\end{array}$ & $\begin{array}{l}17,01 \\
27,75 \\
0,63 \\
75 \\
96,1 \\
17,14 \\
0,54 \\
\end{array}$ \\
\hline & $\begin{array}{c}\text { Tensão aplicada } \\
100 \mathrm{kPa}\end{array}$ & $\begin{array}{l}\text { Densidade do solo seco, } \mathrm{kN} / \mathrm{m}^{3} \\
\text { Densidade dos grãos, } \mathrm{kN} / \mathrm{m}^{3} \\
\text { Índice de vazios } \\
\text { Grau de saturação, \% } \\
\text { Grau de compactação, \% } \\
\text { Umidade média, \% } \\
\text { Desvio de umidade, \% } \\
\end{array}$ & $\begin{array}{l}16,07 \\
27,75 \\
0,73 \\
64 \\
90,1 \\
16,86 \\
0,26 \\
\end{array}$ \\
\hline & $\begin{array}{c}\text { Tensão aplicada } \\
200 \mathrm{kPa}\end{array}$ & $\begin{array}{l}\text { Densidade do solo seco, } \mathrm{kN} / \mathrm{m}^{3} \\
\text { Densidade dos grãos, } \mathrm{kN} / \mathrm{m}^{3} \\
\text { Índice de vazios } \\
\text { Grau de saturação, \% } \\
\text { Grau de compactação, \% } \\
\text { Umidade média, \% } \\
\text { Desvio de umidade, \% }\end{array}$ & $\begin{array}{l}16,38 \\
27,75 \\
0,70 \\
66 \\
92,5 \\
16,58 \\
-0,02\end{array}$ \\
\hline \multirow{3}{*}{$\begin{array}{l}\text { Mistura de solo } \\
\text { com } 5 \% \text { de } \\
\text { bentonita }\end{array}$} & $\begin{array}{c}\text { Tensão aplicada } \\
50 \mathrm{kPa}\end{array}$ & $\begin{array}{l}\text { Densidade do solo seco, } \mathrm{kN} / \mathrm{m}^{3} \\
\text { Densidade dos grãos, } \mathrm{kN} / \mathrm{m}^{3} \\
\text { Índice de vazios } \\
\text { Grau de saturação, \% } \\
\text { Grau de compactação, \% } \\
\text { Umidade média, \% } \\
\text { Desvio de umidade, \% }\end{array}$ & $\begin{array}{l}16,76 \\
27,65 \\
0,66 \\
76 \\
98,0 \\
18,00 \\
0,00\end{array}$ \\
\hline & $\begin{array}{l}\text { Tensão aplicada } \\
100 \mathrm{kPa}\end{array}$ & $\begin{array}{l}\text { Densidade do solo seco, } \mathrm{kN} / \mathrm{m}^{3} \\
\text { Densidade dos grãos, } \mathrm{kN} / \mathrm{m}^{3} \\
\text { Índice de vazios } \\
\text { Grau de saturação, \% } \\
\text { Grau de compactação, \% } \\
\text { Umidade média, \% } \\
\text { Desvio de umidade, \% }\end{array}$ & $\begin{array}{l}16,68 \\
27,65 \\
0,66 \\
77 \\
97,5 \\
18,36 \\
0,36 \\
\end{array}$ \\
\hline & $\begin{array}{l}\text { Tensão aplicada } \\
200 \mathrm{kPa}\end{array}$ & $\begin{array}{l}\text { Densidade do solo seco, } \mathrm{kN} / \mathrm{m}^{3} \\
\text { Densidade dos grãos, } \mathrm{kN} / \mathrm{m}^{3} \\
\text { Índice de vazios } \\
\text { Grau de saturação, \% } \\
\text { Grau de compactação, \% } \\
\text { Umidade média, \% } \\
\text { Desvio de umidade, \% }\end{array}$ & $\begin{array}{l}16,88 \\
27,65 \\
0,64 \\
79 \\
98,7 \\
18,31 \\
0,31\end{array}$ \\
\hline
\end{tabular}




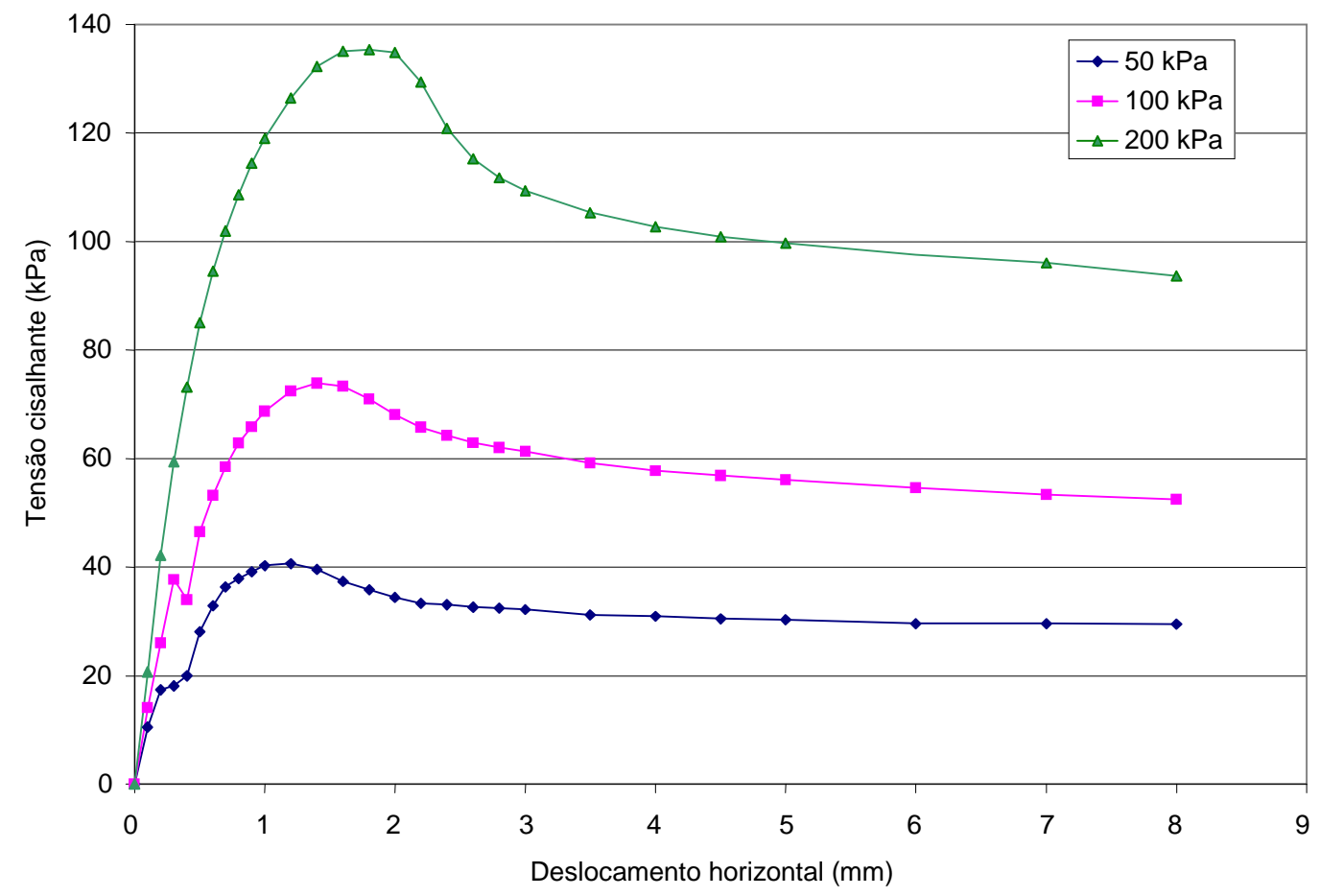

(a)

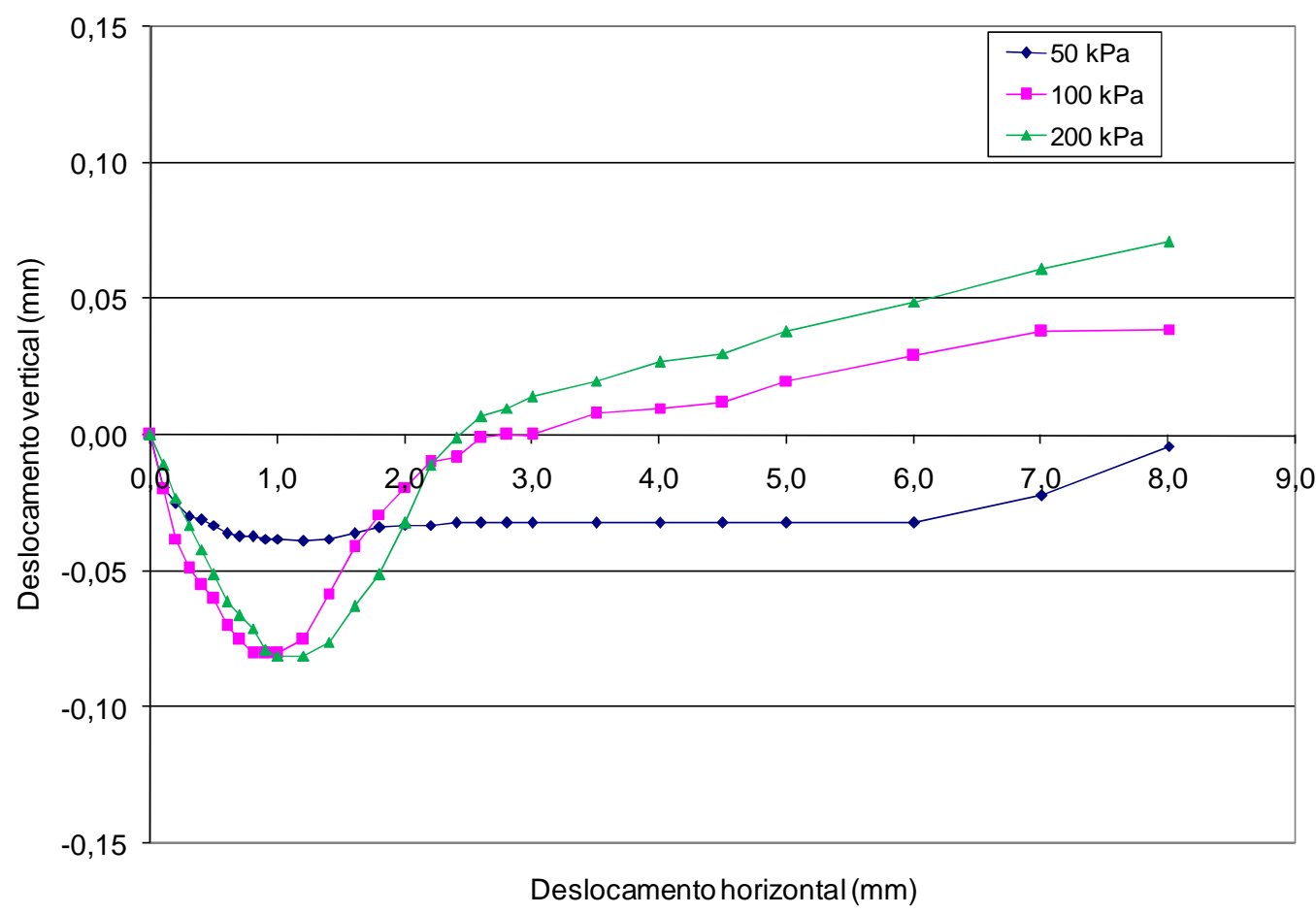

(b)

Figura 5.22 Resultados dos ensaios de cisalhamento direto com o solo natural inundado com água: (a) tensão cisalhante em função do deslocamento horizontal; (b) deslocamento vertical em função do deslocamento horizontal. 


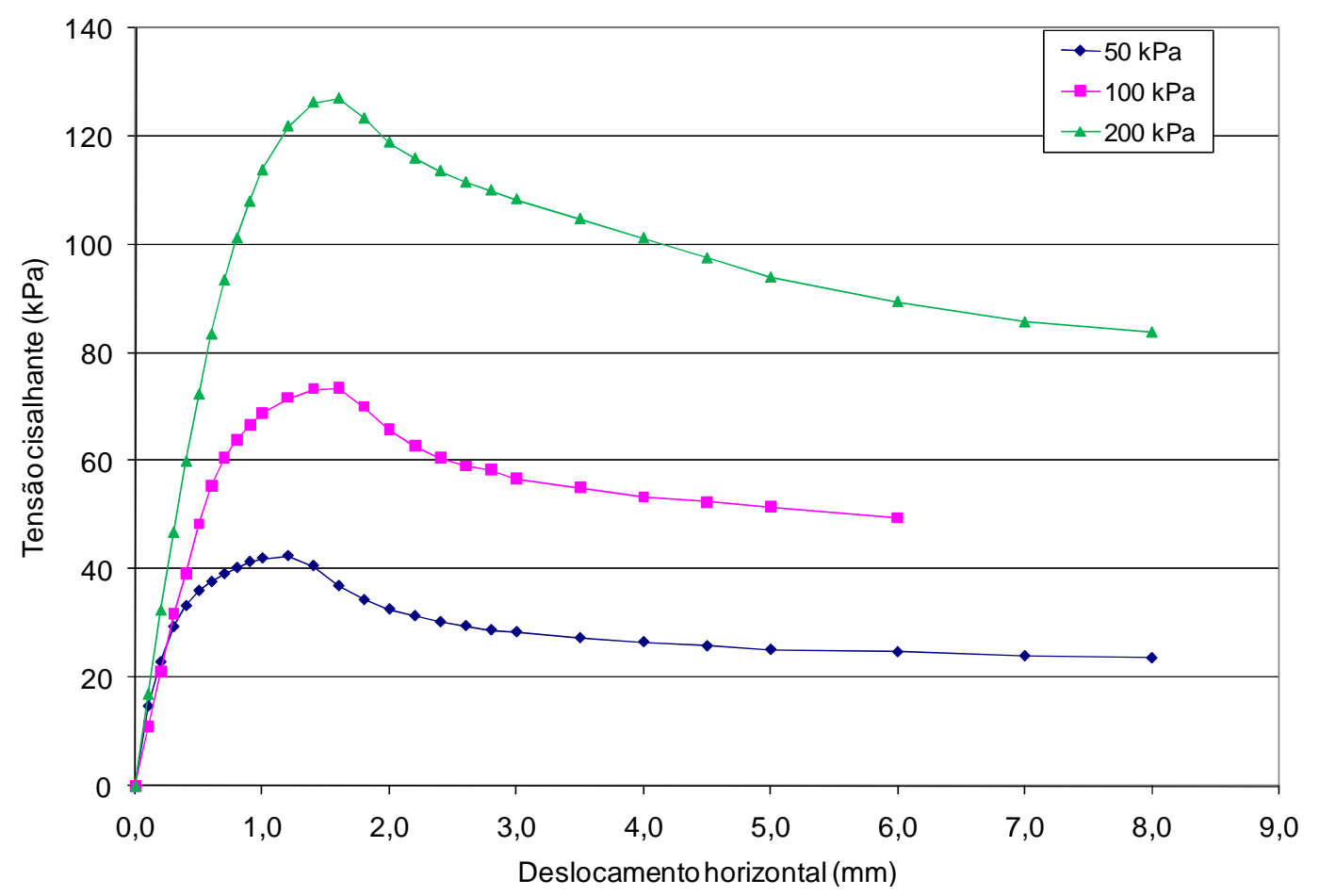

(a)

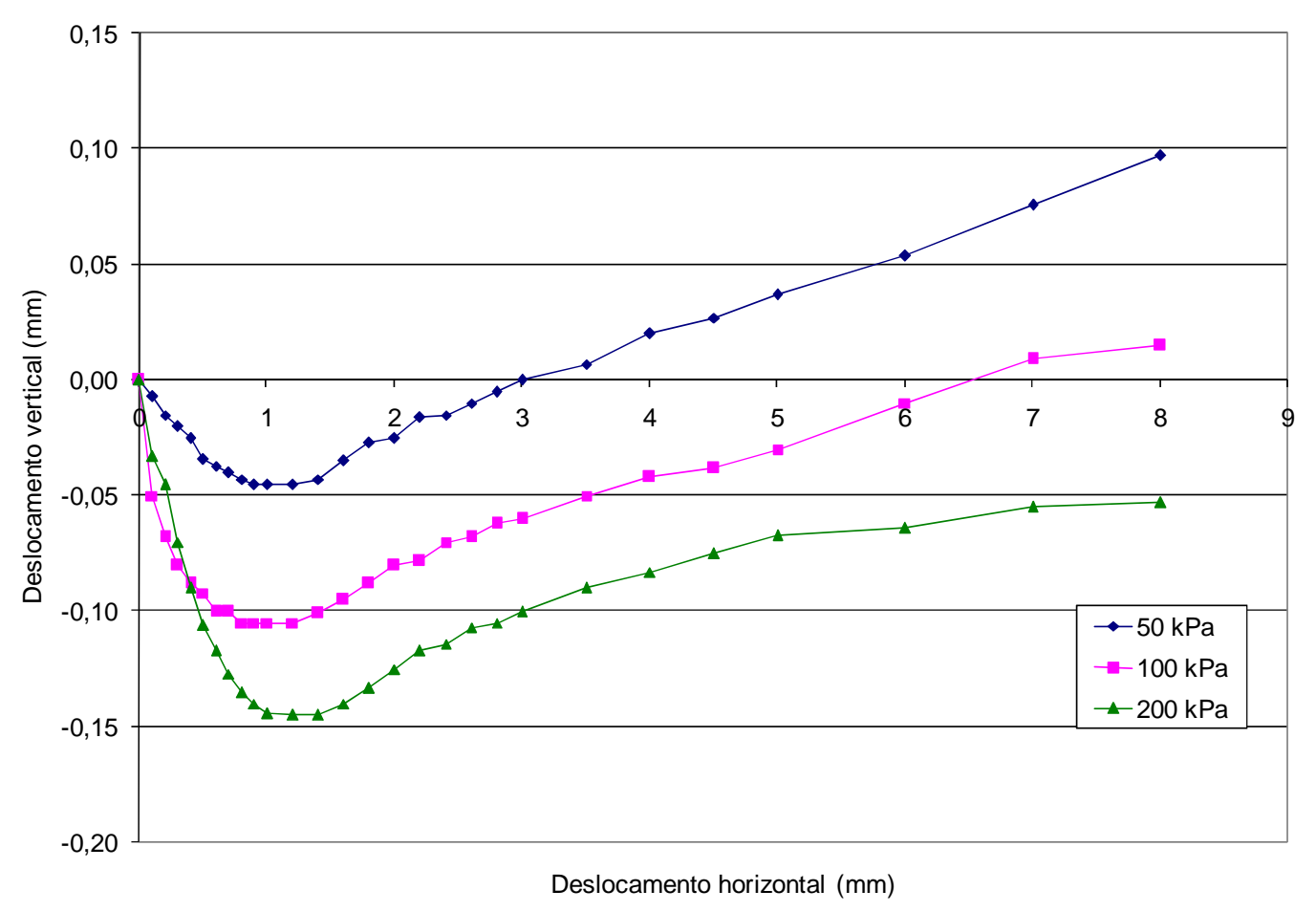

(b)

Figura 5.23 Resultados dos ensaios de cisalhamento direto com a mistura com 5\% de bentonita inundada com água: (a) tensão cisalhante em função do deslocamento horizontal; (b) deslocamento vertical em função do deslocamento horizontal. 


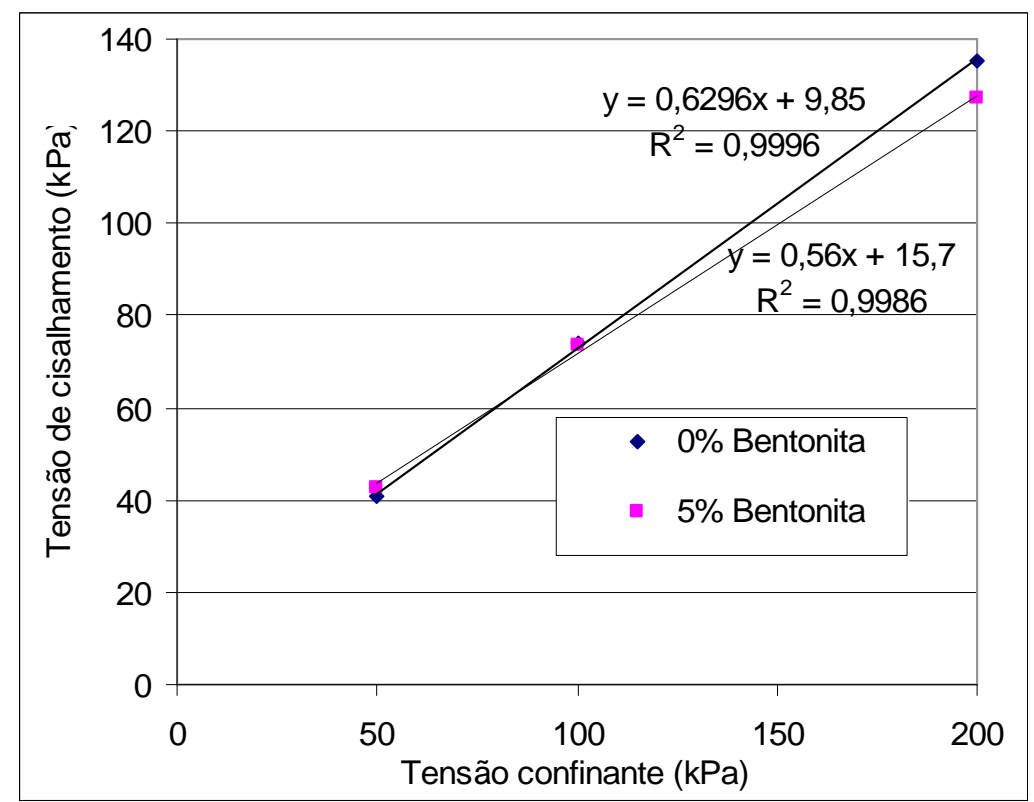

Figura 5.24 Envoltórias de resistência -inundação com água.

Tabela 5.11 Envoltórias de resistência - inundação com água.

\begin{tabular}{cccc}
\hline Material & $\boldsymbol{\sigma}\left(\mathbf{k N} / \mathbf{m}^{\mathbf{2}}\right)$ & $\boldsymbol{\tau}_{\text {max }}\left(\mathbf{k N} / \mathbf{m}^{2}\right)$ & Resistência ao Cisalhamento \\
\hline \multirow{3}{*}{ Solo Natural } & 50 & 40.6 & $\mathrm{~s}=9.9+\sigma \operatorname{tg} 32.2^{\circ}(\mathrm{kPa})$ \\
& 100 & 73.9 & \\
\hline \multirow{2}{*}{ Solo contendo 5\% } & 200 & 135.4 & $\mathrm{~s}=15.7+\sigma \operatorname{tg} 29.2^{\circ}(\mathrm{kPa})$ \\
Bentonita & 100 & 42.5 & \\
& 200 & 73.5 & \\
\hline
\end{tabular}

A envoltória de cisalhamento do solo natural mostra uma coesão de 9,9 kPa e ângulo de atrito de $32,2^{\circ}$. Este ângulo de atrito está dentro da faixa de valores, de $30^{\circ}$ a $38^{\circ}$, para argilas com índice de plasticidade igual a 10 (Pinto, 2002). Por outro lado, valores usuais de intercepto de coesão para esses solos situam-se em torno de 5 a $50 \mathrm{kPa}$, embora este valor não tenha significado físico de coesão (Pinto, 2002).

Da Tabela 5.11 e da Figura 5.24 pode-se verificar um aumento significativo da coesão, de $59 \%$, na mistura contendo $5 \%$ de bentonita, o que era de se esperar já que foi adicionada uma maior quantidade de finos plásticos ao solo. Já no ângulo de atrito houve uma redução ao se adicionar a bentonita, de $9 \%$, porém menos significativa do que o aumento de coesão. $\mathrm{Na}$ faixa de tensões estudada, as duas envoltórias de resistência são praticamente coincidentes. 
Estes comportamentos estão de acordo com Lukiantchuki e Esquivel (2007), que observaram que a coesão e ângulo de atrito para uma areia aumentaram e diminuíram, respectivamente, com a adição de bentonita.

A diferença na resistência ao cisalhamento não é muito notável quando se compara o silte saprolítico e a mistura de silte saprolítico com $5 \%$ de bentonita. Isto é considerado vantajoso visto que a permeabilidade da mistura silte saprolítico com $5 \%$ de bentonita diminuiu e a resistência ao cisalhamento manteve-se praticamente igual.

\subsubsection{Cisalhamento com lixiviado}

Os dados de moldagem dos corpos-de-prova dos ensaios utilizando o lixiviado como líquido de inundação estão apresentados na Tabela 5.12. Os resultados estão apresentados na Figura 5.25 e na Figura 5.26. A Figura 5.27 e a Tabela 5.13 apresentam um resumo dos resultados dos ensaios de cisalhamento. 
Tabela 5.12 Dados de moldagem dos corpos-de-prova inundados com lixiviado.

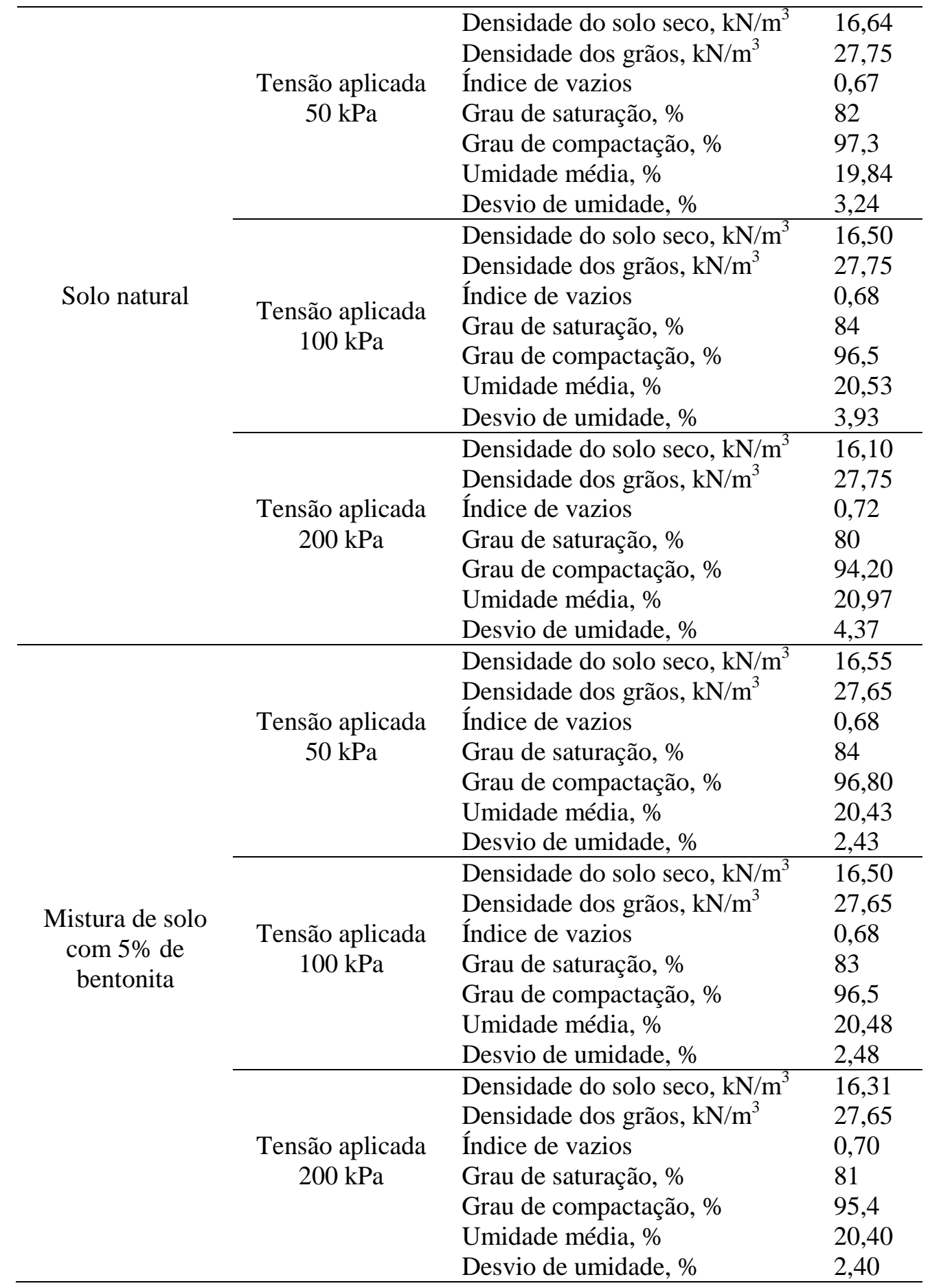




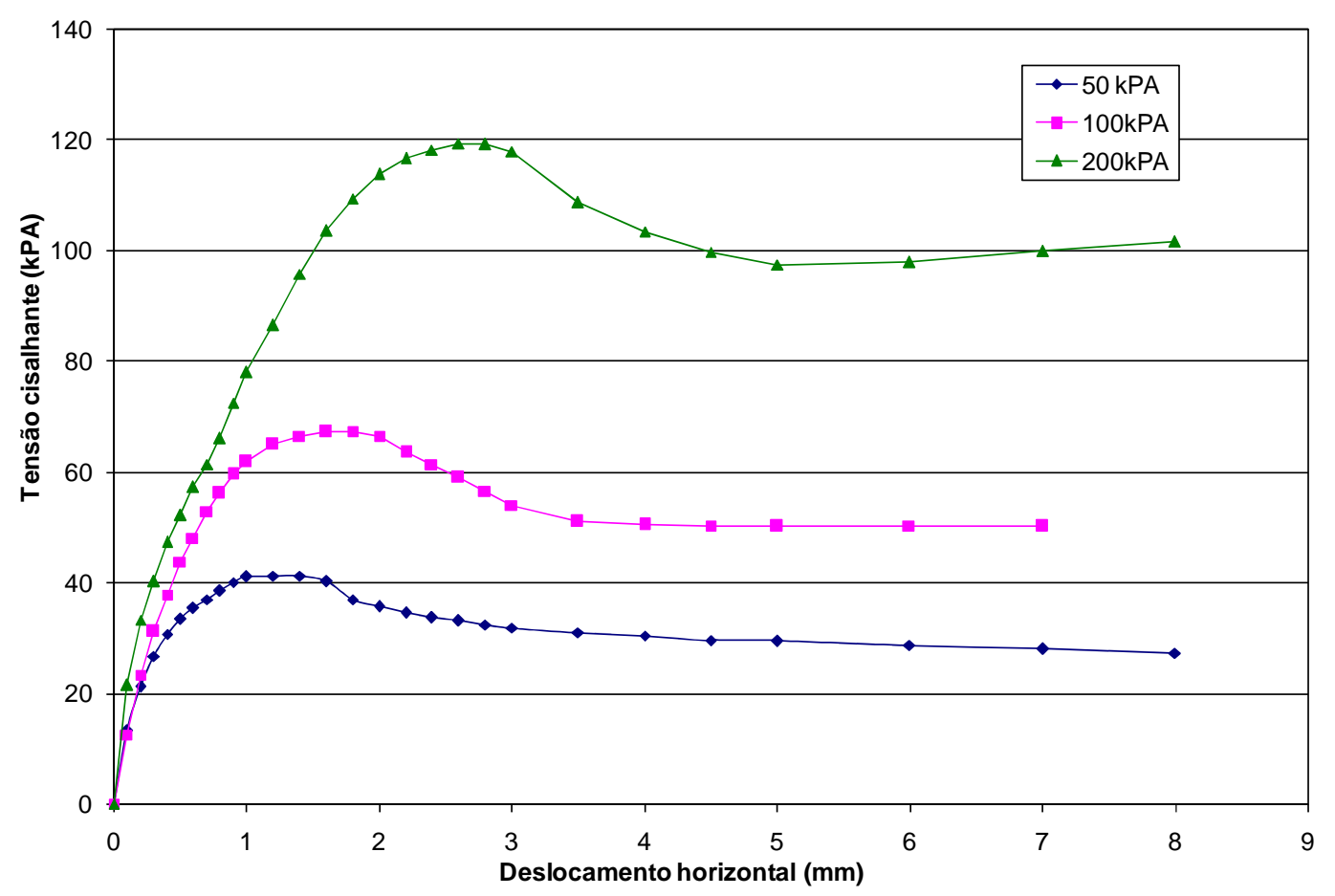

(a)

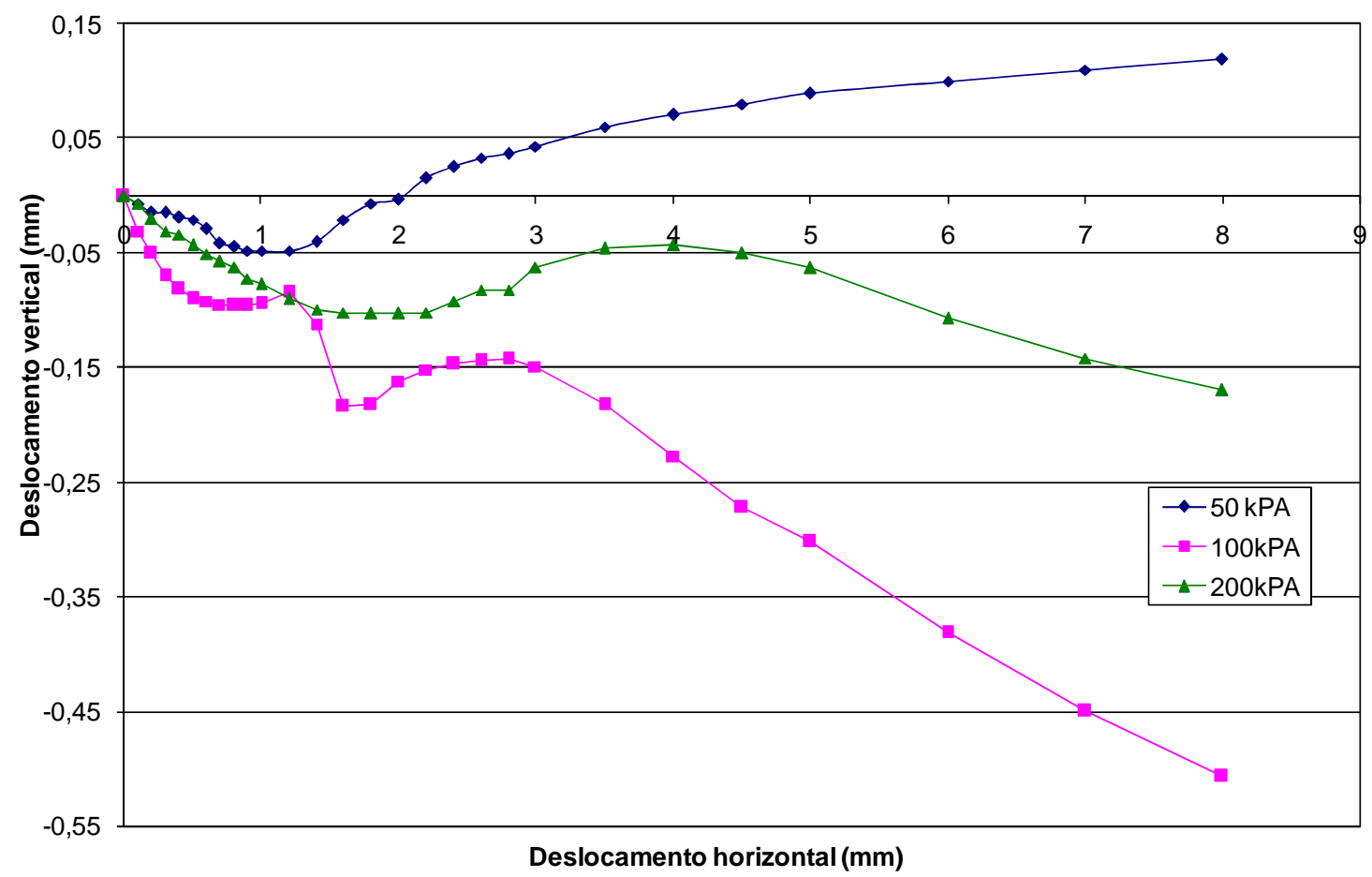

(b)

Figura 5.25 Resultados dos ensaios de cisalhamento direto com o solo natural inundado com lixiviado: (a) tensão cisalhante em função do deslocamento horizontal; (b) deslocamento vertical em função do deslocamento horizontal.

Observação: Houve erro na leitura dos deslocamentos verticais para a tensão normal de 100 kPa. 


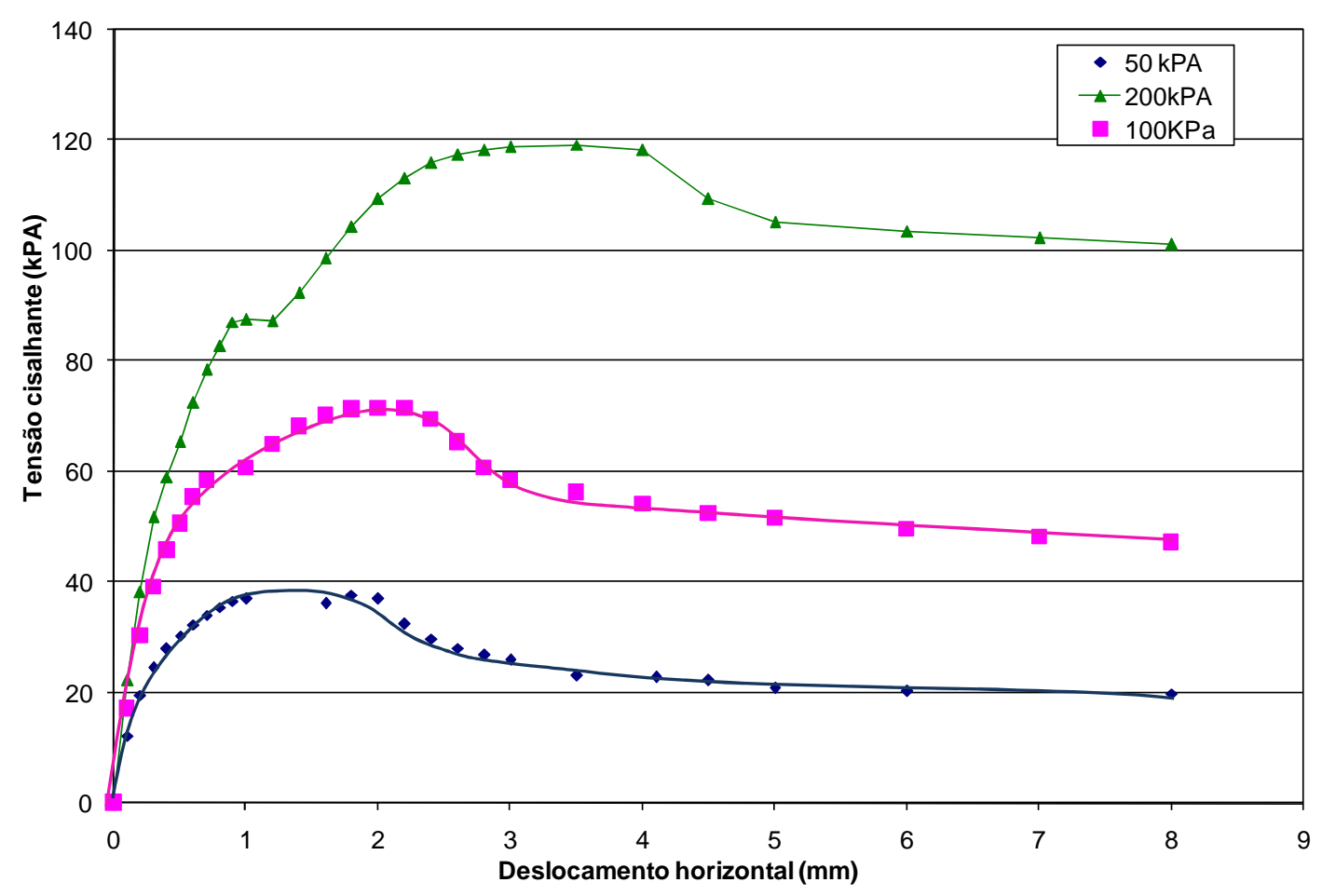

(a)

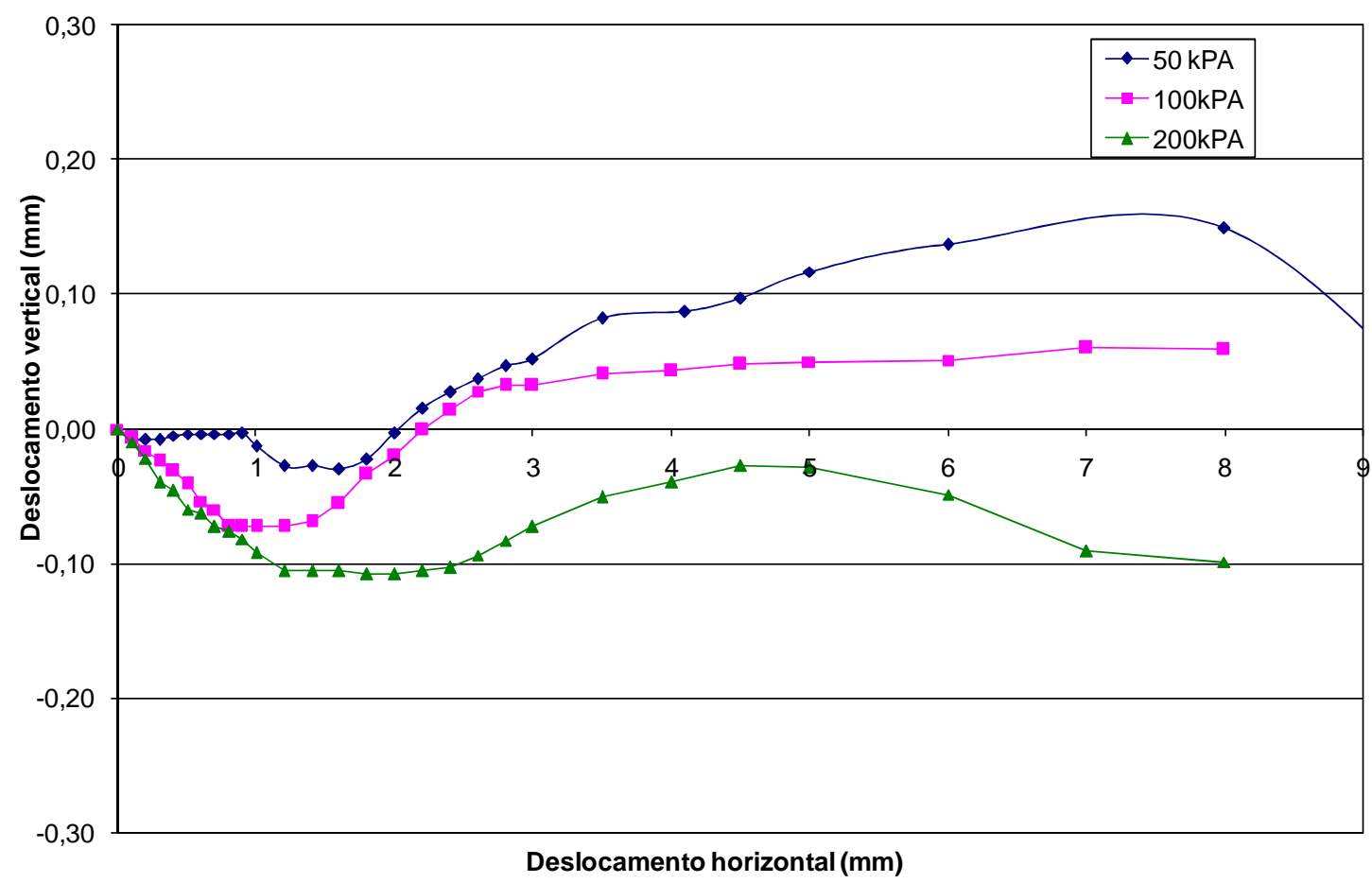

(b)

Figura 5.26 Resultados dos ensaios de cisalhamento direto do solo com a mistura de 5\% de bentonita inundado com lixiviado: (a) tensão cisalhante em função do deslocamento horizontal; (b) deslocamento vertical em função do deslocamento horizontal. 


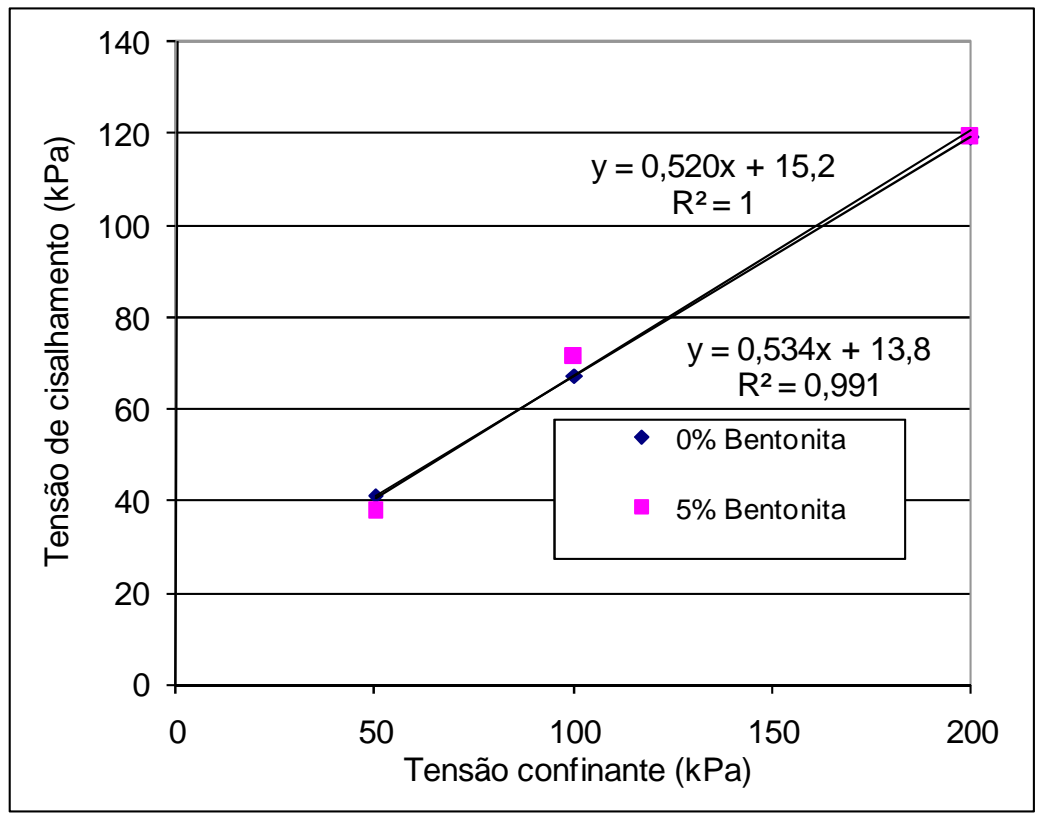

Figura 5.27 Envoltórias de resistência - inundação com lixiviado.

Tabela 5.13 Envoltórias de resistência - inundação com lixiviado.

\begin{tabular}{cccc}
\hline Material & $\boldsymbol{\sigma}\left(\mathbf{k N} / \mathbf{m}^{2}\right)$ & $\boldsymbol{\tau}_{\text {max }}\left(\mathbf{k N} / \mathbf{m}^{2}\right)$ & Resistência ao Cisalhamento \\
\hline \multirow{2}{*}{ Solo Natural } & 50 & 41,2 & $\mathrm{~s}=15,2+\sigma \operatorname{tg} 27,5^{\circ}(\mathrm{kPa})$ \\
& 100 & 67,3 & \\
\hline \multirow{2}{*}{ Solo contendo 5\% } & 500 & 119,3 & $\mathrm{~s}=13,8+\sigma \operatorname{tg} 28,1^{\circ}(\mathrm{kPa})$ \\
Bentonita & 100 & 37.7 & \\
& 200 & 71.5 & \\
\hline
\end{tabular}

A envoltória de cisalhamento do solo natural inundado com lixiviado mostra uma coesão de $15,2 \mathrm{kPa}$ e ângulo de atrito de $27,5^{\circ}$, enquanto inundado com água a coesão era de 9,9 kPa e o ângulo de atrito de $32,2 \mathrm{kPa}$, ou seja um aumento de $53 \%$ na coesão e um decréscimo de $15 \%$ no ângulo de atrito. O solo com $5 \%$ de bentonita apresentou um decréscimo de $12 \%$ da coesão (de $15,7 \mathrm{kPa}$ para $13,8 \mathrm{kPa}$ ) e de $4 \%$ do ângulo de atrito $\left(29,2^{\circ}\right.$ para $\left.28,1^{\circ}\right)$. Para a faixa de tensões estudas estas diferenças são pouco significativas, como se pode observar na Figura 5.28. Do que se pode observar, o acréscimo de bentonita e a percolação com lixiviado não alteraram significativamente a resistência do solo. 


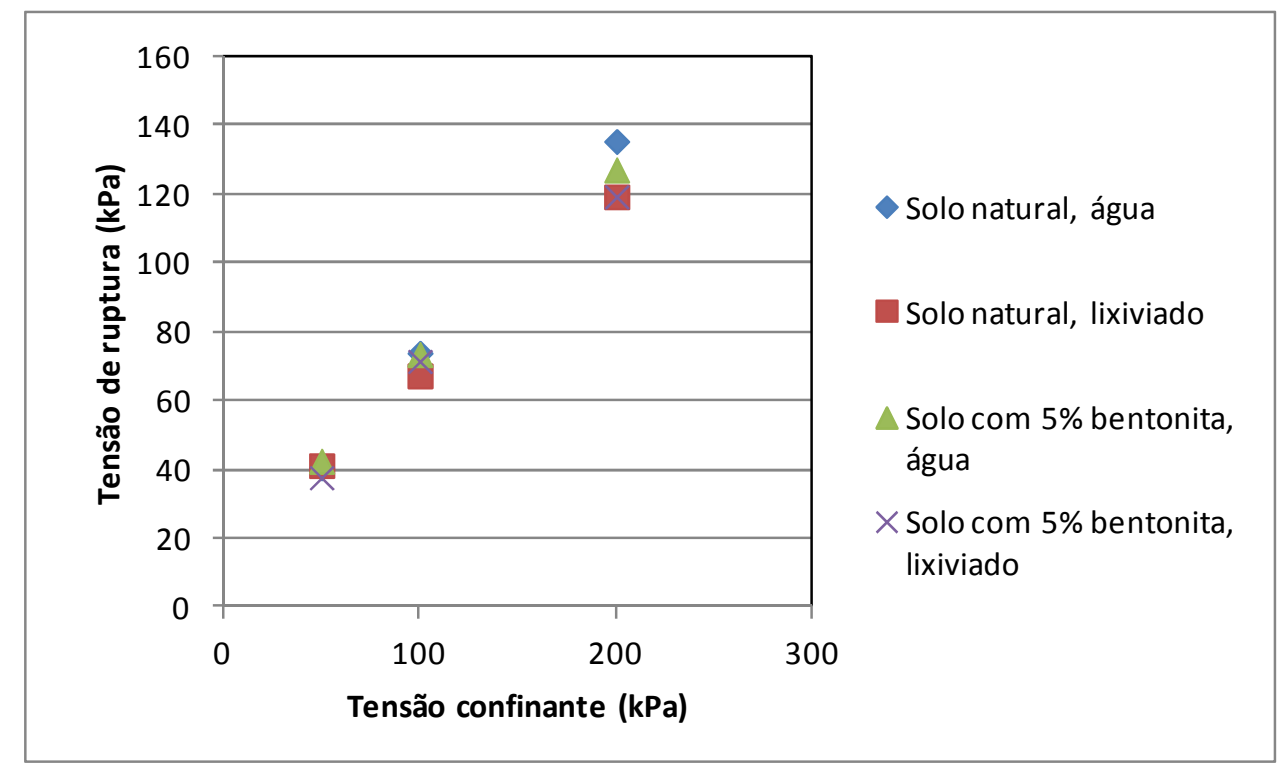

Figura 5.28 Tensões cisalhantes de ruptura para o solo natural e para a mistura de solo com $5 \%$ de bentonita, inundados com água e lixiviado.

\subsection{ENSAIO DE EXPANSÃO}

Os ensaios foram realizados com amostras de solo e com misturas de solo e bentonita com teor de $5 \%$ em peso seco, compactadas na energia modificada, no ramo úmido, utilizando-se como líquidos de inundação água e lixiviado. Os dados de moldagem dos corpos-de-prova para a realização dos ensaios, com água e com lixiviado, são apresentados, respectivamente, na Tabela 5.14 e na Tabela 5.15.

Tabela 5.14 Dados de moldagem dos corpos-de-prova dos ensaios de expansão realizados com água.

\begin{tabular}{|c|c|c|c|c|c|c|}
\hline & \multicolumn{3}{|c|}{ Solo natural } & \multicolumn{3}{|c|}{ Mistura com 5\% de bentonita } \\
\hline & $\mathbf{A}$ & B & $\mathbf{C}$ & $\mathbf{A}$ & B & $\mathbf{C}$ \\
\hline Umidade, $\%$ & 20,41 & 19,08 & 19,42 & 20,89 & 20,46 & 19,90 \\
\hline Densidade seca, $\mathrm{g} / \mathrm{cm}^{3}$ & 1,663 & 1,696 & 1,698 & 1,644 & 1,661 & 1,703 \\
\hline Índice de vazios & 0,65 & 0,62 & 0,62 & 0,68 & 0,66 & 0,62 \\
\hline Porosidade, $\%$ & 0,39 & 0,68 & 0,38 & 0,41 & 0,40 & 0,38 \\
\hline Grau de saturação, \% & 86 & 85 & 86 & 85 & 85 & 88 \\
\hline Densidade dos grãos, $\mathrm{g} / \mathrm{cm}^{3}$ & 2,746 & 2,746 & 2,746 & 2,765 & 2,765 & 2,765 \\
\hline Grau de compactação & 94,80 & 96,7 & 96,8 & 92,7 & 93,6 & 96,0 \\
\hline Desvio de umidade, $\%$ & 3,80 & 2,5 & 2,8 & 3,7 & 3,3 & 2,7 \\
\hline
\end{tabular}


Tabela 5.15 Dados de moldagem dos corpos-de-prova dos ensaios de expansão realizados com lixiviado.

\begin{tabular}{lcccccc}
\cline { 2 - 7 } & \multicolumn{3}{c}{ Solo natural } & \multicolumn{3}{c}{ Mistura com 5\% de bentonita } \\
\cline { 2 - 7 } & $\mathbf{A}$ & $\mathbf{B}$ & $\mathbf{C}$ & $\mathbf{A}$ & $\mathbf{B}$ & $\mathbf{C}$ \\
\hline Umidade, \% & 19,86 & 19,39 & 19,54 & 21,75 & 20,91 & 21,12 \\
Densidade seca, g/cm3 & 1,635 & 1,669 & 1,701 & 1,734 & 1,785 & 1,791 \\
Índice de vazios & 0,68 & 0,65 & 0,61 & 0,59 & 0,55 & 0,54 \\
Porosidade, \% & 0,40 & 0,39 & 0,38 & 0,41 & 0,35 & 0,35 \\
Grau de saturação, \% & 80 & 83 & 87 & $\sim 100$ & $\sim 100$ & $\sim 100$ \\
Densidade dos grãos, g/cm3 & 2,746 & 2,746 & 2,746 & 2,765 & 2,765 & 2,765 \\
Grau de compactação & 93,2 & 95,5 & 97,3 & 97,8 & $\sim 100$ & $\sim 100$ \\
Desvio de umidade, \% & 3,3 & 2,8 & 2,9 & 4,5 & 3,7 & 3,9 \\
\hline
\end{tabular}

A Figura 5.29 exemplifica a expansão livre dos corpos-de-prova após a retirada da carga total; no caso, foram três corpos-de-prova de solo natural, tendo sido utilizada água na inundação. Os resultados dos ensaios realizados com solo natural e mistura com 5\% de bentonita, inundados com água e lixiviado, estão apresentados na Tabela 5.16 e na Tabela 5.17. A Tabela 5.18 demonstra os valores médios de expansão do silte natural e da mistura com 5\% de bentonita, na presença de água e de lixiviado.

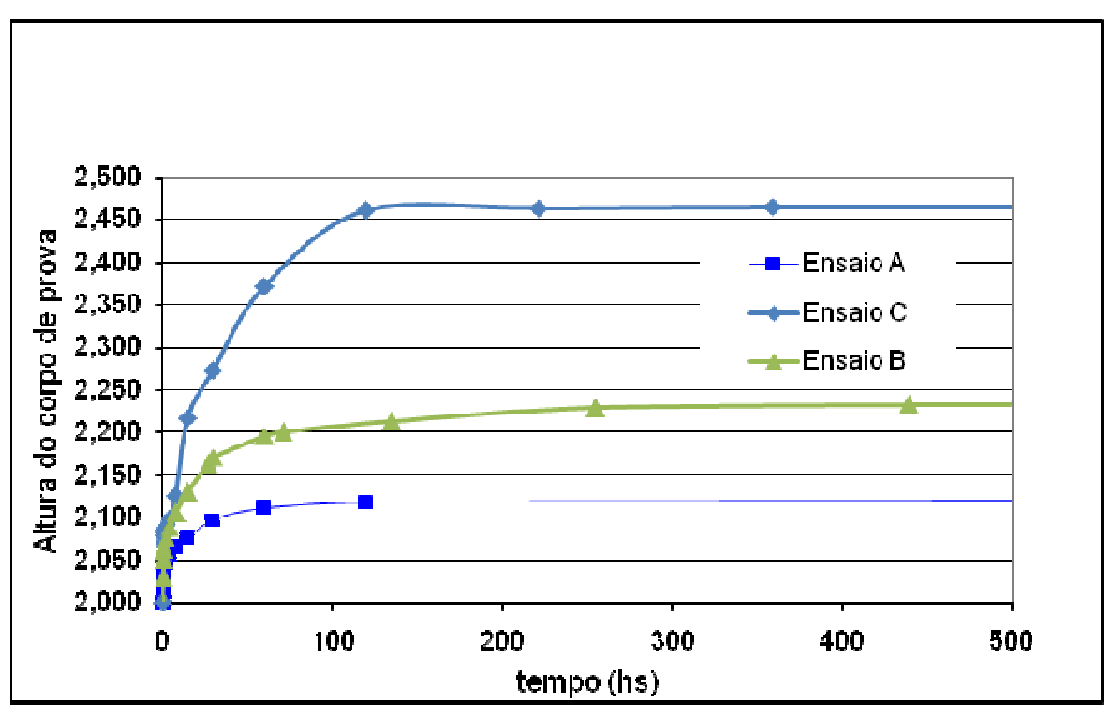

Figura 5.29 Exemplo de expansão livre dos corpos-de-prova após a retirada da carga total ensaios com solo natural inundado com água. 
Tabela 5.16 Resultados dos ensaios de expansão das amostras inundadas com água.

\begin{tabular}{lcccccc}
\cline { 2 - 7 } & \multicolumn{3}{c}{ Solo natural } & \multicolumn{3}{c}{ Mistura com 5\% de bentonita } \\
\cline { 2 - 7 } & A & B & C & A & B & C \\
\hline Pressão de expansão $\left(\mathrm{kN} / \mathrm{m}^{2}\right)$ & 21 & 24 & 16 & 26 & 40 & 35 \\
Expansão (cm)* & 0,14 & 0,30 & 0,49 & 0,39 & 0,39 & 0,46 \\
\% de expansão & 7 & 15 & 24 & 20 & 20 & 23 \\
\hline
\end{tabular}

*expansão após o descarregamento

Tabela 5.17 Resultados dos ensaios de expansão das amostras inundadas com lixiviado.

\begin{tabular}{lcccccc}
\cline { 2 - 7 } & \multicolumn{3}{c}{ Solo natural } & \multicolumn{3}{c}{ Mistura com 5\% de bentonita } \\
\cline { 2 - 7 } & A & B & C & A & B & C \\
\hline Pressão de expansão $\left(\mathrm{kN} / \mathrm{m}^{2}\right)$ & 21 & 26 & 23 & 17 & 20 & 16 \\
Expansão $(\mathrm{cm}) *$ & 0,19 & 0,19 & 0,19 & 0,09 & 011 & 012 \\
\% de expansão & 9 & 9 & 10 & 5 & 5 & 6 \\
\hline
\end{tabular}

*expansão após o descarregamento

Tabela 5.18 Resultados médios dos ensaios de expansão.

\begin{tabular}{lllll}
\hline \multirow{2}{*}{ Propriedades } & \multicolumn{2}{c}{ Solo natural } & \multicolumn{2}{c}{ Mistura com 5\% de bentonita } \\
\cline { 2 - 5 } & Água & Lixiviado & Água & Lixiviado \\
\hline Pressão de expansão $\left(\mathrm{kN} / \mathrm{m}^{2}\right)$ & 20 & 23 & 34 & 18 \\
Expansão $(\mathrm{cm})^{*}$ & 0,31 & 0,19 & 0,41 & 0,16 \\
\% de expansão & 15 & 9 & 21 & 5 \\
\hline
\end{tabular}

*expansão após o descarregamento

O solo natural é expansivo, apresentando em média 15\% de expansão livre, porém apresenta baixa pressão de expansão $\left(20 \mathrm{kN} / \mathrm{m}^{2}\right)$ quando na presença de água. Ao se adicionar $5 \%$ de bentonita, ocorre um aumento da média de expansão livre, que passa a $21 \%$, ocorrendo também um aumento de pressão de expansão $\left(34 \mathrm{kN} / \mathrm{m}^{2}\right)$.

Com o lixiviado a porcentagem média da expansão livre do solo natural passa a ser de $9 \%$, com a pressão de expansão de $23 \mathrm{kN} / \mathrm{m}^{2}$. Para a mistura com $5 \%$ de bentonita, a inundação com lixiviado reduz a porcentagem média de expansão livre para 5\% e a pressão de expansão 
para $18 \mathrm{kN} / \mathrm{m}^{2}$. A diminuição da expansão com o lixiviado pode ser devida à adsorção de espécies químicas presentes no lixiviado pelo solo e pela bentonita.

A Tabela 5.19 apresenta os critérios de expansão de Seed et al. (1962) para amostras compactadas segundo análise de Sandroni e Consoli (2010). O potencial de expansão (intensidade com que um solo pode expandir) foi obtido sob carga de $7 \mathrm{kPa}$. Segundo esses critérios, o solo estudado e a mistura de solo com $5 \%$ de bentonita são classificados como de alta expansão (expansão de $15 \%$ e $21 \%$, respectivamente, para inundação com água). Deve-se lembrar, porém, que os valores de expansão nesta investigação foram obtidos com descarregamento total do corpo-de-prova; como a pressão de expansão é baixa, sob $7 \mathrm{kPa}$ talvez resultasse uma expansão menor.

Tabela 5.19 Critérios de expansão de Seed et. al (1962) e Van der Merwe (1964) apud Sandroni e Consoli (2010).

\begin{tabular}{lc}
\hline Categoria de Expansão & Expansão (\%) \\
\cline { 2 - 2 } Baixa & Seed et al. (1962) \\
Média & $<1,5$ \\
Alta & 1,5 a 5 \\
Muito Alta & 5 a 25 \\
\hline
\end{tabular}

A inundação com lixiviado resulta em expansão inferior à inundação com água, porém ainda dentro da faixa de alta expansão de Seed et al. (1962): 9\% e 5\% para, respectivamente, o solo e a mistura de solo com 5\% de bentonita. Sandroni e Consoli (2010) lembram que os estudos de expansão não devem ter sua conclusão baseada apenas nos ensaios de caracterização, que só refletem a tendência de expansão que emana da mineralogia e da granulometria do solo; o potencial de expansão depende também da umidade e sucção iniciais do solo, e da condição da amostra (indeformada ou compactada). Este estudo mostra que o líquido de inundação também influi na expansão do solo, o que deve ser investigado em aplicações geotécnicas que envolvam soluções contaminantes. 


\section{CONCLUSÕES}

Nesta pesquisa investigou-se a viabilidade de se utilizar um solo saprolítico de filito, um silte arenoso de grande ocorrência na Região Metropolitana de São Paulo, como material de impermeabilização de fundo de aterro sanitário. O solo, classificado como ML (silte de baixa compressibilidade), é composto predominantemente por quartzo e mica (muscovita), tem $\mathrm{pH}$ de 5,1 e 4,1 em $\mathrm{H}_{2} \mathrm{O}$ e $\mathrm{KCL}$, respectivamente, e capacidade de troca cationnica a pH 7 de 1,64 $\mathrm{cmolc} / \mathrm{kg}$.

O solo saprolítico de filito compactado no ponto ótimo ou no ramo úmido na energia normal apresenta coeficiente de permeabilidade à água de cerca de $5 \times 10^{-8} \mathrm{~m} / \mathrm{s}$, superior ao limite máximo de $10^{-9} \mathrm{~m} / \mathrm{s}$, estipulado pela maioria das normas ambientais para as camadas de revestimentos de fundo de aterro de resíduos sólidos ("liners”). Apenas o aumento da energia de compactação (para a energia modificada) não diminui suficientemente o coeficiente de permeabilidade do solo, tampouco o acréscimo de $5 \%$ de bentonita com compactação na energia normal. Por outro lado, um teor de $5 \%$ de bentonita adicionado ao solo compactado na energia modificada é suficiente para atender às exigências das normas de impermeabilização de aterro sanitário, resultando em um coeficiente de permeabilidade à água de $6 \times 10^{-10} \mathrm{~m} / \mathrm{s}$.

Ensaios de permeabilidade ao lixiviado de aterro sanitário com o solo natural e com mistura de solo com $5 \%$ de bentonita compactados na energia modificada mostraram que a percolação de lixiviado causa uma redução no coeficiente de permeabilidade, que tende a $3 \times 10^{-10} \mathrm{~m} / \mathrm{s}$ para os dois materiais, o que representa uma redução de duas vezes em relação à permeabilidade à água para a mistura e de 100 vezes para o solo.

Tendo sido atendido o critério de permeabilidade, pesquisou-se se a adição de bentonita alterava a resistência e a deformabilidade do solo, uma vez que os solos saprolíticos de filito são reconhecidamente expansivos na presença de água, tanto em condição indeformada como compactados. Direcionou-se então a pesquisa para a investigação da resistência ao cisalhamento, compressibilidade em ensaio de adensamento edométrico e expansão, para o solo natural e mistura com 5\% de bentonita, compactados na energia modificada, com água e com lixiviado de aterro sanitário como fluidos de inundação. 
Os ensaios de adensamento mostraram que o solo natural compactado na energia modificada é pouco compressível. O índice de compressão é 0,122 e o índice de expansão, 0,058. A adição de 5\% de bentonita aumenta o índice de compressão em 35\% e o índice de expansão em 19\%. Na presença de lixiviado, os índices de compressão e de expansão do solo natural compactado foram, respectivamente, $19 \%$ e $28 \%$ maiores do que com água, e os da mistura de solo com $5 \%$ de bentonita, respectivamente, $16 \%$ e $3 \%$ maiores do que com água. O efeito da adição de bentonita e do contato com o lixiviado, apesar de aumentar percentualmente a compressibilidade, ainda assim está dentro de valores de baixa compressibilidade.

Os ensaios de cisalhamento direto mostraram que o solo natural compactado na energia modificada tem boa resistência, apresentando certa coesão (10kPa) e um ângulo de atrito de $32^{\circ}$, dentro da faixa de valores para argilas com IP semelhante. A adição de bentonita eleva a coesão de $59 \%$ e diminui o ângulo de atrito de $9 \%$, não causando grande modificação na envoltória de resistência para a faixa de tensões estudada. Quando o líquido de inundação foi o lixiviado, houve um aumento de $53 \%$ na coesão e um decréscimo de $15 \%$ no ângulo de atrito para o solo natural; já para a mistura com $5 \%$ de bentonita houve um decréscimo de $12 \%$ da coesão e de $4 \%$ do ângulo de atrito. Pode-se observar, assim, que para a faixa de tensões estudadas nem o acréscimo de bentonita, tampouco a percolação com lixiviado, alteraram significativamente as características de resistência do solo.

O solo natural compactado na energia modificada é expansivo, com 15\% de expansão livre em média, porém apresenta baixa pressão de expansão $\left(20 \mathrm{kN} / \mathrm{m}^{2}\right)$ quando na presença de água. Ao se adicionar 5\% de bentonita, ocorrem um aumento da expansão livre, que passa a $21 \%$, e também um aumento da pressão de expansão $\left(34 \mathrm{kN} / \mathrm{m}^{2}\right)$. Com o lixiviado, a expansão livre diminui para $9 \%$ e a pressão de expansão aumenta ligeiramente para $23 \mathrm{kN} / \mathrm{m}^{2}$ para o solo natural. A expansão livre reduz para $5 \%$ e a pressão de expansão, para $18 \mathrm{kN} / \mathrm{m}^{2}$, quando a mistura de solo com $5 \%$ de bentonita é ensaiada com lixiviado. Observa-se, assim, que o efeito da adição de bentonita e do contato com o lixiviado não altera significativamente a expansibilidade do material.

Pode-se concluir que a adição de $5 \%$ de bentonita ao solo saprolítico de filito, com umidade próxima à umidade ótima e a compactação na energia modificada, resulta em uma diminuição da permeabilidade suficiente para atender aos requisitos de "liners", acompanhada de pequena 
alteração na resistência (aumento da coesão e redução do ângulo de atrito, mas gerando envoltórias de resistência praticamente coincidentes na faixa de tensões estudadas) e ligeiro aumento da compressibilidade e da expansão. Portanto, o material torna-se adequado em termos de permeabilidade sem que sejam alteradas significativamente suas demais propriedades geotécnicas.

A percolação de lixiviado pelo solo natural e pela mistura do solo com $5 \%$ de bentonita, compactados na energia modificada, causa uma redução do coeficiente de permeabilidade para $3 \times 10^{-10} \mathrm{~m} / \mathrm{s}$, um aumento pouco significativo na compressibilidade, uma redução na expansão e uma pequena alteração nos parâmetros de resistência, a qual praticamente não altera as envoltórias de resistência na faixa de tensões estudadas. Pode-se concluir que os dois materiais são compatíveis com o lixiviado.

Tendo em vista os resultados obtidos, a mistura de solo saprolítico de filito com $5 \%$ de bentonita compactada na energia modificada é um material adequado para a construção de revestimentos de fundo de aterros sanitários. 


\section{PROSSEGUIMENTO DA PESQUISA}

Entende-se que o objetivo da pesquisa foi alcançado, no que se refere à avaliação das características geomecânicas do material de estudo (mistura de silte com 5\% de bentonita) para o uso como impermeabilização de base de aterro sanitário.

Como prosseguimento de pesquisa, sugere-se que seja realizada investigação sobre o comportamento geoambiental do material para o uso a que se propõe, ou seja, a avaliação da retenção de poluentes e da atenuação natural do lixiviado pela base impermeabilizante do aterro, caso ocorra algum sinistro. Para tal, podem ser realizados ensaios de coluna e análise da microestrutura do material estudado.

É importante aprofundar o estudo da permeabilidade e da retenção de poluentes investigandose o efeito do gradiente hidráulico.

A pesquisa poderia ser repetida para outros teores de bentonita, por exemplo, 2,5\% e 7,5\%, para verificar a tendência da alteração no comportamento geomecânico do solo em função do teor de bentonita.

Sugere-se também investigar a relação da expansão com a adsorção de espécies químicas presentes no percolado.

Por fim, é interessante investigar a viabilidade econômica da utilização das misturas solobentonita no revestimento de fundo de aterros sanitários, assim como estudar aspectos operacionais relativos à implantação da obra. 


\section{BIBLIOGRAFIA}

ABREU, R.C. (2000). Compressibilidade de maciços - Tese de Mestrado, 241p. Escola Politécnica da Universidade de São Paulo.

ALONSO, R.U. (1999). Rebaixamento temporário de aquíferos. Tecnogeo/Geofix, gráfica Lamara, São Paulo, 131p.

ARAÚJO, A.S.F.; CASTRO, J.A.; SILVA, A.J.; RITTER, E.(2007). Modelagem do fenômeno de transferência de massa do íon cálcio do lixiviado para o solo de aterros. IV Congresso Brasileiro de Geotecnia Ambiental-REGEO, CDRom, 7p., Pernambuco, Brasil.

ASSOCIAÇÃO BRASILEIRA DE NORMAS TÉCNICAS. NBR 6.459: Determinação do limite de liquidez. 1984. 6p.

NBR 6.502: Rochas e solos - Terminologia. 1985. 18p.

NBR 6.508: Determinação da massa específica de grãos de solo - Método de ensaio. 1982.9p.

. NBR 7.180: Determinação do limite de plasticidade. 1984. 3p.

NBR 7.181: Análise granulométrica. 1984. 13p.

NBR 7.182: Ensaio de compactação. 1986. 10p.

NBR 8.419: Apresentação de projetos de aterro sanitário de resíduos sólidos urbanos. 1992. $7 p$.

NBR 10.004: Resíduos sólidos. 2004. 63p.

NBR 12.007: Ensaio de adensamento unidimensional. 1990. 13p 
AMERICAN SOCIETY FOR TESTING MATERIALS - ASTM D 5084-03. Standard Test Methods for Measurement of Hydraulic Conductivity of Saturated Porous Materials Using a Flexible Wall Permeameter. 2003.

ASTM D 5819. Standard Guide for Selecting Test Methods for Experimental Evaluation of Geosynthetic Durability. 1999.

AURINKO, H.; KUJALA, K. (2005). Comparision of mineral liners used in landfill construction. Sardinia 2005-Tenth International Waste Management and Landfill Symposium, Proceedings, CDRom, 8p., S. Margherita di Pula, Itália.

BASSANI, F.; FRANCO, J.M.; BOLZANI, H.R.; CASTRO, T.M.; MARTINS L.F.V.; CORNELI, V.M.; TAVARES, C.R.G.; LAUTENSCHLAGER, S.R. (2009). Destinação final dos resíduos sólidos urbanos: Diagnóstico do município de Maringá/Paraná.I International Congress ond Subsurface Environment-CIMAS, CDRom, 10p., São Paulo, Brasil.

BENTONIT União Nordeste Ind. e Com. Ltda (2009). Disponível em http://www.bentonit.com.br/oque_sao.asp, acesso em 05.11.09

BOSCOV, M. E. G. (1997). Contribuição ao projeto de contenção de resíduos perigosos utilizando solos lateríticos - Tese de Doutorado, Escola Politécnica da Universidade de São Paulo.

BOSCOV, M.E.G.; ABREU, R.C. (2000). Aterros Sanitários. Previsão de desempenho x Comportamento real, 37p., ABMS, São Paulo

BOSCOV, M. E. G. (2005). Texto de sistematização crítica de parte da obra da candidata, apresentado ao departamento de engenharia de estruturas e fundações da EPUSP Concurso de livre-docência, Escola Politécnica da Universidade de São Paulo.

BOSCOV, M. E. G. (2008). Geotecnia Ambiental. Ed. Oficina de Textos, 248p. 
BOWLES, J. E. (1977). Foundations Analysis and Design. MacGraw-Hill Book Co., 2th Edition, New York.

BRASIL.Constituição (1988). Constituição da República Federativa do Brasil. Brasília, DF: Senado, 1988

BROLLO, M.J. (2001). Metodologia automatizada para seleção de áreas para disposição de resíduos sólidos. Aplicação na região Metropolitana da Campinas (SP). Tese de Doutorado, 233p. Faculdade de Saúde Pública da USP.

BUENO, B.S. (2003). Propriedades, especificações e ensaios. IV Simpósio Brasileiro de Geossintéticos, V Congresso Brasileiro de Geotecnia Ambiental-REGEO 2003, Anais, volume único, pp.163-176, Porto Alegre.

CARVALHO, J.C.; SALES, M.M.; SOUZA, N.M.; MELO, M.T.S. (2006). Processos Erosivos no Centro-Oeste Brasileiro. Editora FINATEC, 108p. Brasília.

CARVALHO, M.F. (1999). Comportamento mecânico de resíduos sólidos urbanos. Tese de doutorado, 278p. Escola de Engenharia de São Carlos, São Paulo

CETESB - COMPANHIA AMBIENTAL DO ESTADO DE SÃO PAULO (1993). Resíduos sólidos industriais, 2ed. rev. ampl., São Paulo.

CETESB - COMPANHIA AMBIENTAL DO ESTADO DE SÃO PAULO (1999). Apostila de aterro sanitário, 2ed. rev. ampl., São Paulo.

CETESB - COMPANHIA AMBIENTAL DO ESTADO DE SÃO PAULO (2008). Inventário Estadual de Resíduos Sólidos Domiciliares. Série Relatórios.

CETESB - COMPANHIA AMBIENTAL DO ESTADO DE SÃO PAULO (2010). Inventário Estadual de Resíduos Sólidos Domiciliares 2009. Série Relatórios. 
COMMITTEE ON TROPICAL SOILS OF THE ISSMFE (1985). Peculiarities of geotechnical behavior of tropical lateritic and saprolitic soils-progress report. ABMS

CONCIANI, W. (2006). Fundações para construção de Habitação de Interesse Social no Estado de Mato Grosso. Ed. CEFETMT, primeira edição, 78p.

CONSELHO NACIONAL DO MEIO AMBIENTE. CONAMA n 5 (1993) - Dispõe sobre o gerenciamento de resíduos sólidos gerados nos portos, aeroportos, terminais ferroviários e rodoviários, $4 \mathrm{p}$.

CONAMA no 307 (2002) - Estabelece diretrizes, critérios e procedimentos para a gestão dos resíduos da construção civil, $4 \mathrm{p}$.

CONAMA no 358 (2005) - Dispõe sobre o tratamento e a disposição final dos resíduos dos serviços de saúde e dá outras providências, $8 \mathrm{p}$.

CONTI, L.; NETTUNO, L. (2005). Design and construction of landfills barrier systems: performance criteria and equivalence levels. Sardinia 2005-Tenth International Waste Management and Landfill Symposium, Proceedings, CDRom, 7p., S. Margherita di Pula, Itália.

CRUZ, P.T. (1987). Solos residuais: algumas hipóteses de formulações teóricas de comportamento. Seminário em geotecnia de solos tropicais. Brasília, 33p.

CRUZ, P.T. (1996). 100 Barragens Brasileiras: Casos históricos, materiais de construção, projeto. Ed. Oficina de Textos, São Paulo, 647p.

DEPARTAMENTO NACIONAL DE PRODUÇÃO MINERAL. DNPM - (2006). Sumário Mineral.

- DNPM - (2009). Bentonita. Disponível em http://www.dnpm.gov.br/assets/galeriadocumento/sumariomineral2004/BENTONITA\%2020 04.pdf, 10.07.2009. 
DOURADO, A.K. (2003). Condutividade hidráulica de materiais de baixa permeabilidade: Desenvolvimento, construção e teste de um sistema de medida. Dissertação de mestrado, 96 p. Escola Politécnica da USP, São Paulo.

EMPRESA BRASILEIRA DE PESQUISA AGROPECUÁRIA - EMBRAPA (1997). Manual de métodos de análise de solos. 2 ed.. Rio de Janeiro, 212p.

EMPRESA BRASILEIRA DE PESQUISA AGROPECUÁRIA - EMBRAPA (1999). Sistema brasileiro de classificação de solos. Brasília, 412p.

EMPRESA BRASILEIRA DE PESQUISA AGROPECUÁRIA - EMBRAPA (1999). Manual de análises químicas de solos, plantas e fertilizantes. Brasília, 370p.

ESSENCIS SOLUÇÔES AMBIENTAIS (2009). Disponível em http://www.essencis.com.br/unidades/essencis-sp, acesso em 09.11.09

ESTADO DE SÃO PAULO (2009). Disponível em http://portal.prefeitura.sp.gov.br/secretarias/servicoseobras/servicos/0011), /09.

FERRARI, A.A.P (2005). Viabilidade da utilização de silte compactado como material de impermeabilização em aterros de resíduos. Dissertação de mestrado, 118 p. Escola Politécnica da USP, São Paulo.

FRANCISCA, F.M.; GLATSTEIN, D.A. (2010). Long term hydraulic conductivity of compacted soil permeated with landfill leachate. Journal Applied Clay Science vol. 49, 7p.

FRANÇA, F.F.; DOURADO, A.K; VILAR, O.M. (2007). Aspectos da expansão de geocompostos bentoníticos. V Simpósio Brasileiro de Geossintéticos, CDRom, 5p, Pernambuco, Brasil.

FREMPONG, E. M. ; YANFUL, E. K. (2008). Interactions between Three Tropical Soils and Municipal Solid Waste Landfill Leachate. Journal of geotechnical and geoenvironmental engineering, vol. 134, 18 p. 
HAMADA, J.; CALÇAS, D.A.N.Q.P.; GIACHETI, H. L. (2004) - Influência da compactação de um solo arenoso na infiltração e retenção de carga orgânica de chorume. $23^{\circ}$ Congresso Brasileiro de Eng. Sanitária e Ambiental.

IBGE- Instituto Brasileiro de Geografia e Estatística (1990). Pesquisa Nacional de Saneamento Básico - PNSB, Rio de Janeiro

IBGE- Instituto Brasileiro de Geografia e Estatística (2000). Pesquisa Nacional de Saneamento Básico - PNSB, Rio de Janeiro

IPT - INSTITUTO DE PESQUISAS TECNOLÓGICAS / CEMPRE - COMPROMISSO EMPRESARIAL POR RECICLAGEM (2000). Lixo Municipal: Manual de gerenciamento integrado, $2^{\circ}$ ed., São Paulo.

ISSMGE (2005). Innovative Barriers and Barrier Materials. International Society for Soil Mechanics and Geotechnical Engineering. TC5 Task Force 3 (TF3) Report. Charles Duanne Shackelford. Craig H. Benson, Abdelmalek Bouazza, Luiz de Mello, Maria Eugenia Boscov, John Bowders, Rolf Katzenbach, Horace Moo-Yong, Tom Zimmie and Jorge Zornberg. CDROM.

IWAI, C.K. (2005). Tratamento de chorume através de percolação em solos empregados como material de cobertura de aterros para resíduos sólidos urbanos. Dissertação de mestrado, 205 p. Faculdade de Engenharia da UNESP - Bauru, São Paulo.

KENNEY, T.C.; Van Veen, W.A.; SWALlOW, M. A.; SUNGAILA, M. A.. (1992). Hydraulic conductivity of compacted bentonite-sand mixtures. Canadian Geotechnical Journal, Vol. 29, 11p.

KNOPP, A.; CONSOLI, N.C.; HEINECK, K. S.; THOMÉ, A.; VANGULCK, J. (2007). Efeitos da percolação de águas ácidas na compressibilidade de um liner. IV Congresso Brasileiro de Geotecnia Ambiental-REGEO, CDRom, Pernambuco, Brasil.

LAMBE, T.W.; WHITMAN, R.V. (1969). Soil mechanics. New York: John Wiley \& Sons, USA. 1979. 553p. 
LAESPIGA, M.A.M. (2008). Transporte de solutos em barreiras de material argiloso compactado (CCL) e geocomposto bentonítico (GCL): fluxos diretos, acoplados e comportamento membrana. Tese de doutorado, 218 p. Escola de Engenharia de São Carlos da Universidade de São Paulo, São Paulo.

LEPSCH, I.F. (2002). Formação e conservação dos solos. Ed. Oficina de Textos, primeira edição, 178p.

LUKIANTCHUKI, J.A.; ESQUIVEL, E.R. (2007). Influência do teor de bentonita na condutividade hidráulica e na resistência ao cisalhamento de solos arenosos. IV Congresso Brasileiro de Geotecnia Ambiental-REGEO, CDRom, 8p., Pernambuco, Brasil.

LUKIANTCHUKI, J.A.(2007). Influencia do teor de bentonita na condutividade hidráulica e na resistência ao cisalhamento em um solo arenoso utilizado como barreira impermeabilizante. Dissertação de mestrado, 124p. Escola de Engenharia de São Carlos, São Paulo

MIZUNO, K.; ENDO, K.; HONGO,T.; FUJIWARA, T.; KAMON, M.; IWASAKI, Y. (2005).Quality control of bentonite mixed soil as clay-liner for waste landfill. Sardinia 2005-Tenth International Waste Management and Landfill Symposium, Proceedings, CDRom, 11p., S. Margherita di Pula, Itália

MONDELLI, G. (2004). Investigação geoambiental em áreas de disposição de resíduos sólidos urbanos utilizando a tecnologia do piezocone. Dissertação de mestrado, 264 p. Escola Politécnica da USP, São Paulo.

MORI, R.T. (1987). Solos saprolíticos compactados, experiência brasileira e internacional. Seminário em geotecnia de solos tropicais. Brasília, 15p.

MOURA, C.L.; HYPÒLITO, R.; PUGAS, M.S.; EZAKI, S.; NASCIMENTO, S.C.; GARCIA, M.A.A.; TANASOV, V.S.; SOTELO, A.F.. (2009). Comprometimento do meio subterrâneo pelas atividades oriundas de aterros sanitários na região de Tremembé/SP. 
I International Congress ond Subsurface Environment-CIMAS, CDRom, 15p., São Paulo, Brasil.

LINHARES, L.A.; FILHO, F.B. E.; IANHEZ, R.; SANTOS, E.A..Aplicação dos modelos de Langmuir e Freundlich na adsorção de cádmio e chumbo em diferentes classes de solos brasileiros. Revista Tecnológica, v. 17, p. 49-60, 2008.

MOURA, H.H.S.G.; GARCIA, F.J.A.Y. (1985). Influence of the silt fraction mineralogy on the behavior of saprolitic soils. First International Conference on Geomechanics in Tropical - Tropicals' 85. Brasília : ABMS, v. 2. p. 345-358.

MUSSO, M.; PEJON,O.J. (2007). Transporte de poluentes em barreiras de argilas compactadas para proteção do aqüífero Guarani. IV Congresso Brasileiro de Geotecnia Ambiental-REGEO, CDRom, 7p., Pernambuco, Brasil.

NASCENTES R. (2006). Estudo da mobilidade de metais pesados em um solo residual compactado. Tese de doutorado, 181 p. Universidade Federal de Viçosa, MG

NOGAMI, J.S.; VILLIBOR, D.F. (1995). Pavimentação de baixo custo com solos lateríticos. Ed. Vilibor, 240p.

PIMENTEL, V.E. (2008). Avaliação da resistência ao cisalhamento em GCL - Uma nova tecnologia de ensaio. Dissertação de mestrado, 160 p. Escola de Engenharia de São Carlos, São Paulo.

PINTO, C.S. (2002). Curso básico de Mecânica dos solos em 16 aulas. Ed. Oficina de Textos, segunda edição, 247p.

PINTO, C.S. (1993).Solos do interior de São Paulo. ABMS, São Paulo, 399 p.

PITANGA, H.N. (2007). Caracterização dos comportamentos hidráulicos e mecanicos de geocompostos bentoníticos e de outros sistemas geossintéticos destinados as camadas de cobertura de aterro. Tese de doutorado, 340p. Escola de Engenharia de São Carlos, São Paulo. 
QUEIROZ,P.I.B., NEGRO, A.; SILVA, B., C., P., (2008). Occupation of contaminated areas in Metropolises - The Case of Sao Paulo. Workshop internacional do TC-41, CDRom, 10p., Rio de Janeiro, Brasil

RAIJ, B. V.; ANDRADE, J.C.; CANTARELLA, H.; QUAGGIO, J.A. Análise química para avaliação da fertilidade de solos tropicais. Campinas: Instituto Agronômico, 2001. 285p.

SAADI, L.A.; COURADIN,A.; DIDIER, G. (2005). Homogeneity and hydraulic conductivity control of a tight barrier treated with bentonite. Sardinia 2005-Tenth International Waste Management and Landfill Symposium, Proceedings, CDRom, 8p., S. Margherita di Pula, Itália.

SANDRONI, S.S.; CONSOLI, N.C. (2010). Sobre a prática de engenharia geotécnica com dois solos difíceis: os extremamente moles e os expansivos, 84 p.. COBRAMSEG Congresso Brasileiro de Mecânica dos Solos e Engenharia Geotécnica, Gramado, Brasil

SCHUELER, A.S.; MAHLER, C. F. (2007). Contaminação no solo por lixiviado de aterro de lixo urbano. IV Congresso Brasileiro de Geotecnia Ambiental-REGEO, CDRom, 8p., Pernambuco, Brasil.

SELUR e ABLP (2010). Gestão de limpeza urbana - Um investimento para o futuro das cidades. http://www.selurb.com.br/upload/estudo_selur_2010.pdf, 57p.

SILVEIRA, A.M.M. (2004). Estudo do peso específico de resíduos sólidos urbanos. Dissertação de mestrado, 101 p. Universidade Federal do Rio de Janeiro, Rio de Janeiro.

SOUTO, G. D. A. B. (2009). Lixiviado de aterros sanitários brasileiros-estudo de remoção do nitrogênio amoniacal por processo de arraste com ar ("stripping"). Tese de doutorado, 371 p. Escola de Engenharia de São Carlos, São Paulo.

STUERMER, M. M. (2006). Contribuição ao estudo de um solo saprolítico como revestimento impermeabilizante de fundo de aterros de resíduos. Tese de doutorado, 207 p. Escola Politécnica da USP, São Paulo. 
STUDDS, P. G. (1997). The effect of ion valence on the swelling behavior of sodium montmorillonite. Solos e Rochas - vol. 20, nº 1 Abril, 6p., São Paulo, Brasil.

TRIPATHI, K. K. AND VISWANADHAM, B. V. S. (2005). Ascertainment of bentonite content for sand-bentonite liners. Sardinia 2005-Tenth International Waste Management and Landfill Symposium, Proceedings, CDRom, 10p., S. Margherita di Pula, Itália.

VALADÃO, I.C.R.P., ARAÚJO, A.S.F., SILVA, A.J., CASTRO, J.A., RITTER, E.(2007). Modelagem e simulação computacional do transporte de íons inorgânicos em solos compactados e não compactados. IV Congresso Brasileiro de Geotecnia AmbientalREGEO, CDRom, 8p., Pernambuco, Brasil.

VARGAS, M. (1977). Introdução à Mecânica dos solos. MCgraw-Hill do Brasil, Ed. da Universidade de São Paulo, 509 p.

VIDAL, I.G.(2007). Instalação de geomembranas: Recomendações para projeto e cuidados executivos. V Simpósio Brasileiro de Geossintético, 2007, CDRom, 8p., Pernambuco, Brasil. 


\section{ANEXO}


Ensaios Realizados

Material utilizado

Granulometria

Coleta $1 \quad$ Coleta 2

Densidade dos grãos

Coleta 1 Coleta 2

Limites de Atterberg

Coleta $1 \quad$ Coleta 2

Caracterização minerológica

Coleta 2

Caracterização química

Coleta 2

Compactação

Coleta 1 Coleta 2

Permeabilidade à água do solo natural e com as misturas de solo e $2,5 \%, 5 \%$ e $7,5 \%$

Coleta 1

Permeabilidade ao líquido percolado com solo natural e com 5\% de bentonita

Coleta 2

Adensamento do solo natural e com $5 \%$ de bentonita

Coleta 2

Cisalhamento direto do solo natural e com

$5 \%$ de bentonita

\section{Coleta 1}

Expansão

Coleta 2 


Universidade de São Paulo
Escola Superior de Agricultura "Luiz de Queiroz"
Departamento de Ciência do Solo

RESULTADO DE ANÁLISE

\begin{tabular}{lccccccccccccc}
\hline Amostra & $\mathrm{pH} \mathrm{H} 2 \mathrm{O}$ & $\mathrm{pH} \mathrm{KCl}$ & $\mathrm{M} . \mathrm{O}$ & $\mathrm{P}$ & $\mathrm{K}$ & $\mathrm{Ca}$ & $\mathrm{Mg}$ & $\mathrm{Al}$ & $\mathrm{H}+\mathrm{Al}$ & $\mathrm{SB}$ & $\mathrm{T}$ & $\mathrm{V}$ & $\mathrm{m}$ \\
\hline AM 01 & 5,1 & 4,1 & 1 & 2 & 0,7 & 1 & 1 & 5 & 14 & 2,4 & 16,4 & 15 & 68
\end{tabular}

M.O. (g.Kg-1); P (mg.Kg-1); K, Ca, Mg, Al, H+Al, SB, T (mmolc Kg-1); V e m (\%).

Métodos:

pH em água; $\mathrm{pH}$ em KCl; M.O. - dicromato/titulométrico;

$\mathrm{P}, \mathrm{K}, \mathrm{Ca}, \mathrm{Mg}$ - extração pela Resina trocadora de íons:

$\mathrm{Al}$ - extração pelo $\mathrm{KCl} 1 \mathrm{~mol} . \mathrm{L}-1$;

$\mathrm{H}+\mathrm{Al}$ - extração $\mathrm{Ca}(\mathrm{CH} 3 \mathrm{OO}) 2 . \mathrm{H} 2 \mathrm{O}$.

Observações:

Prof. Dr. Luís R. Ferracciú Alleoni

Amostra coletada pelo interessado; 